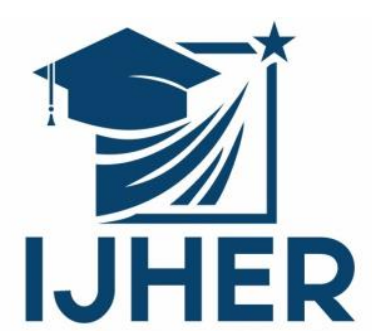

International Journal of Humanities and Educational Research

Volume 2, Issue 4, December 2020, p.61-93

İstanbul / Türkiye

\title{
THE TECHNIQUES OF SELECTION AND AESTHETICS OF ECART IN THE NOBLE QUR'AN - SEMANTIC STUDY
}

http://dx.doi.org/10.47832/2757-5403.4-2.4

ISSN: $2757-5403$

Article Information

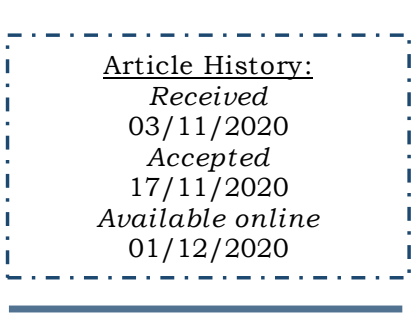

This article has been scanned by iThenticat No plagiarism detected

Copyright $($ C Published by Rimak Journal, www.rimakjournal.com

Rimar Academy, Fatih, Istanbul, 34093 Turkey All rights reserved
Keywords: QUR'AN, language, Quranic words

\footnotetext{
${ }^{1}$ Assist. Prof. Dr. Ahmed Ali Niimaa AL-ZUBAIDY, College of Arts, Iraqia University, Iraq. mujamart@gmail.com

\section{IJHER}

International Journal of Humanities and Educational Research

Volume 2, Issue 4, December 2020, p.61-93
} 


\title{
فنيات الاختيار وجماليات العدول في القرآن الكريم - دراسة دلالية
}

\author{
2 أحمد الزبيدي
}

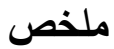

تطرق البحث إلى بيان أن القرآن تعبير بياني مقصود؛ أي إن كل كلمة، وكل حرف فيه وضع وضعاً

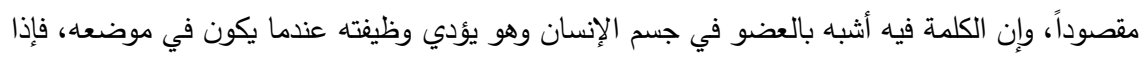

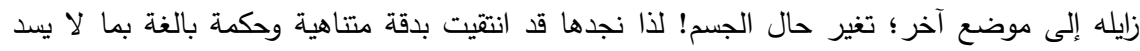

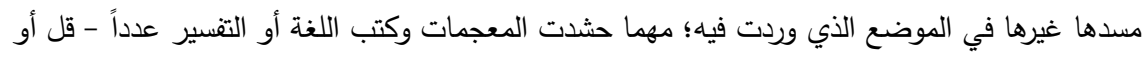
كثر - من الكلمات البديلة المقاربة، وأن اللفظ والمعنى فيه مرادان معاً؛ فلا يطغى أحدها على الكيلى الآخر؛

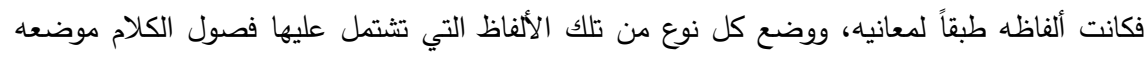

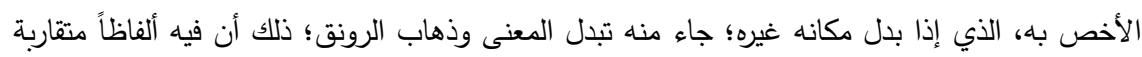

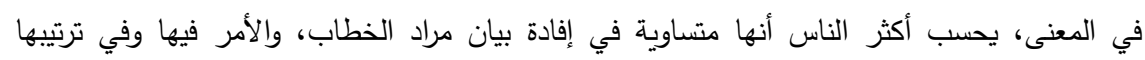

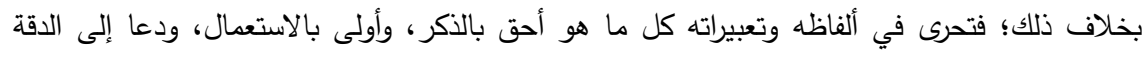

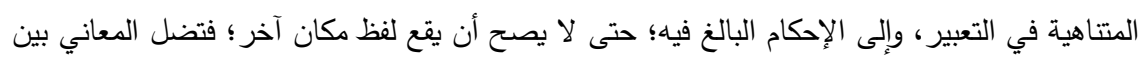

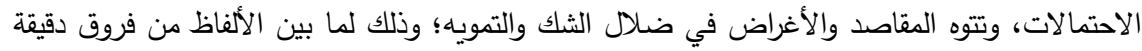
في دلالاتها. الكلمات المفتاحية: ألفاظ، معاني، دلالة، بلاغة، اختيار ، عدول، ترادف، تقارب، تبادل، تفسير، جمال، فن، سر.
\end{abstract}

المقدمة

الحمد لله رب العالمين، أنزل خير كتبه على خير رسله، وجعله بلسان عربي مبين، وصلوات ربي وسلامه العها

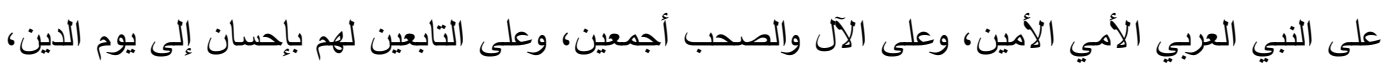

فكل كتاب يرثُّ كلامه بكثرة البحث فيه، وتذوي الأفكار منه، وينضب عطاؤه، إلا هذا الكتاب الكريم، كلما

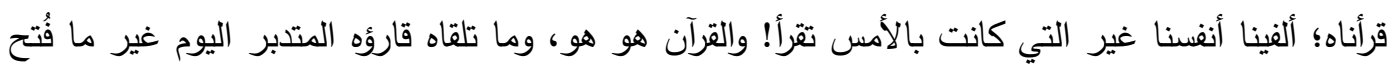
له منه بالأمس، وإنا لا نجد غيره يمنحنا هذا وأكثر من هذا، ويؤتينا كل يوم تصوراً جديداً؛ حتى لكأننا نقرأ

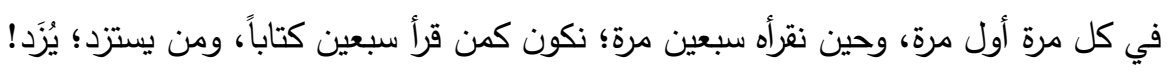

2 أستاذ مساعد دكتور : أحمد علي نعمة الزبيدي، كلية الآداب (قسم علوم القرآن)، الجامعة العراقية، العراق. mujamart@gmail.com

\section{IJHER}

International Journal of Humanities and Educational Research

Volume 2, Issue 4, December 2020, p.61-93 
إنّ القرآن الكريم كنز يستقتحه وينقب عنه أهل كل عصر بأدواتهم ليغترفوا منه ما تسنى لهم من معينه، وهو

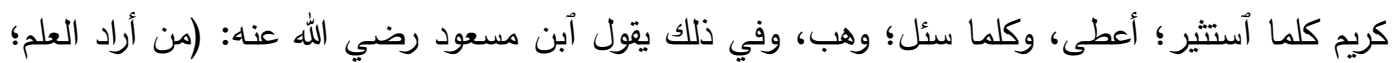

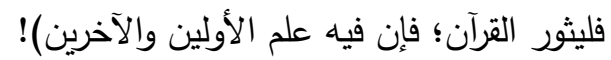
ومن وجوه إعجازه: أن يظل مشغلة العلماء والدارسين جيلاً بعد جيل، ثم يبقى أبداً رحب الآفاق والمدى، سخي المورد والمأتى؛ فما أنفك العلماء يُشمّرِون عن سواعد الجد والاجتهاد بتتميق العبارات ووشي الأسفار وتأليف العلوم فيه؛ في سعي منهم لبلوغ معانيه وأسراره، وإدناء البعيد منها، وتجلية المبهم، وفتح المستغلق، وكل منهم يبذل من الجهد ما وسعه، وسيظلون في فلكه دائرين، وعلى دربه سائرين، ومن شواطئه لا أغواره

مغترفين!

لقد يمَّم العلماء صوب هذا الكتاب الكريم بحثاً وتأملاً، ولم يدخروا في ذلك جهداً إلا بذلوه ولا سبيلاً إلا سلكوها، ولكوني من خلف أولئك السلف؛ فقد آليت على نفسي الالتحاق بالركب بغية إدراكه؛ فحططت رحالي على واحدة من أخصب واحاته لأتملَّى في مرآها، وأتتسم عبير شذاها، وأتقلب بين مائها ومرعاها؛

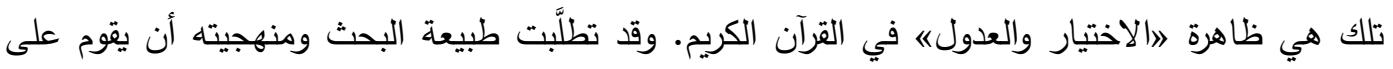
مبحثين وخاتمة تكتنف أهم النتائج التي توصلت إليها، يتلوها ثبت بأهم المظان التي أفدت منها في في إثراء

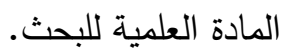

\section{المبحث الأول: القرآن تعبير بياني مقصود}

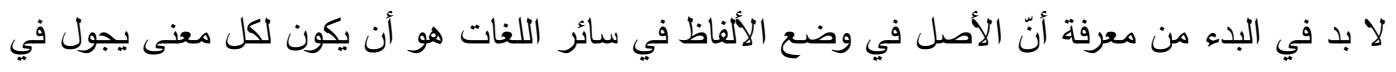

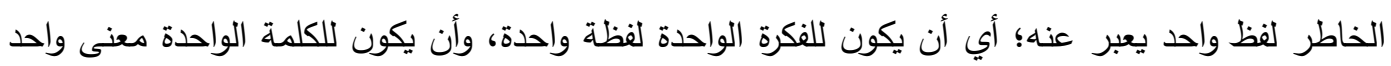
أيضاً، وأن الخلط والاضطراب يتأتى من مجرد أن يوجد لفظان فأكثر لمعنى واحد أو متقارب، أو معنيان فأكثر للفظ واحد؛ وإن كانت اللغات جميعاً لا تتجو من هذه الإصابة؛ نتيجة الظروف الناب الناشئة في اللغات، والتي تؤدي بدورها إلى تعدد الألفاظ لمعنى واحد أو متقارب، أو تعدد المعاني للفظ واحد الفئ.

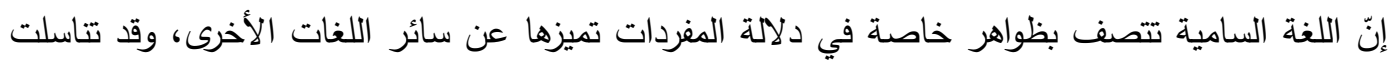

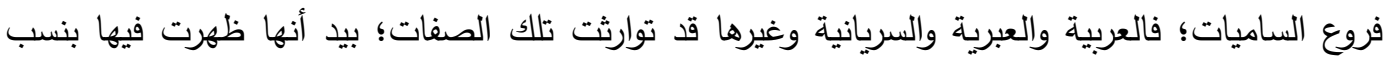
متفاوتة! فمن المعروف أن ثمة أنواعاً ثلاثة من دلالات الألفاظ، منها: أن يختلف اللفظ ويتفق المعنى؛ ولكن وارتي

دلالتها جميعاً تكون واحدة، ومنها أن يتفق اللفظ ويختلف المعنى، ومنها أن يتفقا معاً، أو أن يختلفا معاًُ،

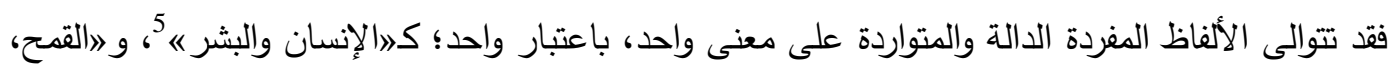

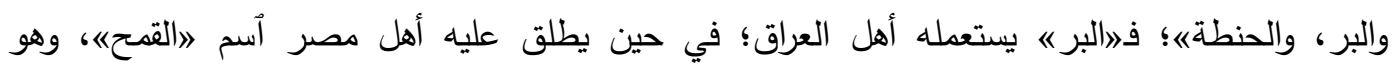

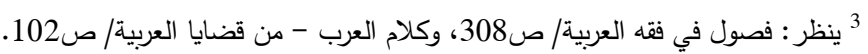

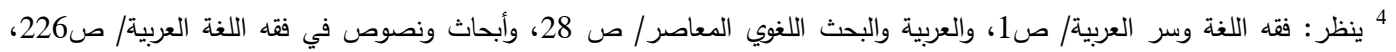

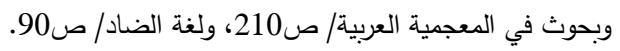
5

\section{IJHER}

International Journal of Humanities and Educational Research

Volume 2, Issue 4, December 2020, p.61-93 
》الحنطة" عند أهل مكة6. ويعد المبرد من كلام العرب: (أختلاف اللفظين والمعنى واحد؛ مثل: 》ظننت

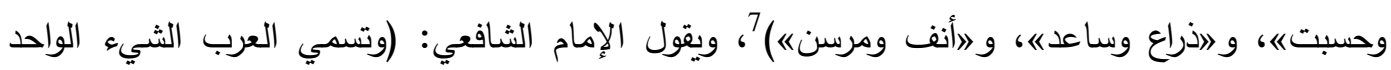

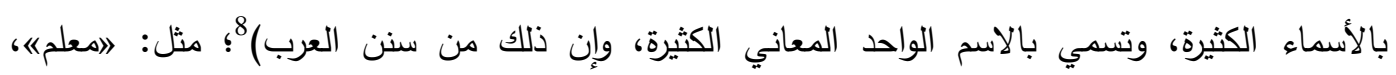

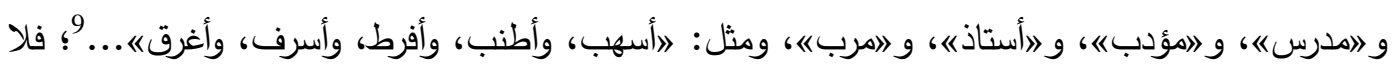

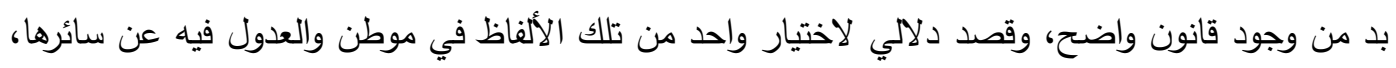

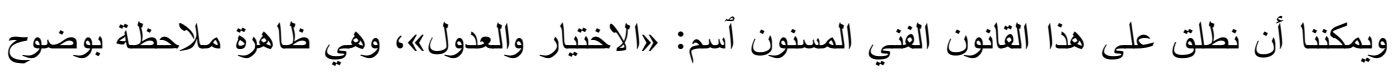
في لغة العرب عموماً، وفي لغة القرآن على نحو خاص. وإزاء تلك الظاهرة اللغوية الفنية؛ ما كان للعلماء المتخصصين والدراسات والكتب والأبحاث المعدة بهذا

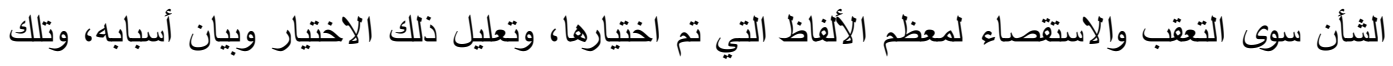
التي تم العدول عنها، وتعليل ذلك العدول وبيان أسبابه؛ إن لم يكن هذا التعقب وذاك الاستقصاء قد طال الألفاظ جميعاً؛ ولا سيما القرآنية منها 10. لقد ألفينا ثلة من العلماء المتخصصين قدامى ومحدثين يلتمسون فروقاً دقيقة بين معاني الكلمات؛ الأمر الذي حدا ببعضهم إلى القول بامتياز اللغة العربية بوفرة كلماتها وتعدد ألفاظها في المعنى الواحد أو المعاني لئي المتقاربة، وليس معنى ذلك أن هذه الكلمات كلها تدل على هذا المعنى الواحد بلا فروق يلاحظها المتكلم أو

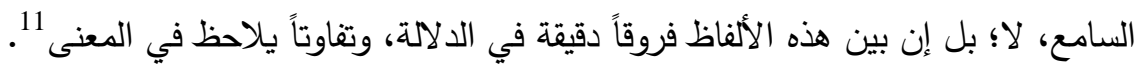

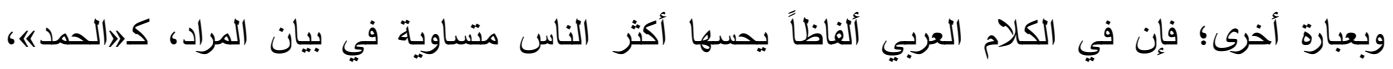

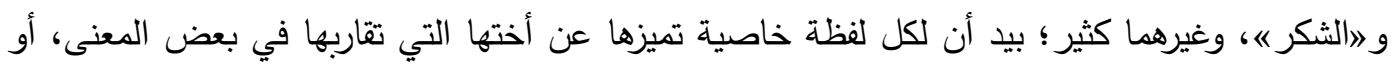
تشترك معها في بعض الدلالة'، وسيأتي بيان الفرق بينهما في معرض تناولنا للأمثلة والثواهد التفصيلية في المبحث التالي بإذن الله. وقد عني علماؤنا الأجلاء ببيان الفروق بين الكلمات المتقاربة المعنى، والتعابير المتشابهة الدلالة، ومن بين هؤلاء: الخطابي، الذي يؤكد أن من دقائق التركيب وأسس البلاغة: (وضع كل نوع من الألفاظ التي تشتمل

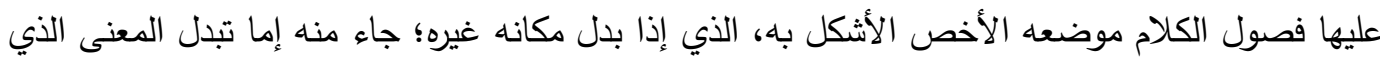
يكون منه فساد الكلام، وإما ذهاب الرونق الذي يكون معه سقوط البلاغة؛ ذلك أن في الكلام ألفاظاً متقاربة

$$
\begin{aligned}
& 6 \text { ينظر : علم أصول الفقه/ ص32. }
\end{aligned}
$$

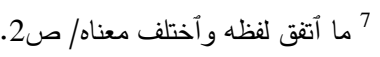

$$
\begin{aligned}
& 8 \text { الرسالة/ ص32. }
\end{aligned}
$$

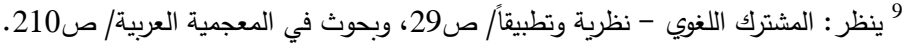

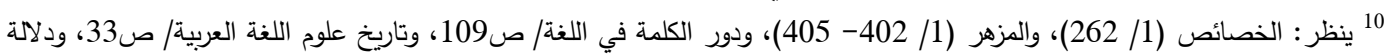

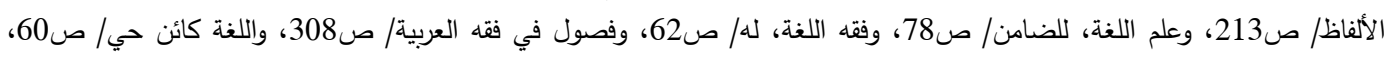

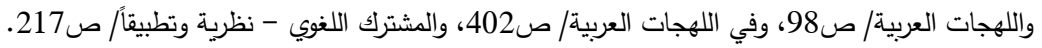

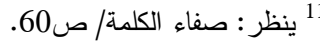

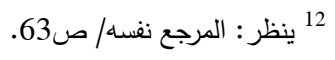

\section{IJHER}

International Journal of Humanities and Educational Research

Volume 2, Issue 4, December 2020, p.61-93 


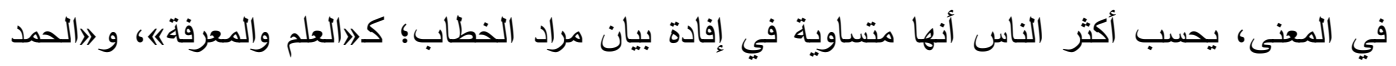

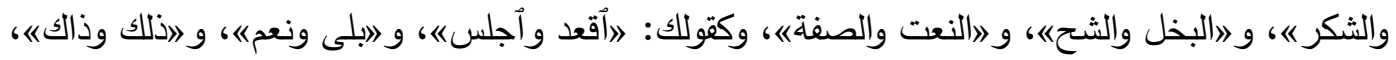

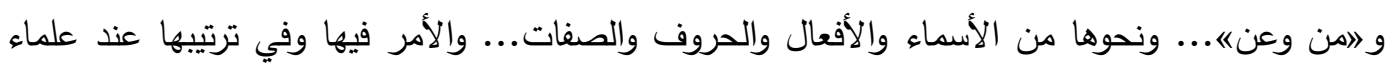

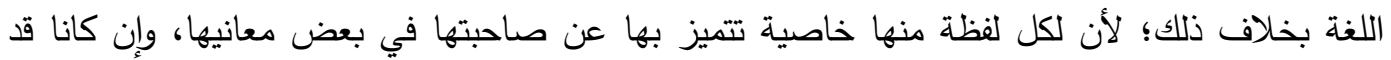

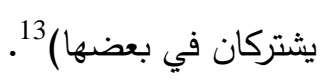
ولأبي هلال العسكري كتاب في ذلك سماه: 》الفروق اللغويةه، وكذا الحال بالنسبة لأبي علي الفارسي، والمبرد، وأبي منصور الثعالبي، في الفقه اللغةه، وأبن فارس في 》الصاحبي في فقه اللغةه.... إلخ؛

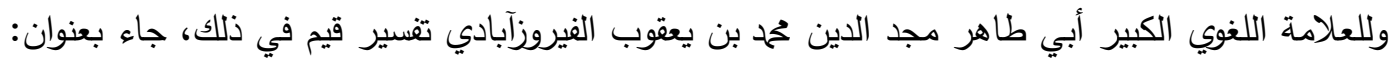

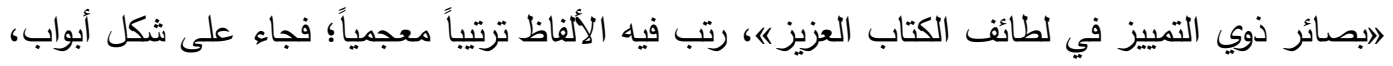

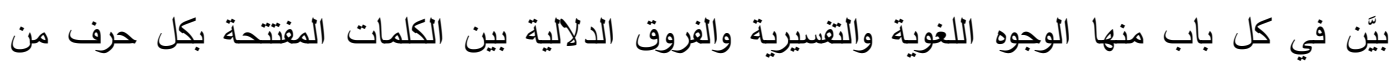

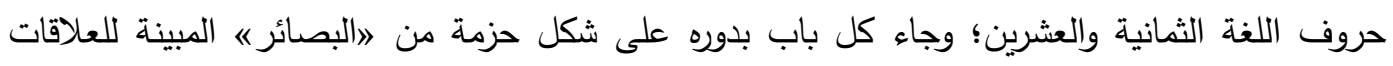
اللغوية الأسرية لألفاظ ذلك 》البابه؛ جاء في 》المزهر ه أن الشيخ القاضي أبا بكر آبن العربي حكى بسنده عن أبي علي الفارسي، قال: كنت

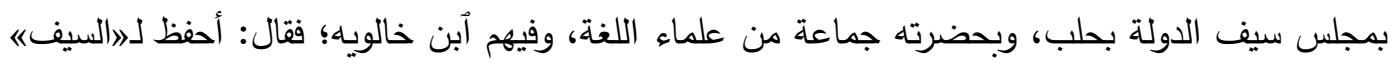

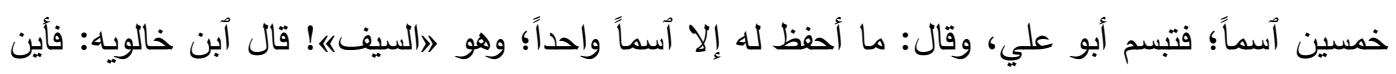

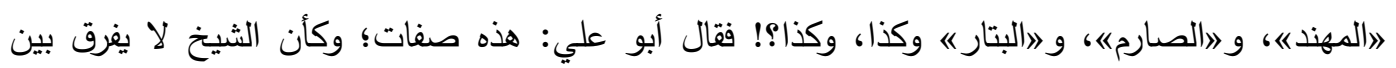
الاسم والصفة 14 الصة

والحق أن أكثر الألفاظ التي يقال أنها متواطئة على معنى واحد هي - في الواقع - ليست كذلك؛ فإذا ما أنعمنا النظر فيها؛ تبين لنا أن كل لفظ منها يدل على معنى يختلف - ولو قليلاً - عما يدل عليه الآخر . فإذا أخذنا - على سبيل المثال - لفظي 》الثك والريبه؛ نجد أن الجمهور يفسرون أحدها بالآخر؛ فيقولون في تفسير أمثال قوله تعالى: (ذلك الكتاب لا ريب فيه) [البقرة/2]، و (إنهم كانوا في شك مريب)

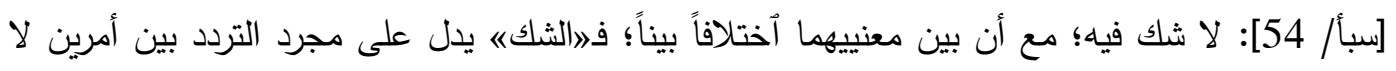

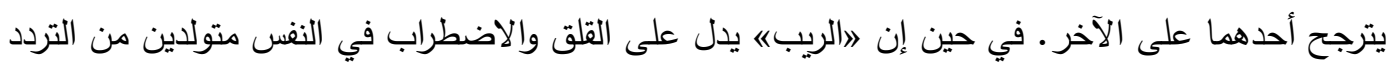
الذي يدل عليه الثك. ف»الريبه: شك مصحوب بقلق واُضطراب؛ ومن ثم يقال: هو في شك مريب؛ أي:

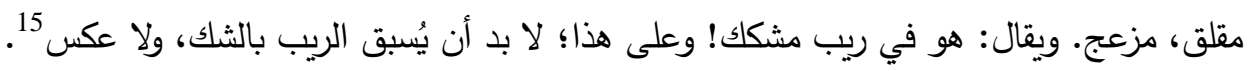
وما قيل عن 》الثك والريبه يقال كذلك عن 》القعود والجلوس، من من حيث العموم؛ إذ إنها من الألفاظ التي

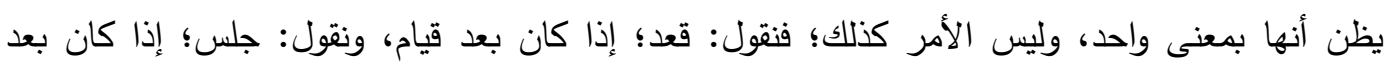

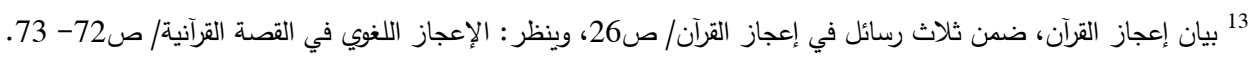

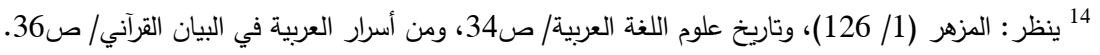

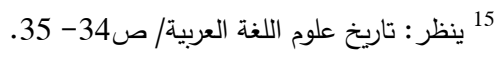

\section{IJHER}

International Journal of Humanities and Educational Research

Volume 2, Issue 4, December 2020, p.61-93 
أضطجاع 16؛ فالقعود في اللغة: ضد القيام، يقال: كان واقفاً؛ فقعد، وكان مضطجعاً؛ فجلس 17. والذين يقولون بظاهرة 》الاختيار 《 لبعض الألفاظ في مواطن، و العدوله عن بعضها في مواطن أخرى؛ يفرقون

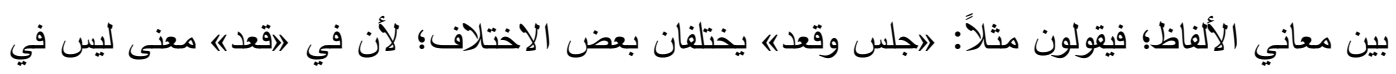

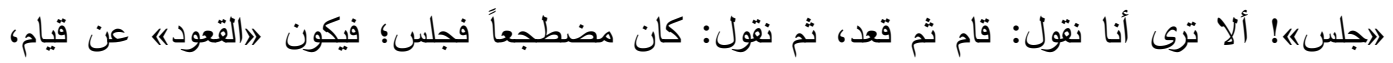
و »الجلوس" عن حالة دون الجلوس 18؛ وبذا كانت قضية 》الاختيار والعدوله والعوامل الدلالية الكامنة وراءها جزءاً مهماً من شغل العلماء الثاغل قديماً وحديثاً. كان - فيما تقدم - خلاصة موجزة عن تللك الظاهرة؛ فلا يوجد في القرآن تطابق معنوي تام؛ بل تلب تقارب وتكامل في المعنى؛ وذلك لسبب من الخطورة بمكان؛ وهو أن القرآن الحكيم - كما سنأتي إلى ذكره لاحقاً

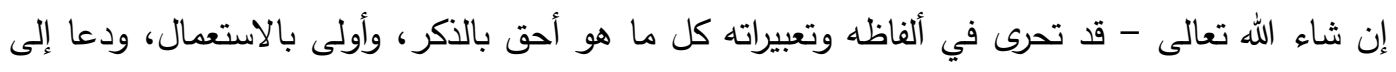

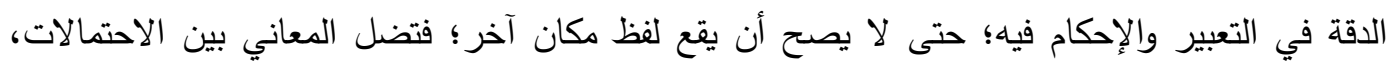
وتتوه المقاصد والأغراض في ضلال الثك والتمويه؛ وذلك لما بين الألفاظ من فروق دقيقة في دلالاتها! فيستخدم كل كلمة بدقة متتاهية؛ بحيث تؤدي معناها المراد في إحكام شديد، يكاد السامع يؤمن بأن هذا ودأ

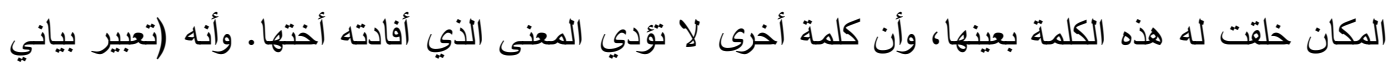
مقصود؛ أي أن كل كلمة، وكل حرف فيه وضع وضعاً مقصوداً) 19، وأن الكلمة فيه أشبه بالعضو في جسم الته الإنسان وهو يؤدي وظيفته عندما يكون في موضعه، فإذا زايله إلى آخر ؛ تغير حال الجسم، وآ وأعتل، واُختل

توازنه؛

بهذا المقياس الحكيم، والقسطاس المستقيم كانت كلمات القرآن الكريم طبقاً لمعانيه؛ بحيث أسترعت ألفاظه وفصاحته أنظار العلماء! وهكذا دائماً: لكل مقام مقال في التعبير القرآني. ومن الأمثلة لتلك الظاهرة في القرآن الكريم الآتي 20. 1. الإيثار والتفضيل《: (قالوا تالله لقد آثرك الله علينا وإن كنا لخاطئين) [يوسف/ 91]، (وأني فضلتكم على العالمين) [البقرة/ 47]

2. الحضور والمجيء《: (حضر أحدكم الموت) [البقرة/ 180]، (جاء أحدكم الموت) [الأنعام/ 61].

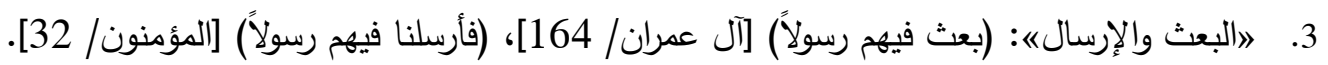
4. البلد والقريةه: (لا أقسم بهذا البلد * وأنت حل بهذا البلد) [البلد/ 1-2]، (وكأين من قرية هي أشد قوة من قريتك التي أخرجتك) [تحم/ 13].

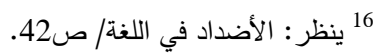

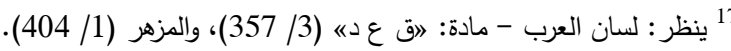

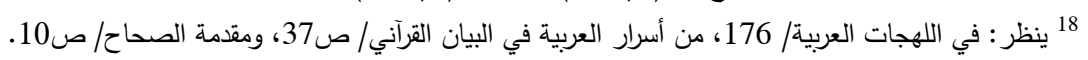

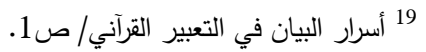

$$
\begin{aligned}
& 20 \text { ينظر: الإنقان في علوم القرآن (1/ 310)، والتنسير والمفنسرون (1/ 279)، وقواعد التنسير - جمعاً ودراسة (1/ 461- 470)، وفي }
\end{aligned}
$$

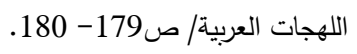

\section{IJHER}

International Journal of Humanities and Educational Research

Volume 2, Issue 4, December 2020, p.61-93 
5. ״النار والجحيم): (ومأواهم النار وبئس مثوى الظالمين) [آل عمران/ 151]، (فإن الجحيم هي المأوى])

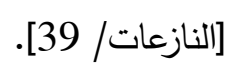

6. 》الأسى والحزن《: (فلا تأس على القوم الفاسقين) [المائدة/ 26]، (ولا تحزن عليهم) [النحل/ 127]. 7.

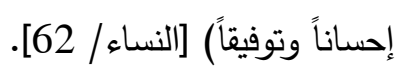

8. 》البارئ والخالق): (فتوبوا إلى بارئكم) [البقرة/ 54]، (قل الله خالق كل شيء) [الرعد/ 16].

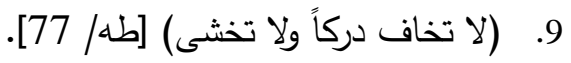

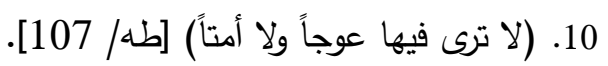
11. (فلا يخاف ظلماً ولا هضماً) [طه/ 10 1112].

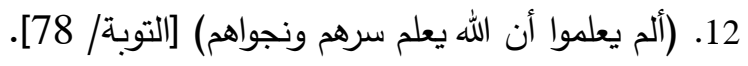

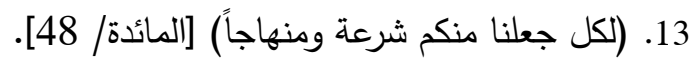

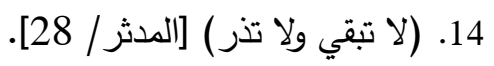

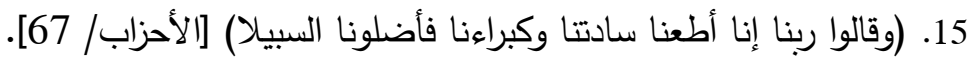

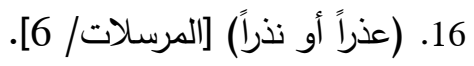

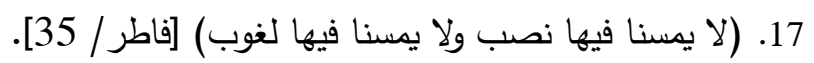
18. (ويل لكل همزة لمزة) [الهمزة/ 17]. 19. (فأغرينا بينهم العداوة والبغضاء إلى يوم القيامة) [المائدة/ 14].

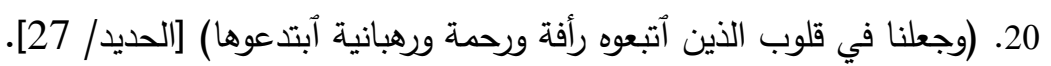
21. (والصابرين في البأساء والضراء) [البقرة/ 177].

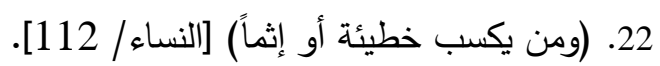
23. (وليعفوا وليصفحوا) [النور / 22]. 24. (إن الله العفو غفور) [الحج/ 60.

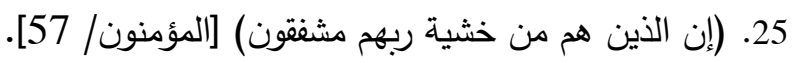
26. (وما الحياة الدنيا إلا لعب ولهو) [الأنعام/ 32 32].

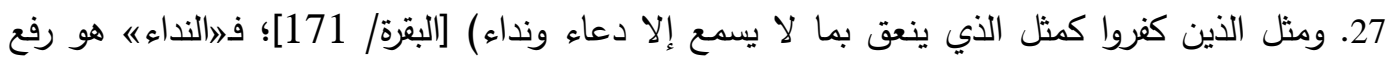

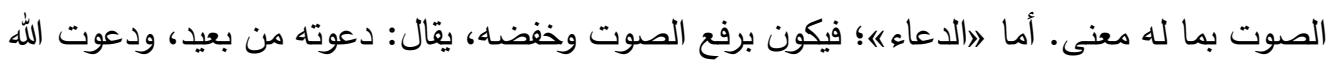
في نفسي، ولا يقال: ناديته في نفسي.

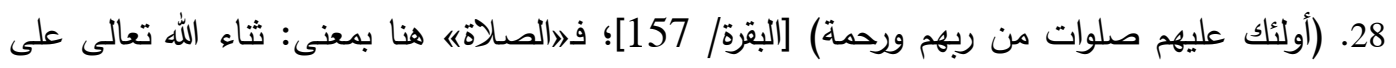

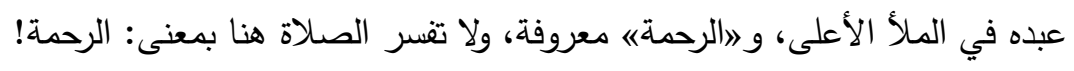

\section{IJHER}


29. (فإن طبن لكم عن شيء منه نفساً فكلوه هنيئاً مريئًا) [النساء/ 4]؛ ف»الهنيء ): الخالص من كل كدر،

و 》المريء«: المحمود العاقبة.

30. (فما وهنوا لما أصابهم في سبيل الله وما ضعفوا وما آستكانوا) [آل عمران/ 146]؛ فهالوهن《: أن يفعل الإنسان فعل الضعيف، أو هو أنكسار الحد، والخوف ونحوه، و 》الضعف): نقصان القوة. أما

》الاستكانة《؛ فهي إظهار الضعف!

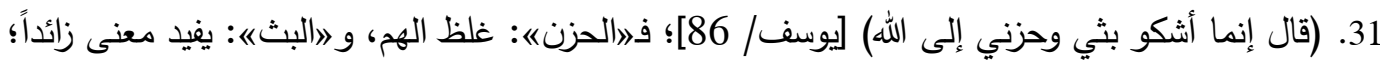

وهو أنه ينبث ولا ينكتم؛ من قولك: أبثته ما عندي، وبثثته؛ إذا أعلمته إياه؛

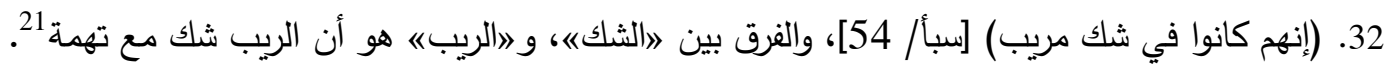

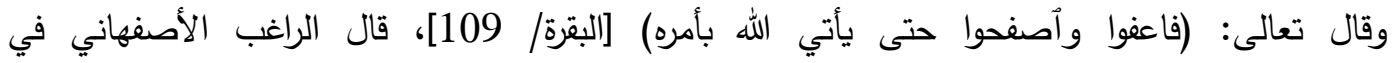

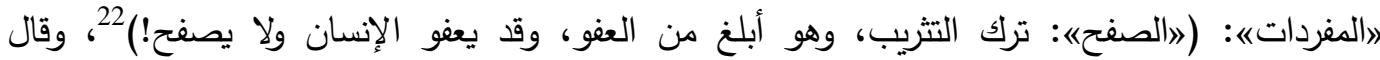

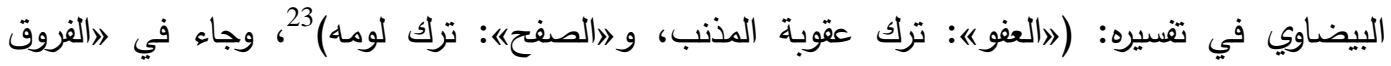

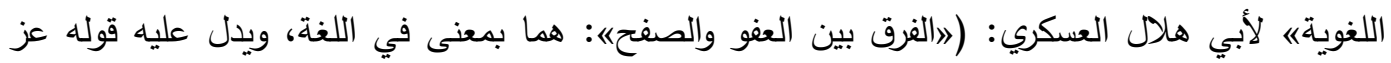
وجل: (فاعفوا وأصفحوا) ترقياً في الأمر بمكارم الأخلاق من الحسن إلى الأحسن، ومن الفضل إلى لهن

الأفضل)

يقول الدكتور صبحي الصالح: (لقد أتاح لهذه اللغة طول اُحتكاكها باللهجات العربية الأخرى آقتباس

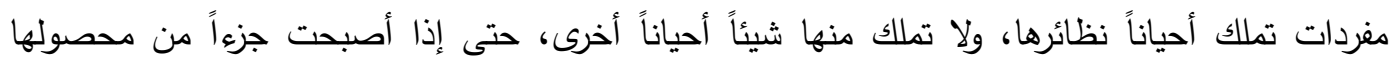

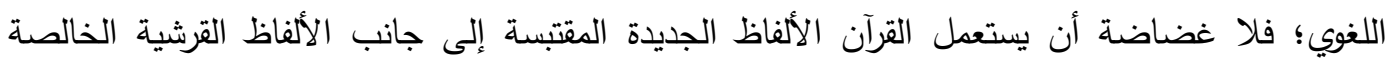

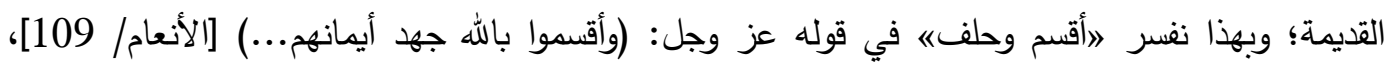

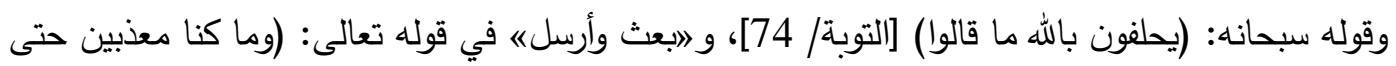

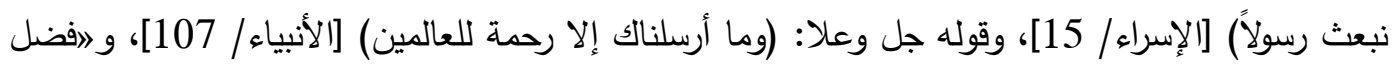
وآثر ه في قوله سبحانه: (تلك الرسل فضلنا بعضهم على بعض) [البقرة/ 253]، وقوله تعالى على لسان

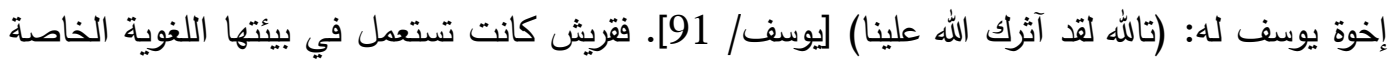
أحد اللفظين في هذه الأمثلة الثلاثة؛ وإنما أكتسبت اللفظ الآخر من أحتكاكها بلهجة أخرى لها بيئتها اللغوية

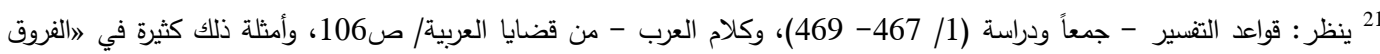
اللغوية، للثايع)، ينظر : ص213 (213 إلى آخر الكتاب. . $372 / 1)^{22}$ 23 أنوار التنزيل وأسرار التأويل (1/ / 148 (148).

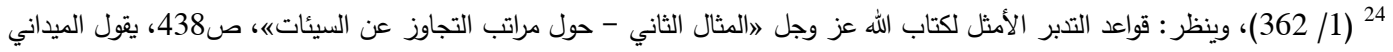

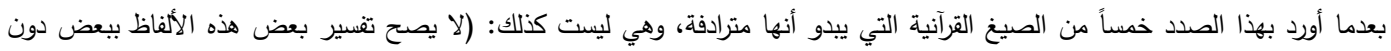
تجوز ؛ إذ هي ليست مترادفات؛ إنما هي مراتب، بعضها أعلى من بعض، وبعضها لهنها أخص من بعض؛ لما فيها من معان زائدة). 
المستقلة! وهكذا لم نجد مناصاً من الاعتراف بالفروق بين الألفاظ؛ ولكن هذه الفروق - على ما يبدو لنا -

تتوسيت فيما بعد، وأصبح من حق اللغة التي ضمتها إليها أن تعدها ملكاً لها، ودليلاً على شرائها)

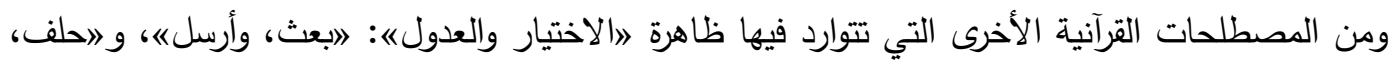

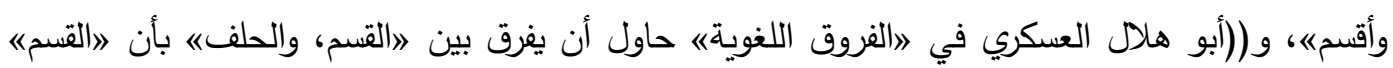

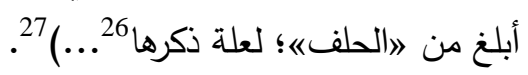
صفوة القول في تلك الألفاظ والتراكيب القرآنية المتقاربة التي يتوهم فيها التطابق المعنوي التام وهي ليست

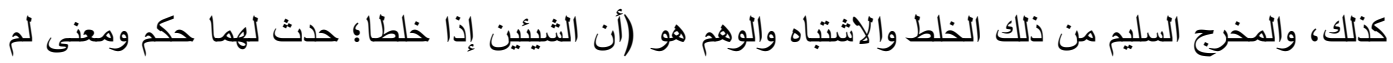

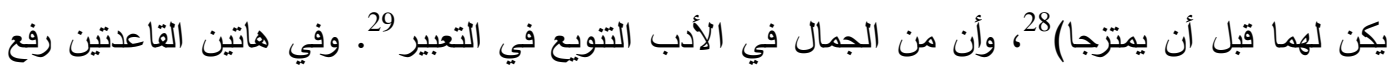
لتوهم التكرار حين العطف؛ لأنّ التركيب يحدث معنى زائداً. وإذا كانت كثرة الحروف تثيد زيادة المعنى؛

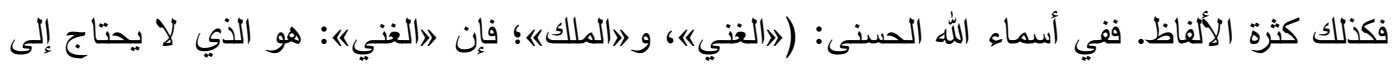

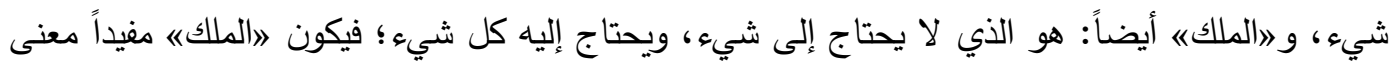

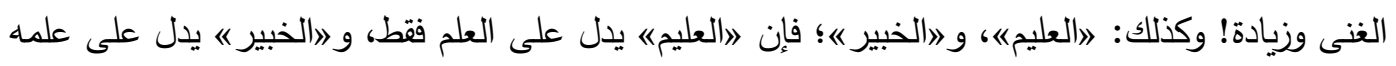

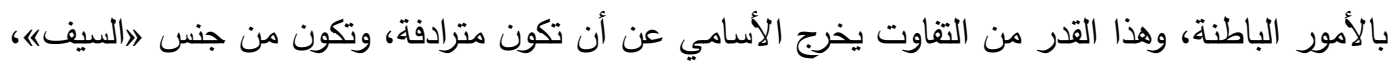

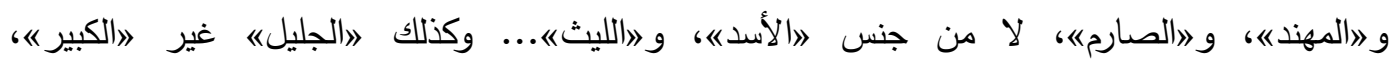

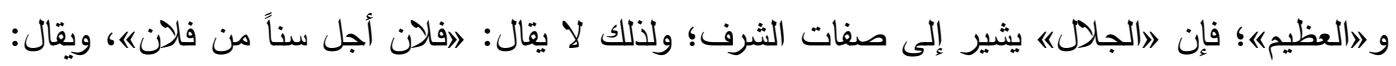

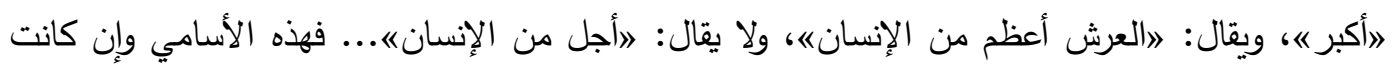

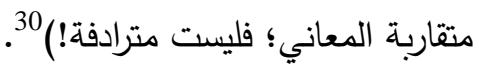

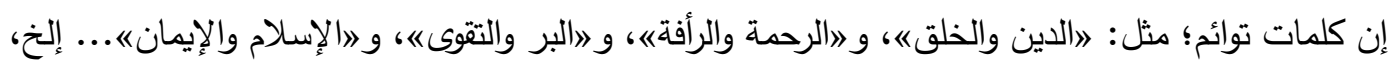

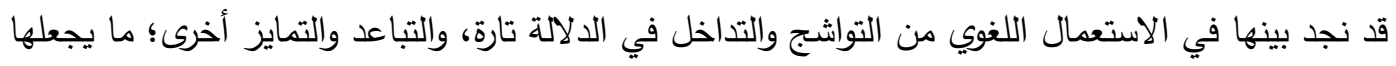

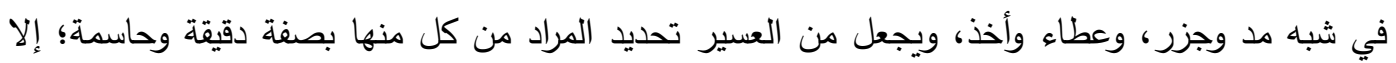

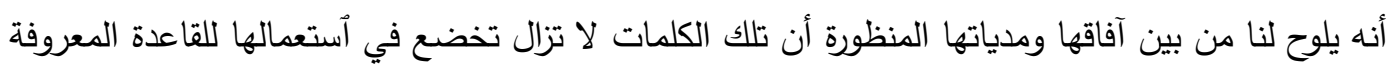

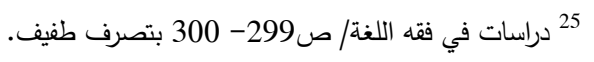
26 تلك العلة هي قوله: (لأن معنى قولنا: 》أقسم باللهه أنه صار ذا قسم بالله، والقسم: النصيب. والمراد أن الذي أقسم عليه من المال وغيره قد

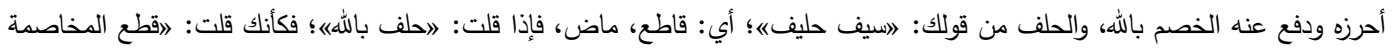

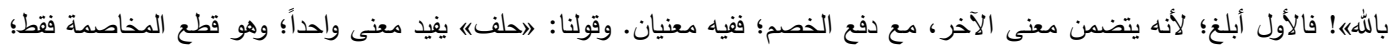

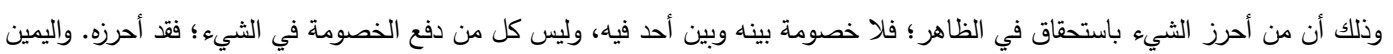

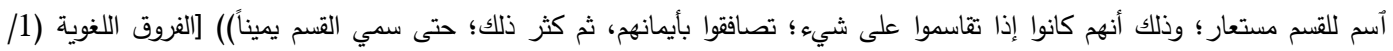

27 فصول في فقه العربية/ ص317.

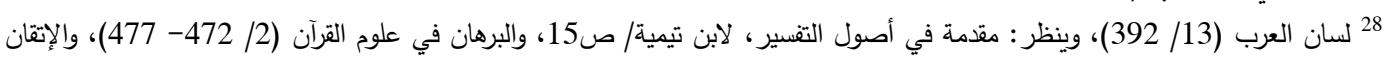

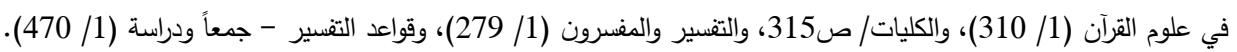

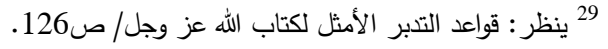

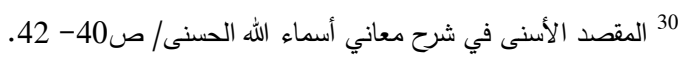

\section{IJHER}

International Journal of Humanities and Educational Research

Volume 2, Issue 4, December 2020, p.61-93 
في الكلمات العربية المنحدرة من أسرة واحدة. وفي تتاسب أخاذ، فيه من الطرد والعكس معاً بنت علاقاتها

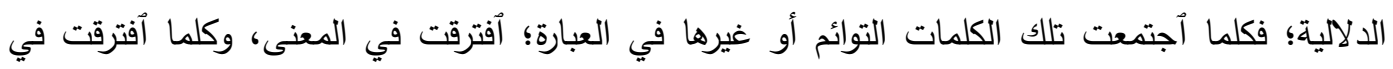

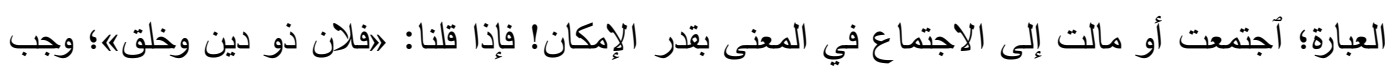

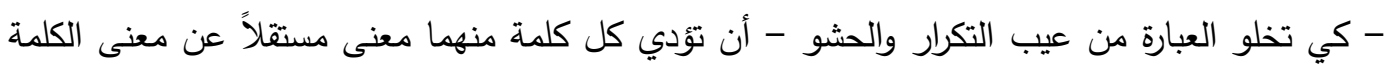
الأخرى؛ فيختص 》الدينه بالإيمان والتقوى الخاصة؛ بمعنى: القيام بفرائض العبادة. في حين يكون معنى

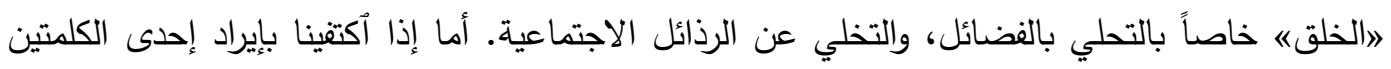

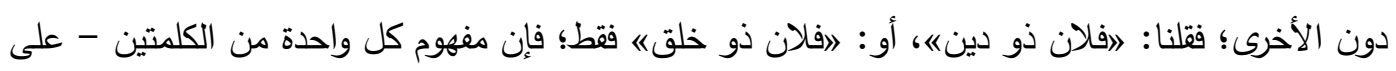

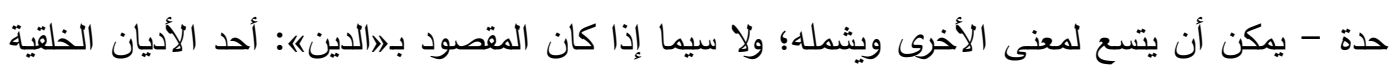
المعروفة، وكان المقصود بهالأخلاقه: الأخلاق المتواضع عليها؛ وهي الجامعة للحقوق الإلهية والإنسانية معاً فو(مهما أمكن إبعاد فكرة 》الترادف) عن الكلمات القرآنية؛ فهو الأحق بأن يكون المنهج لدى تدبر القرآن

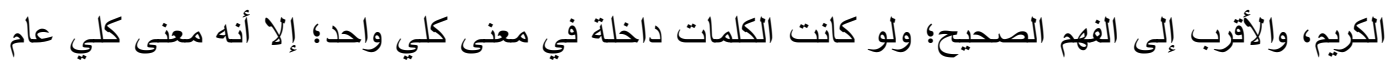

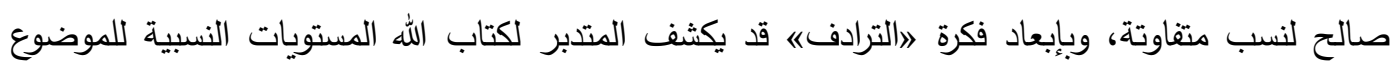
الواحد، والدرجات التي يقصد الإثارة إليها. وقد يظهر له بعض أغراض تكرير الفكرة في مواضع مختلفة.

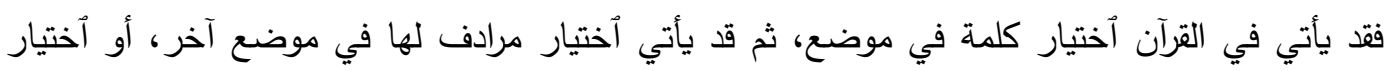

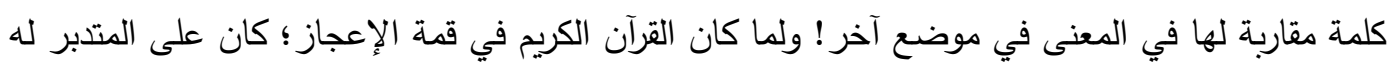

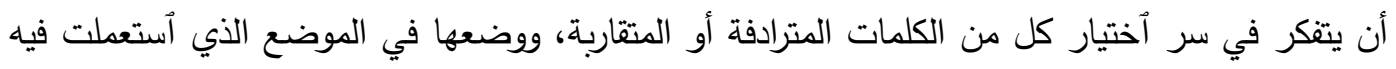

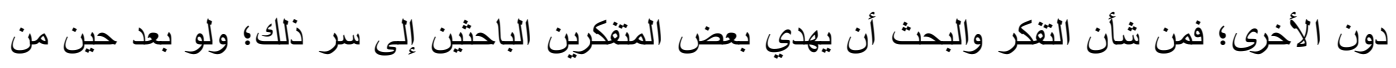
الدهر)

لقد كان القرآن الكريم في ذلك المثل الأعلى الذي يحتذى به؛ إذ فرق بين المترادفات وفصل بينها بما لا

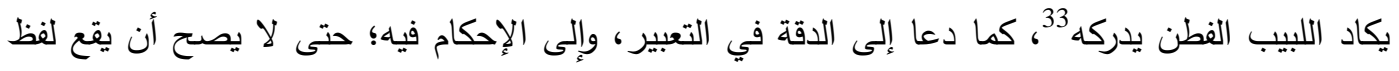

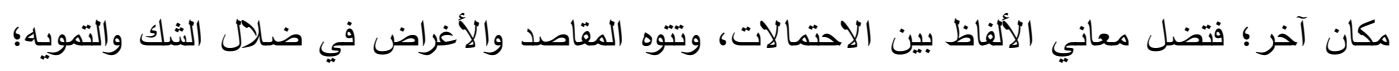
فقال يَّة: (قالت الأعراب آمنا قل لم تئمنوا ولكن قولوا أسلمنا ولما يدخل الإيمان في قلوبكم) [الحجرات/

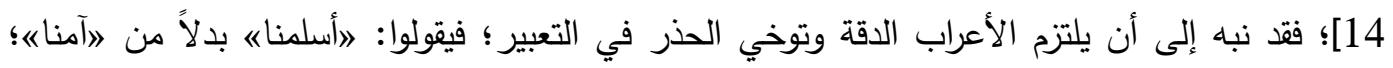

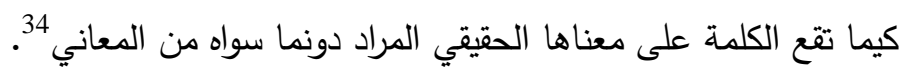

31 ينظر : الدين - بحوث ممهدة لدراسة الأديان والدذاهب/ ص55- 58، والأديان الوضعية في مصادرها المقسة وموقف الإنسلام منها/

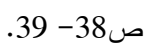
32 قواعد التتبر الأمثل لكتاب الله عز وجل/ صل ص435.

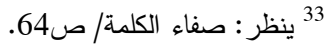
34

\section{IJHER}

International Journal of Humanities and Educational Research

Volume 2, Issue 4, December 2020, p.61-93 


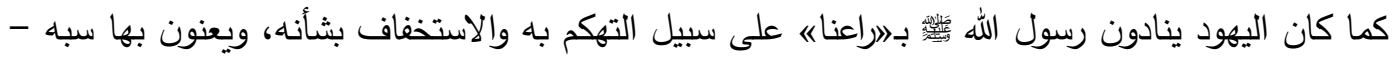

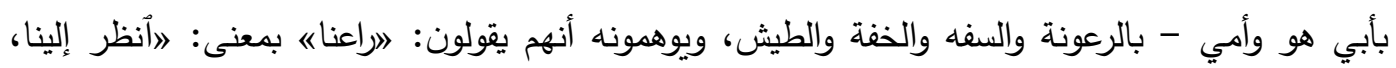
وآرفق بنا، وتمهل معنا، وتأن في أمرناه! يقول عز جل مسجلاً عليهم ذلك: (من الذين هادوا يحرفون الكلم

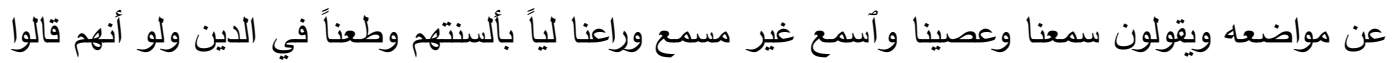

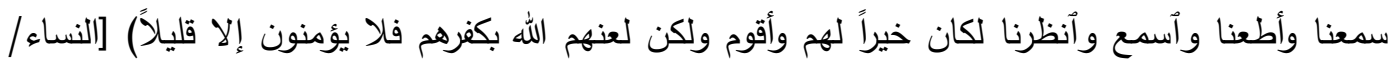

وتجنباً لهذا اللبس والخلط في التعبير؛ فقد نهى القرآن الكريم المؤمنين عن مخاطبة الرسول بها، وأن يبتعدوا عن هذا اللفظ الذي يتخذه اليهود ذريعة، وأن يربأوا بأنفسهم عنه، وأمرهم الله سبحانه أن يحلوا محله بديله في المعنى، الذي لا يملك السفهاء تحريفه وإمالته؛ كي يُفوِّتوا على اليهود غرضهم الخبيث؛ فنقال جلا

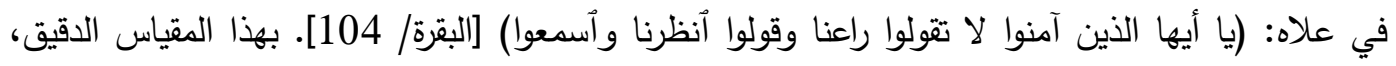

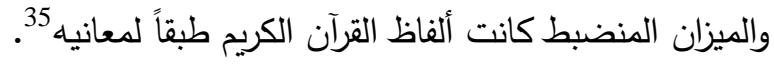
ذلك أن (من أخطر وسائل التجهيل المعار: تعدد الغموض في المعاني، وفي دلالات الألفاظ المستخدمة

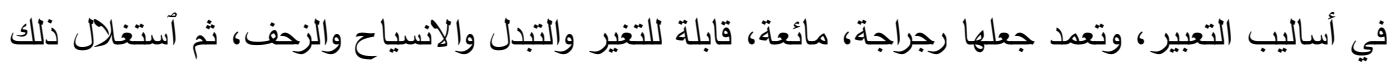

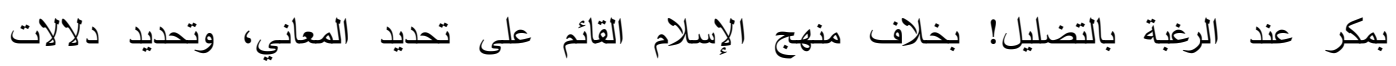

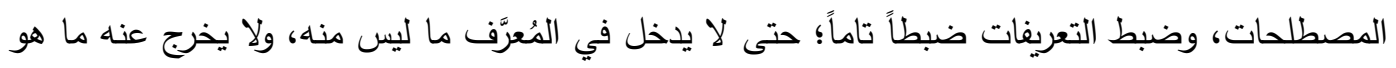
منه! ويشترط علماء المسلمين في التعريف أن يكون جامعاً مانعاً؛ أي: جامعاً لكل عناصر المُعرَّف داخل ماتل التعريف، مانعاً من دخول ما ليس منه فئه فئه

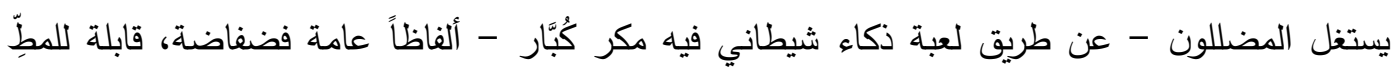

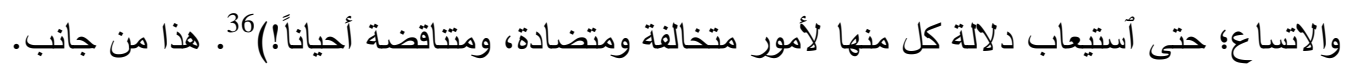
ومن جانب آخر؛ فقد كان لهذا الكتاب المجيد أثره البالغ في اللغة العربية بشتى ألوانها وأفنانها، ومن جميع

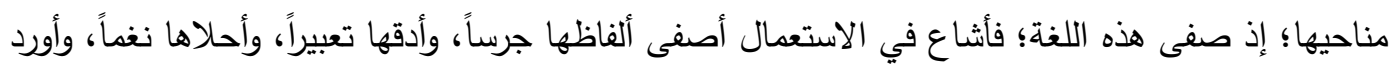
كل لفظة في مكانها المناسب ببراعة فائقة، وآلتزم الدقة في مراعاة دلالة الألفاظ، وإيرادها مواردها بطريقة

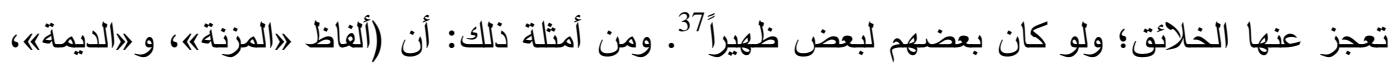
و 》البعاثه تدل على معنى واحد؛ وهي صفة المطر ؛ لكننا نرى أن القرآن لم يستعمل إلا اللفظ الأول؛ لأنه

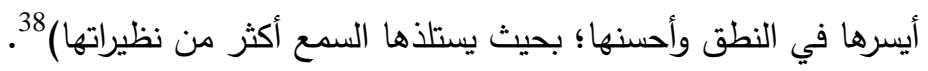

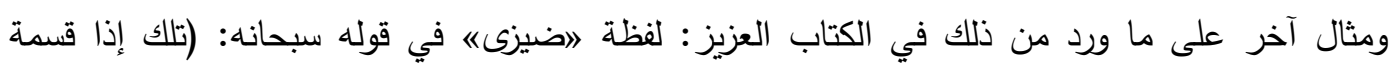
ضيزى) [النجم/22]؛ فمع غرابة تلك اللفظة - بل هي من أغرب ما فيه - ؛ فإن حسنها في موقعها منه فئه

$$
\begin{aligned}
& 35 \text { ينظر : المرجع السابق/ص9 صوب. } \\
& 36 \text { كواشف زيوف في الدذاهب الفكرية المعاصرة/ص219. ص219. }
\end{aligned}
$$

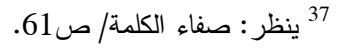

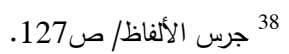

\section{IJHER}

International Journal of Humanities and Educational Research

Volume 2, Issue 4, December 2020, p.61-93 
في نظم الكلام من أغرب الحسن وأعجبه؛ بحيث لا يسد مسدها أي لفظ آخر؛ فغرابتها اللفظية متتاسبة مع غرابة أدعاء أولئك السفهاء ونسبتهم ما يكرهون - البنات أو الإناث - لله جل شأنه! ولو أننا أدرنا اللغة

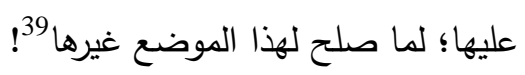
وقد ألمح الجاحظ إلى ذلك بقوله: (وقد يستخف الناس ألفاظاً ويستعملونها، وغيرها أحق بذلك منها! ألا ترى أن الله سبحانه لم يذكر في القرآن »الجوعه إلا في موضع العقاب، أو في موضع الفقر المدقع والعجز

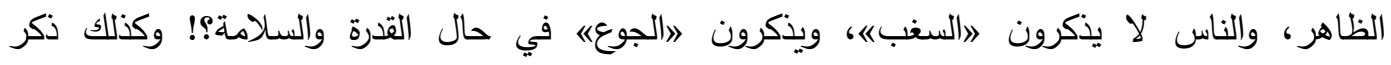

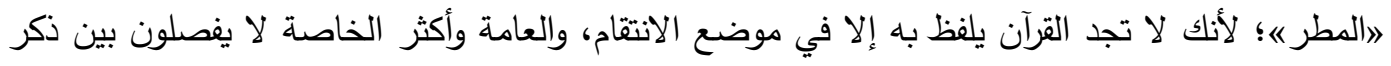

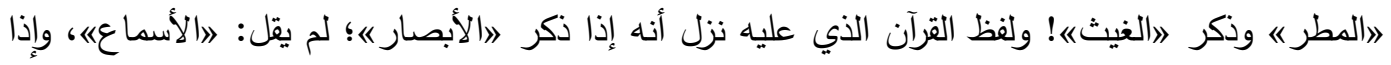

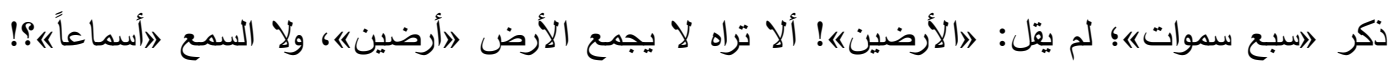

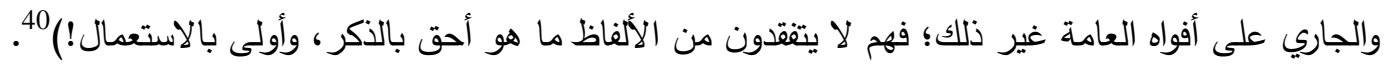

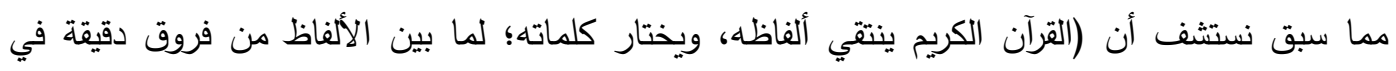
دلالاتها؛ فيستخدم كل لفظة بدقة؛ بحيث تؤدي معناها المراد في إحكام شديد، يكاد السامع يؤمن بأن هذا لخان

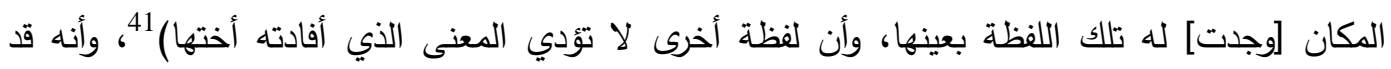

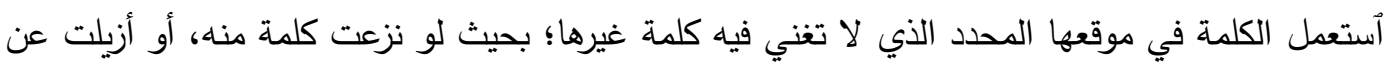

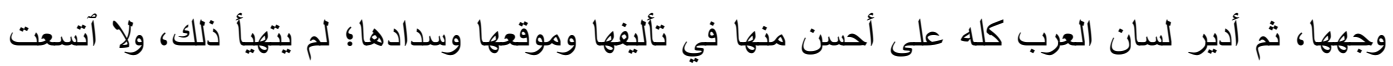
له اللغة بكلمة واحدة ويمكن كل أحد منا التوثق من ذلك بنفسه؛ وذلك أننا إذا حاولنا تغيير كلمة، أو تبديل لفظة من ألفاظ الكتاب

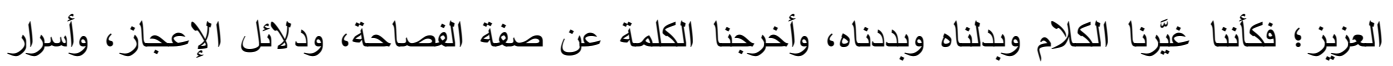

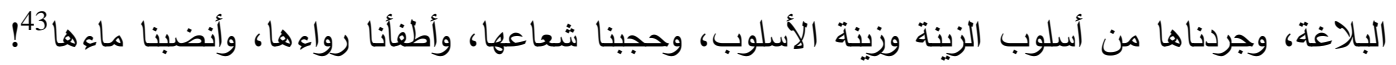
وما ذاك إلا لأن الكلمة في القرآن الكريم أشبه بالعضو في جنس الإنة الإنسان وهو يؤدي وظيفته بدقة وإحكام

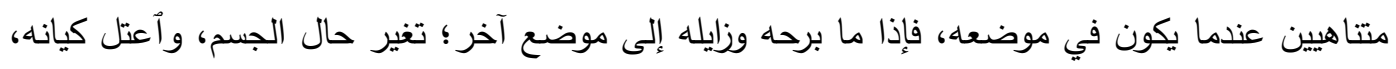

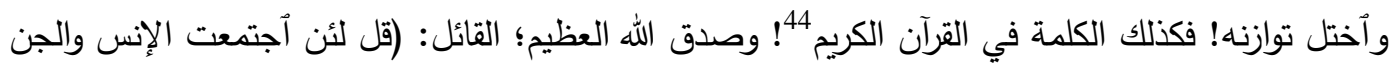
على أن يأتوا بمثل هذا القرآن لا يأتون بمثله ولو كان بعضهم لبعض ظهيراً) [الإسراء/ 88].

$$
\begin{aligned}
& 39 \text { ينظر : إعجاز القرآن والبلاغة النبوية/ص ص261، وجرس الألفاظ/ ص203. }
\end{aligned}
$$

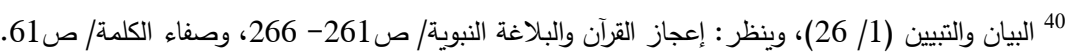

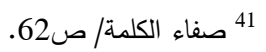

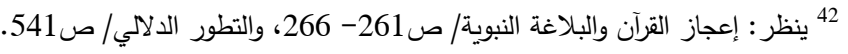

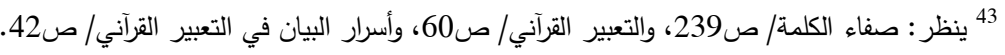

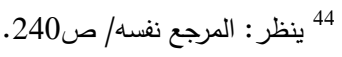

\section{IJHER}

International Journal of Humanities and Educational Research

Volume 2, Issue 4, December 2020, p.61-93 
فالقرآن الكريخ: (تعبير بياني مقصود؛ أي أن كل كلمة وكل حرف فيه وضع وضعاً مقصوداً) 45؛ إذ كان حقاً

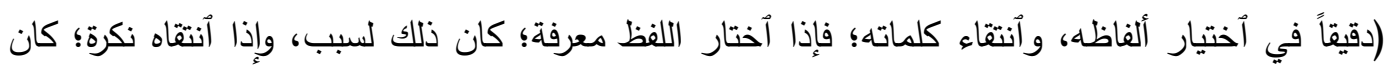
ذلك لغرض! كذلك إذا كان اللفظ مفرداً؛ كان ذلك لمقتضى يطلبه، وإذا كان مجموعاً؛ كان لحال يناسبه؛ وقد يختار الكلمة ويهمل مرادفها الذي يشترك معها في الدلالة، وقد يفضل كلمة على أخرى والكلمتان

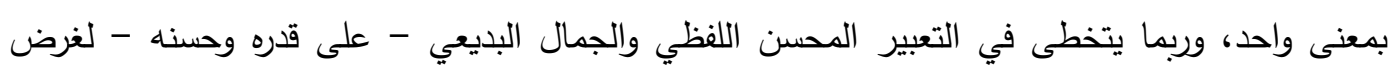
أسمى - وهو المحسن المعنوي - وكل ذلك لغرض يرمي إليه! وهكذا دائهاً: لكل مقام مقال في التعبير القرآني)

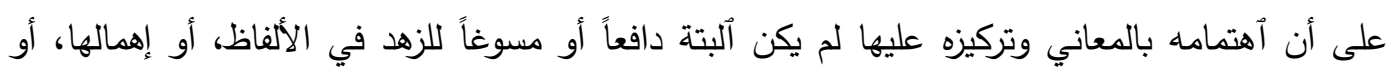

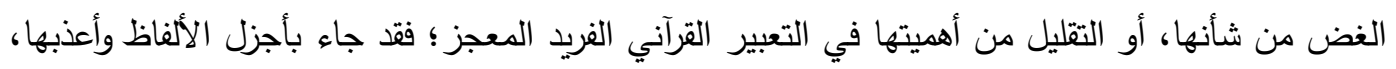

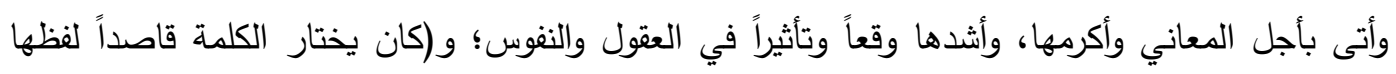

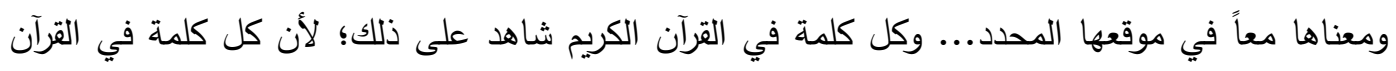

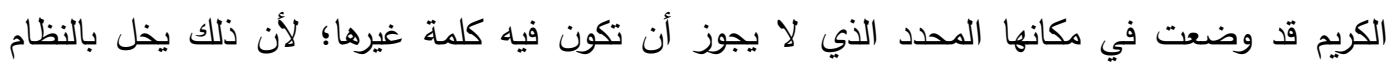

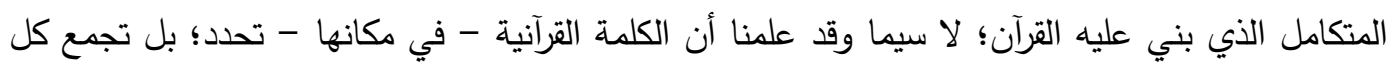

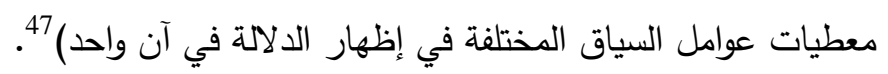

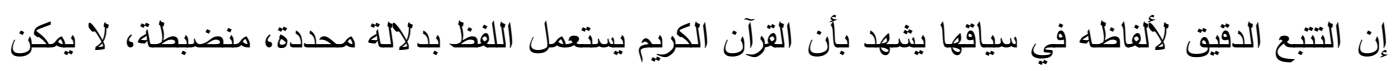

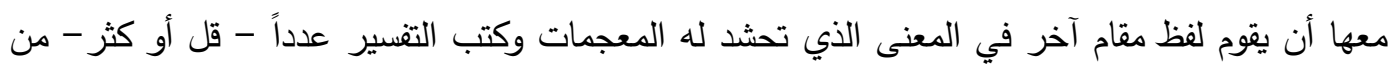

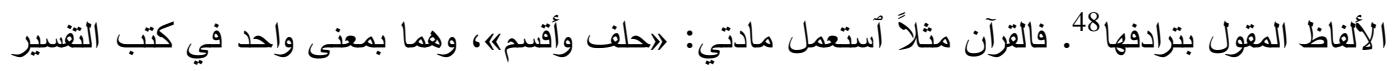

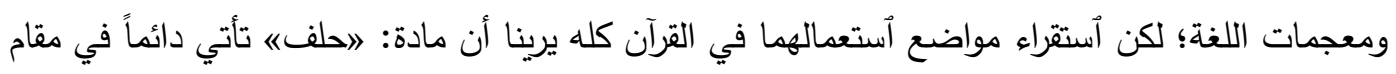

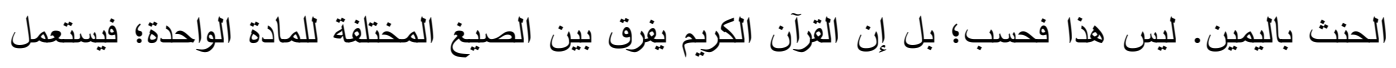

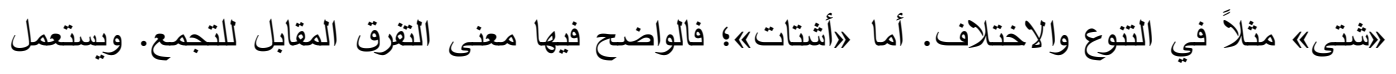

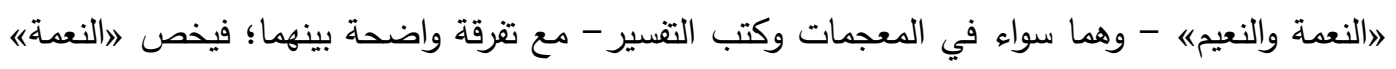

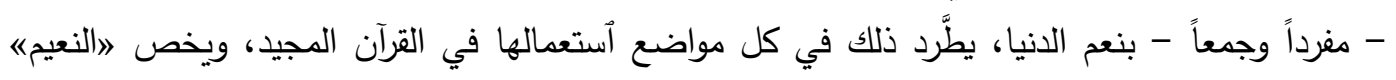

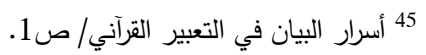

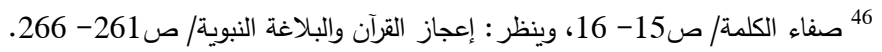

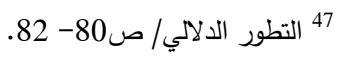

48 جرت عادة بعض أرباب المعاجم وكثير من أهل اللغة والتفسير من بيان معاني الألفاظ ودلالاتها بما يرادفها أو يقاربها في المعنى، وتفسير

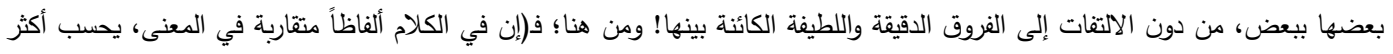

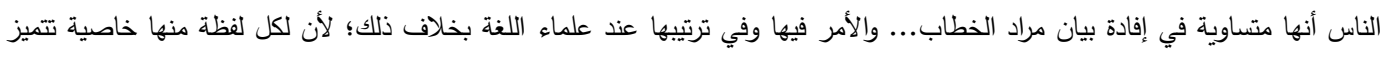

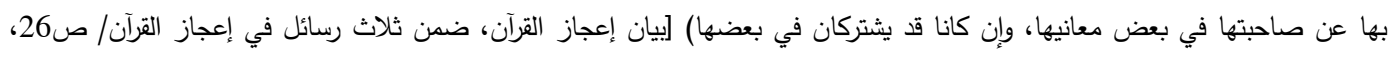

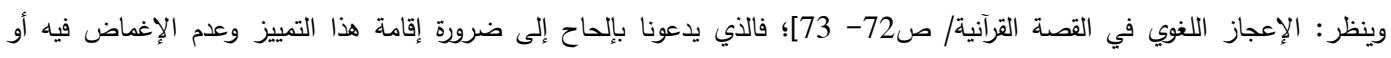

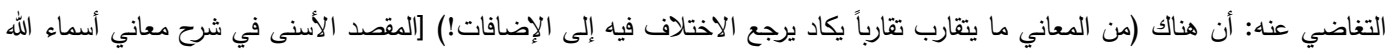

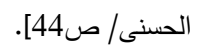

\section{IJHER}

International Journal of Humanities and Educational Research

Volume 2, Issue 4, December 2020, p.61-93 
بنعيم الآخرة، يطَّرد ذلك أيضاً في كل مواضع أستعمالها. وبعد كل هذا ليس لقائل أن يقضي على العربية بفقدان الحس اللغوي للألفاظ، والعجز عن ضبط الدلالات، وهذا كتابها الأكبر الموثق يبهرنا بدقة دلالة

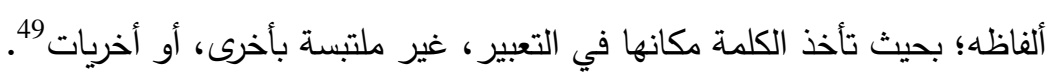

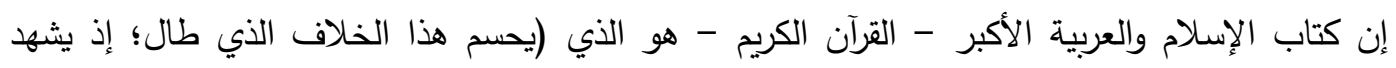

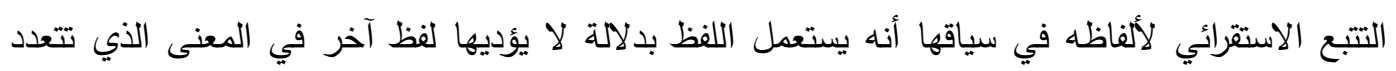

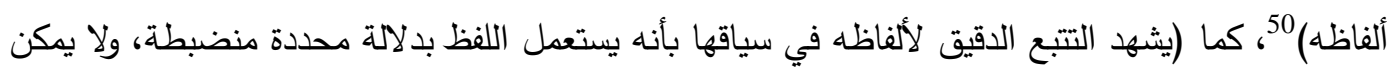

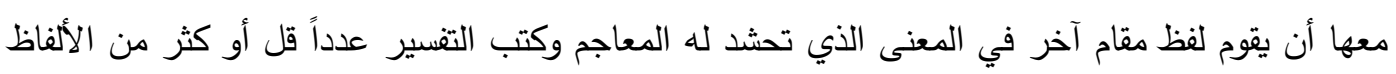

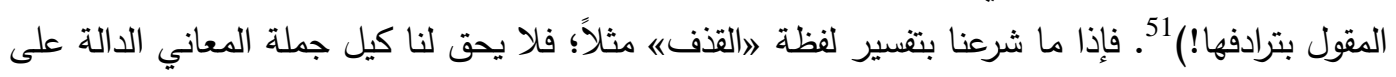

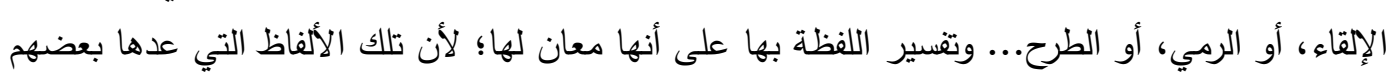
قيماً تفسيرية لـالتذفه لا تتطبق أنطباقاً تاماً على موحيات تلك اللفظة وقيمها التعبيرية وظلالها

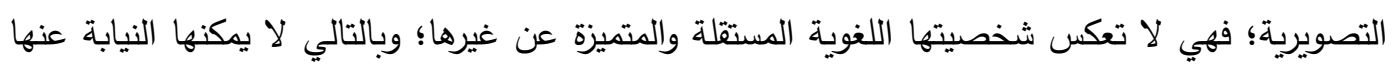

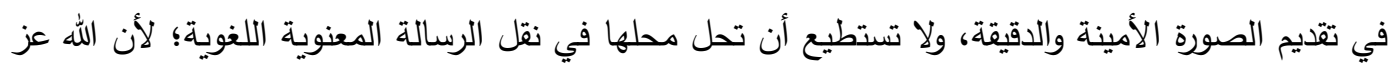

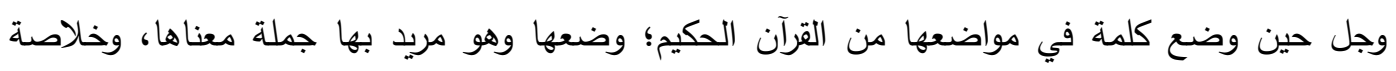

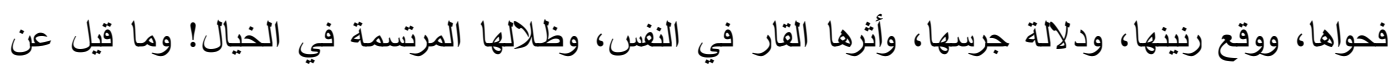

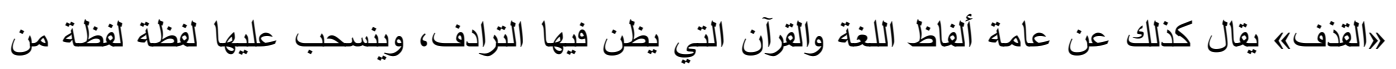

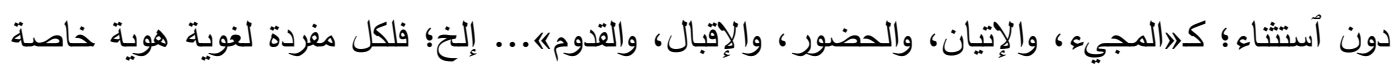

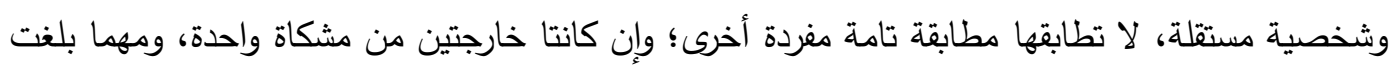

$$
\text { الوشيجة اللغوية والآصرة المعنوية بينهما في القرب حداً! }
$$

بهذا المقياس المحكم والمنضبط؛ يمكننا عد كل لفظة في القرآن الكريم شخصية لغوية مستقلة عن الأخرى

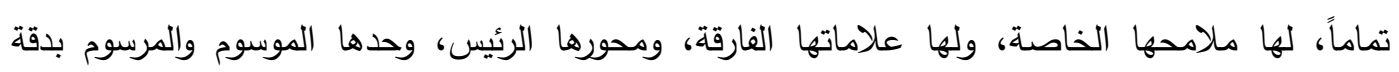
متتاهية؛ بحيث يمكن أن تتداخل وتشترك معها لفظة أخرى في بعض دلاهلاهلاتها الهامشية ومعانيها الثانوية

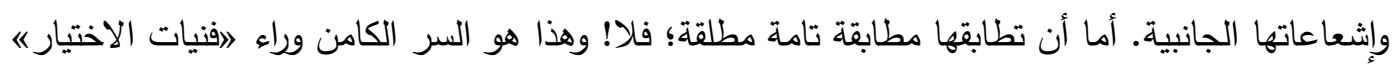
وما يلحقها من "جماليات العدوله في القرآن الكريم. صفوة القول فيما تقدم أن لا تطابق تاماً للفظ مع لفظ طراً في اللغة؛ حتى لا مزية لأحدهما على الآخر !وأن

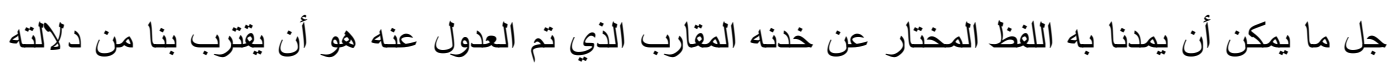

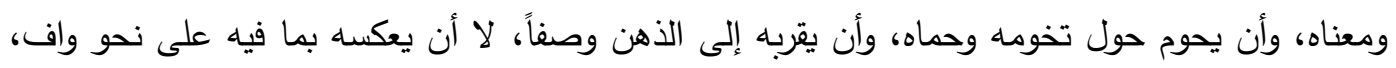
ولا أن يذوب أحدهما في الآخر ذوباناً تاماً؛ حتى يمكن أن يقال بأن أحدهما من حيث وديث المعنى كالآخر

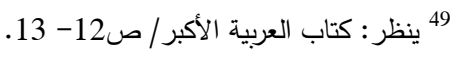

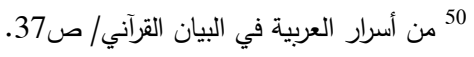

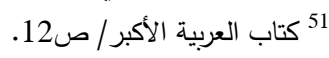

\section{IJHER}

International Journal of Humanities and Educational Research

Volume 2, Issue 4, December 2020, p.61-93 
تماماً، وحتى يمكن أن يفسر أحدها بالآخر من دون إضافة ملامح تمييزية أو علامات فارقة زائدة أو ناقصة لأحدهما عن الآخر ! فلكل لفظة شخصية لغوية تمتاز عن الأخرى بدلالاتها وموحياتها وظلالها

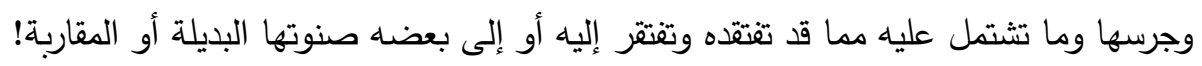

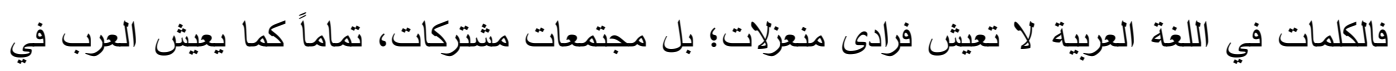

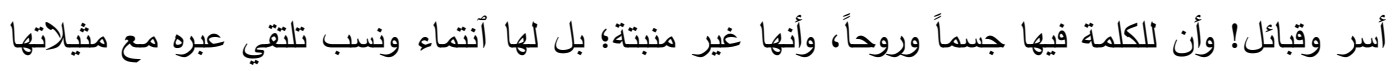

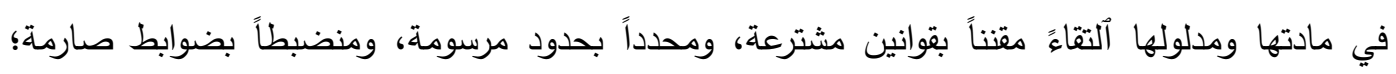

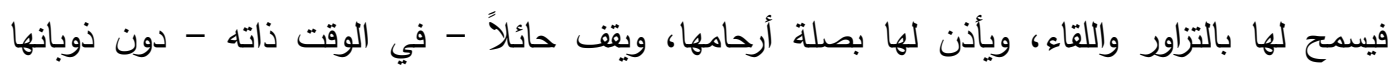

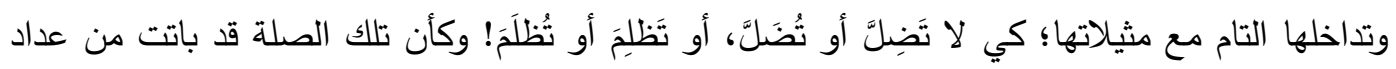
عوامل البسط في رزق تلك اللغة الثرية، ومن أسباب الإنساء في أثرها

\section{المبحث الثاني: نماذج تطبيقية لظاهرة (الاختيار والعدول) في القرآن الكريم}

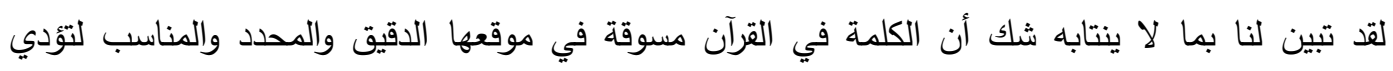

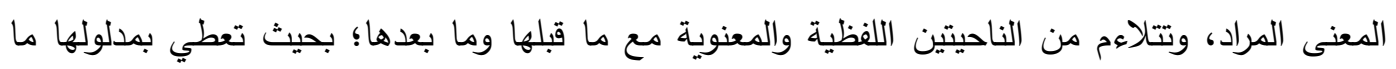

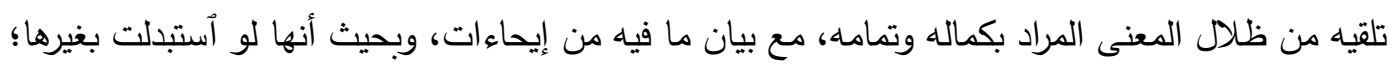

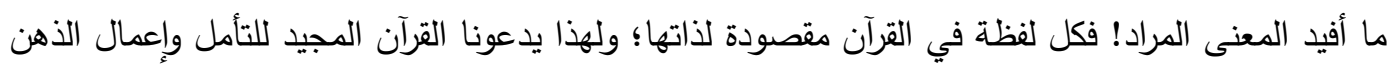
في التقريق بين اللفظة وشبيهاتها ضمن سياقاتها المتتوعة؛ فالحقيقة اللغوية قاضية بأن للكلمات القرآنية

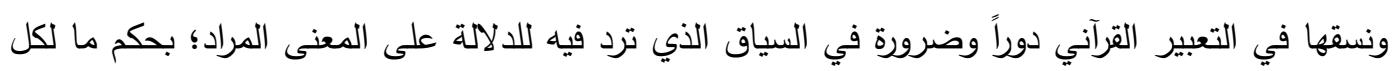

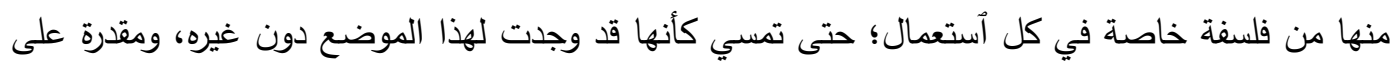

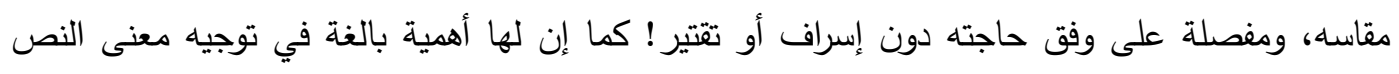

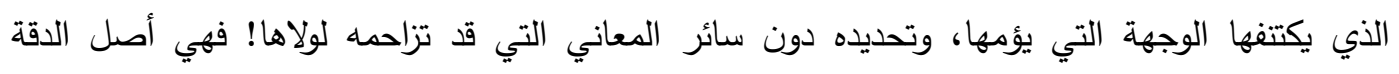

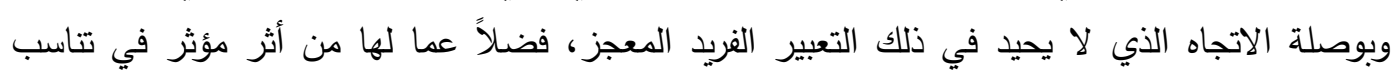
الإيقاع! وجميع كلمات القرآن قد رتبها عز وجل بتناسق وتدرج وإعجاز لغوي محسوب بدقة وإحكام متتاهيين!

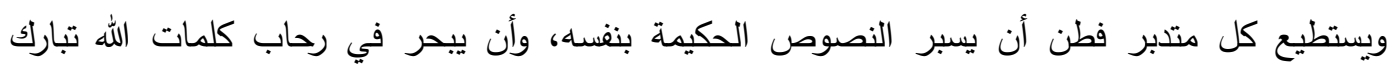

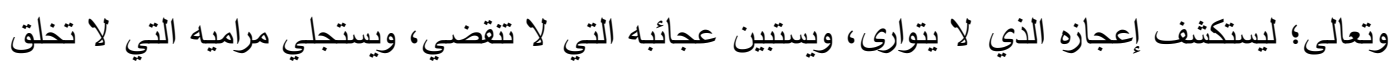

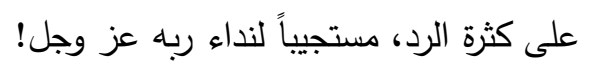
على أن ما نجده في رحاب كلام الله تعالى من إعجاز لغوي محسوب بدقة وإحكام متتاهيين في أستعمال

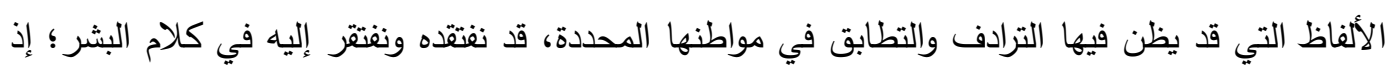
أشتمل كلام العرب - شعره ونثره - قبل الإسلام وبعده بين طياته على كثير من المصطلحات والألفاظ التي فواني

52 يظظر : اللغة العربية ومكانتها بين اللغات/ ص6- 7.

\section{IJHER}

International Journal of Humanities and Educational Research

Volume 2, Issue 4, December 2020, p.61-93 
يمكنتا تصنيفها في عداد الترادف، والتي لو ذهبنا نستقصيها؛ لطال بنا العد، وأعيانا الإحصاء، وضاق بنا المقام! وقد حاول أبو عودة في كتابه: 》التطور الدلاليه تتبع كثير منها وآستقصاءه، وإجراء موازنات

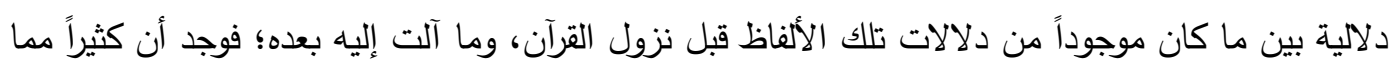

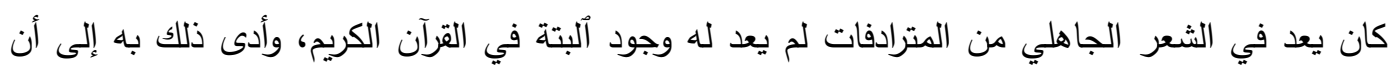

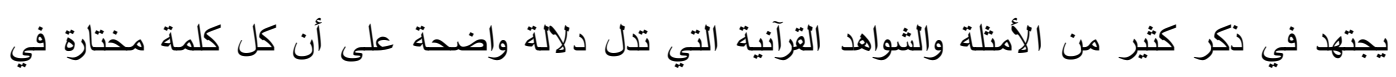
القرآن تحمل معنى غير الذي تحمله الكلمات الأخرى المعدول عنها التي يظن أنها مرادفة لها لهاتئ.

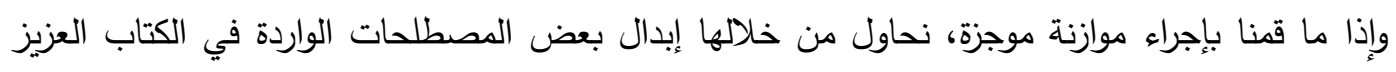

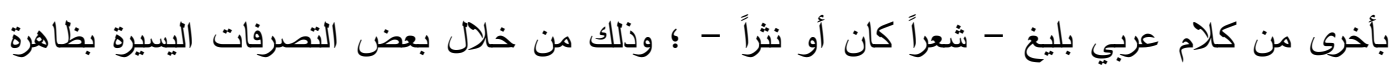

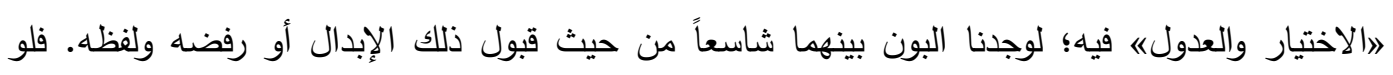

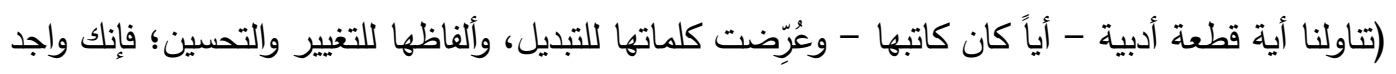

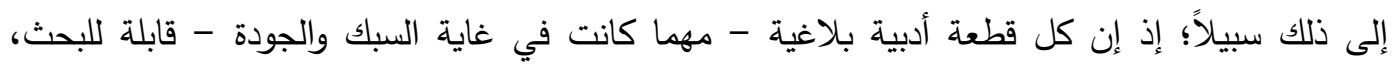

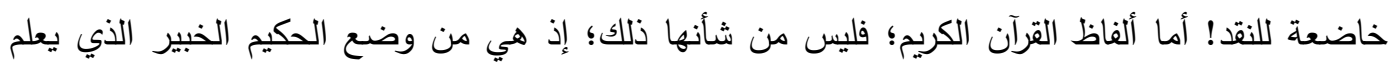

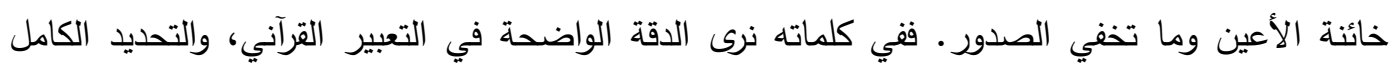

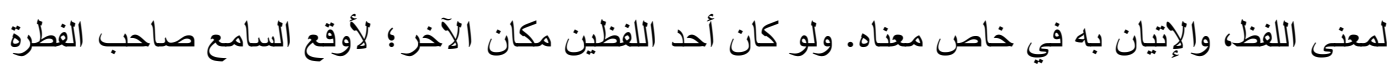
السليمة، والطبع الصحيح والذوق اللغوي، في حيرة واُرتباك، وأدخل عليه اللبس والخلط!)

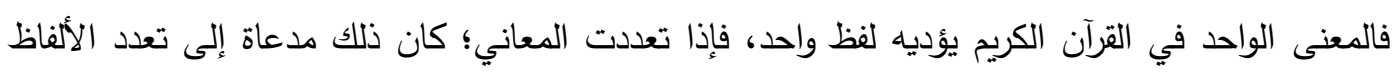

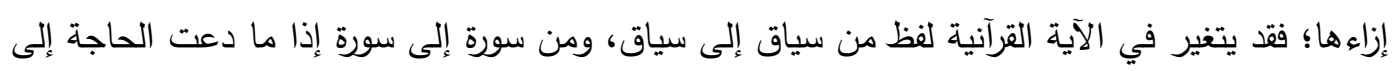
ذلك التغير. وفيما يأتي عرض لطائفة من ألفاظ القرآن الكريم التي تم اختيارها والعدول بها عن غيرها في سياقاته

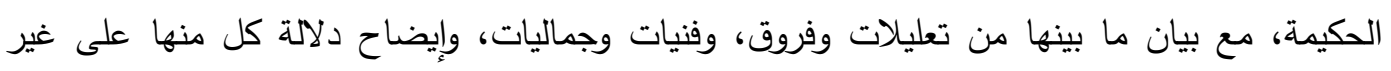
المعنى الذي دلت عليه أختها:

\section{الانفجار والانبجاس}

وردت قصة موسى عليه السلام في سور متعددة من القرآن الكريم، وبينها في سورتي البقرة والأعراف 55

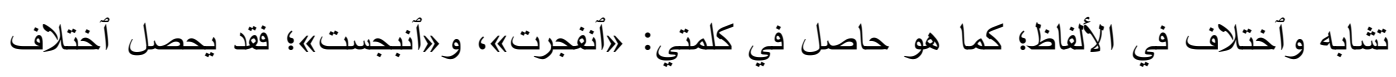

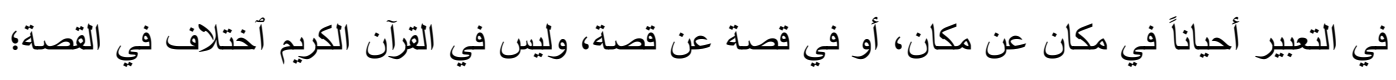

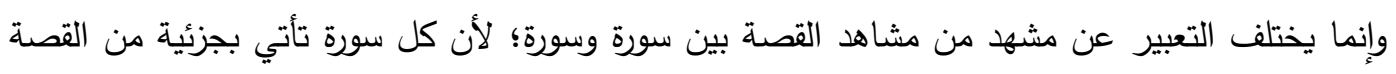

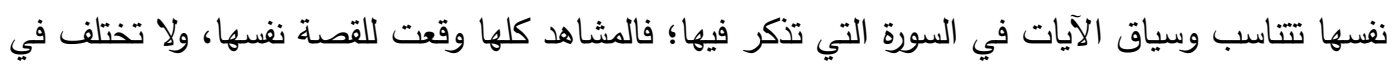

$$
\begin{aligned}
& 53 \text { ينظر : التطور الدلالي/ص8 ص- } 59 .
\end{aligned}
$$

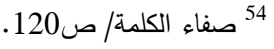

$$
\begin{aligned}
& 55 \text { تنظر : الآية } 60 \text { من [سورة البقرة]، والآية } 160 \text { من [سورة الأعراف]. }
\end{aligned}
$$

\section{IJHER}

International Journal of Humanities and Educational Research

Volume 2, Issue 4, December 2020, p.61-93 
الفحوى والحقيقة! فما الذي حدث فعلاً!! هل 》اُنفجرته الاثتتا عشرة عيناً، أم أنها 》أنبجست«؟! الجواب الذي لا يقبل الثك أو التأويل أن كليهما قد حصل، وبحسب ما يقوله المفسرون؛ فإن الحجر أنفجر أولاً بالماء الكثير ، ثم قل الماء بمعاصيهم! وفضلاً عما تقدم؛ فقد سيقت الآيات في [سورة البقرة] في معرض تكريم بني إسرائيل، وتعداد الآلاء والنعم الظاهرة والباطنة التي أسبغت عليهم؛ فذكرت فيها أمور كثيرة في مقام التفضيل والتكريم؛ لذا جيء بالكلمة التي تدل على الكثير: „اُنفجرته. أما في [سورة الأعراف]؛ فالسياق فيها في معرض الذّم والذكر لذنوبهم

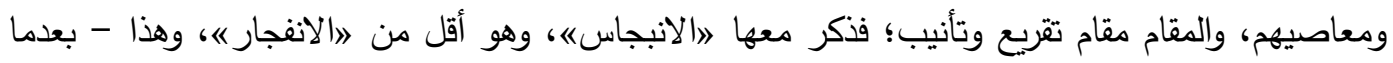

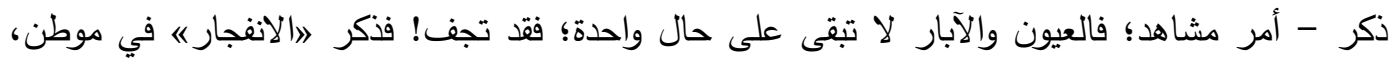

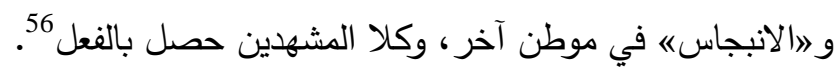
إن مرد الاختلاف في هذين اللفظين هو أن البلاغة والبيان أقتضيا أن يؤتى باللفظ الأول: „اُنفجرته ليدل

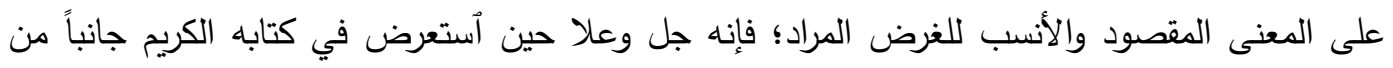

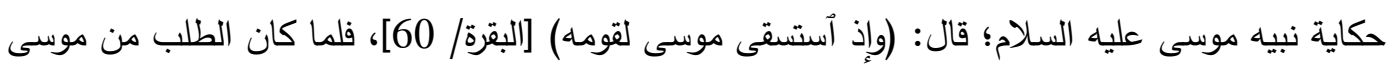

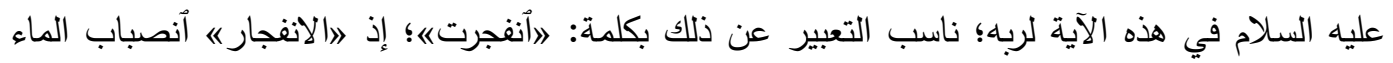

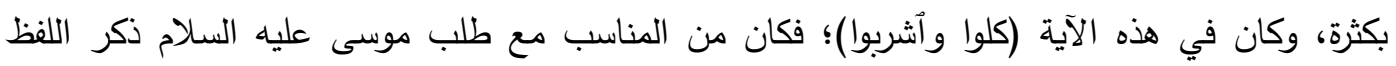

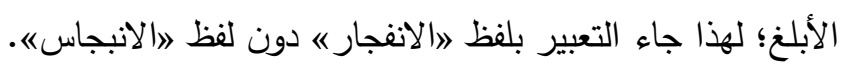

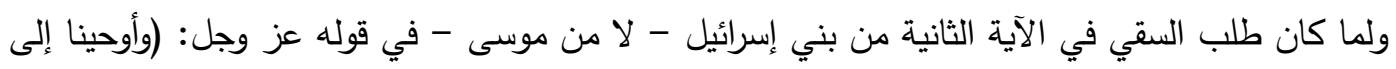

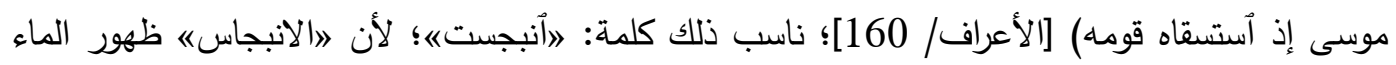

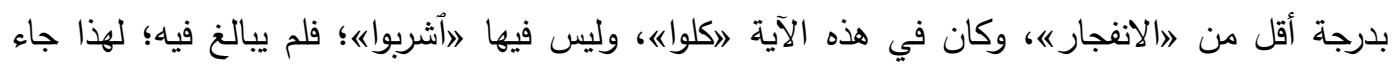

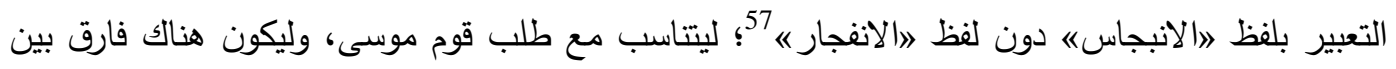
طلب موسى وطلب قومه 58. وهكذا فإن 》الانفجار " جاء مع ذكر الأكل والثرب: (كلوا وأشربوا)، وذلك حتماً سيكون بحاجة إلى قدر

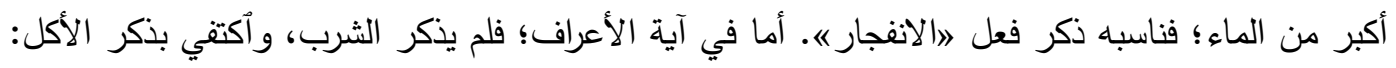
(كلوا من طيبات ما رزقناكم) [الأعراف/ 160]؛ فجيء باللفظ الدال على الماء الأقل بقدر الحاجة! والله وله

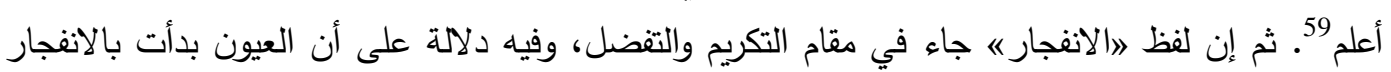

56 ينظر : البرهان في علوم القرآن (1/ 90)، ومعترك الأقران في إعجاز القرآن (1/ 87- 88)، والتعبير القرآني/ص286، وأسرار البيان في

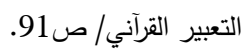

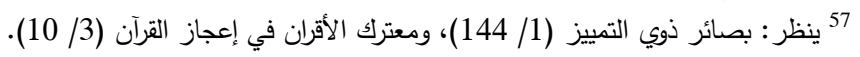

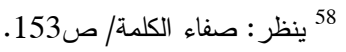

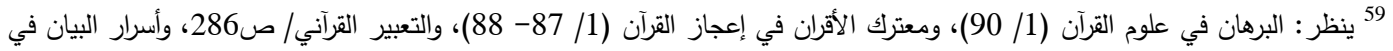

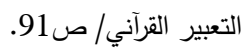

\section{IJHER}

International Journal of Humanities and Educational Research

Volume 2, Issue 4, December 2020, p.61-93 
بالماء الثديد؛ فجاء بحالة الكثرة مع التتعيم. أما لفظ 》الانبجاس«؛ فقد جاء في مقام التقريع، قل الماء

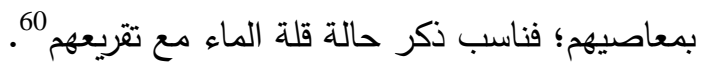

\section{(الحمد والثكر}

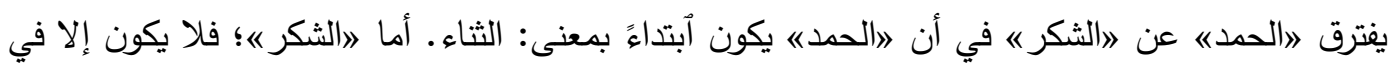

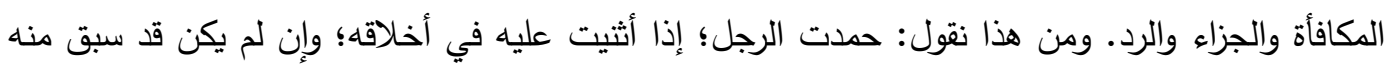

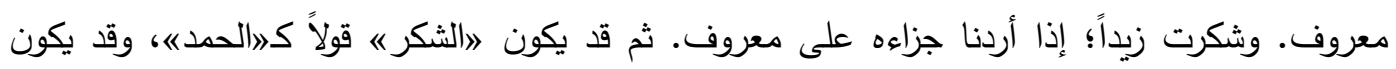

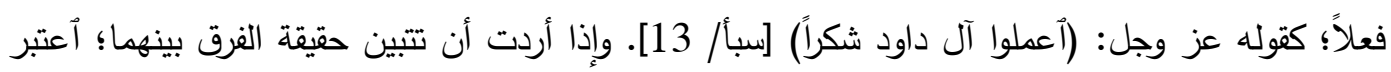

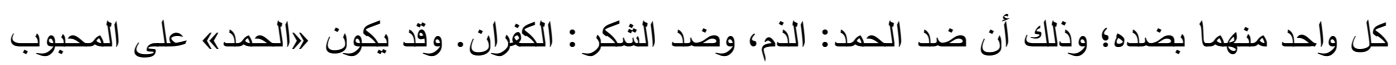

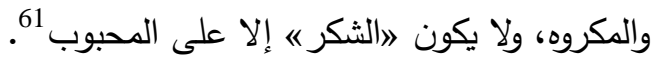

\section{الخشية والخوف}

ومن هذا الباب أيضاً: الفرق بين 》الخشيةه، و 》الخوفه؛ فقد يظن أنهما بمعنى واحد؛ لكن المتتعم

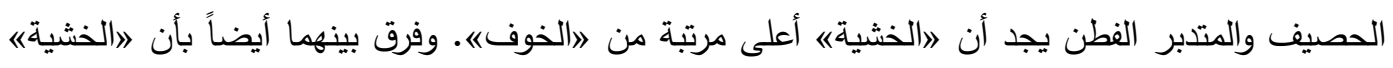

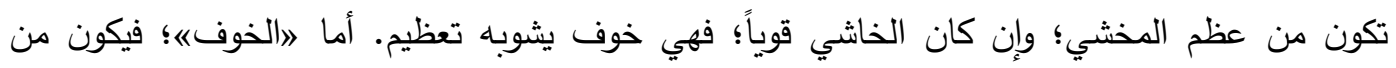

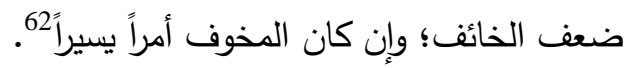

\section{الحلف والقصم}

«الحلفه في الأصل: (تأكيد الخبر بذكر المعظم)63، أو هو (إضافة الخبر إلى المعظم)64! أما الأصل في

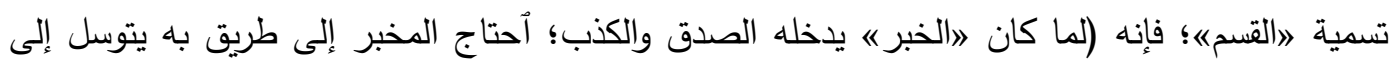

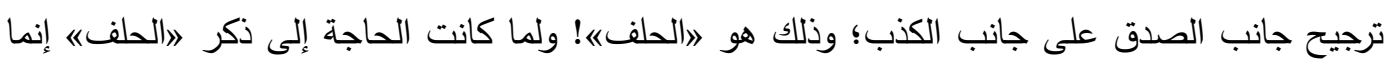

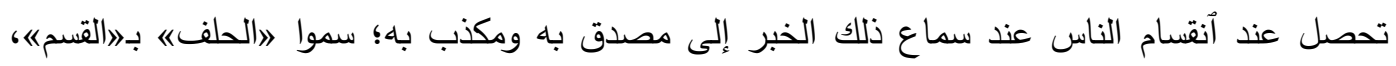

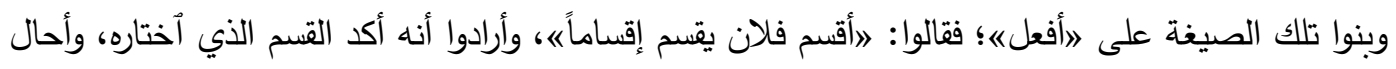

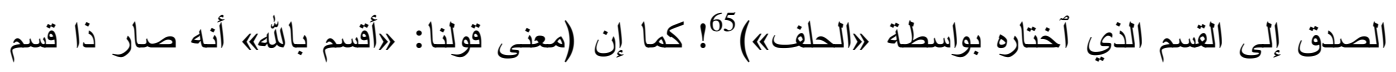
بالله، والقسم: النصيب، والمراد أن الذي أقسم عليه من المال وغيره قد أحرزه ودفع عنه الخصم بالله،

60

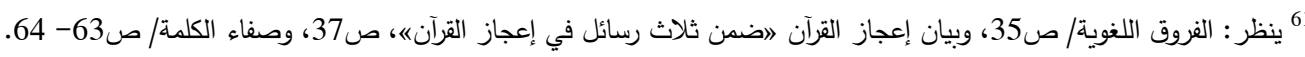

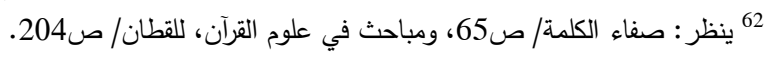

63 أحكام القرآن، للجصاص (321 (321) 64 المصدر نفسه (14/ 65 (321). 65 مفاتيح الغيب (113/ 117).

\section{IJHER}

International Journal of Humanities and Educational Research

Volume 2, Issue 4, December 2020, p.61-93 
والحلف من قولك: 》سيف حليف《؛ أي: قاطع، ماض، فإذا قلت: 》حلف باللهی؛ فكأنك قلت: 》قطع

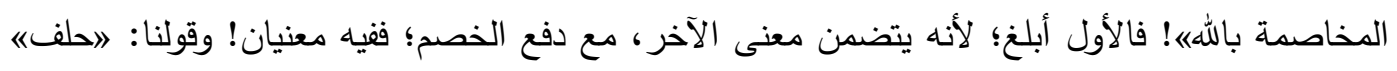

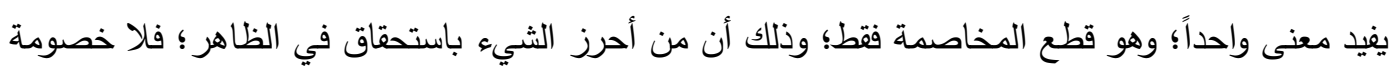
بينه وبين أحد فيه، وليس كل من دفع الخصومة في الثيء؛ فقد أحرزه)

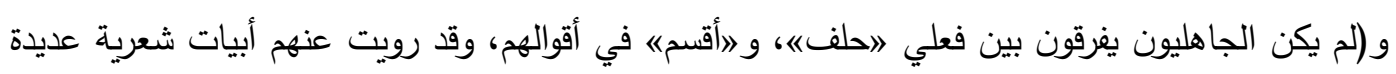

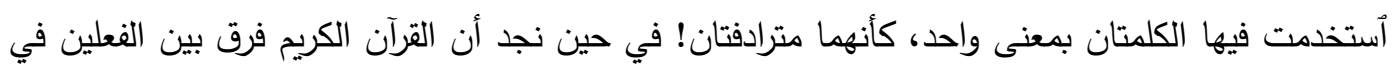

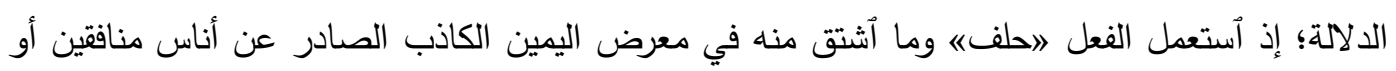

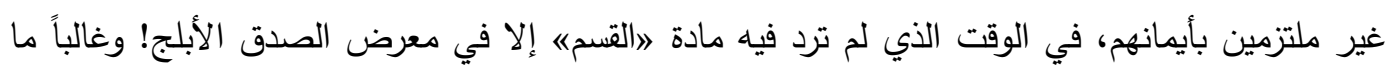

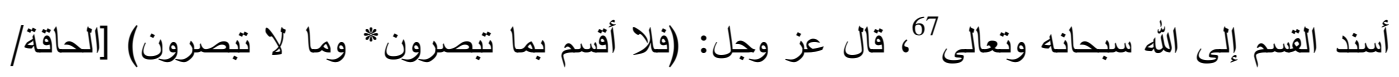

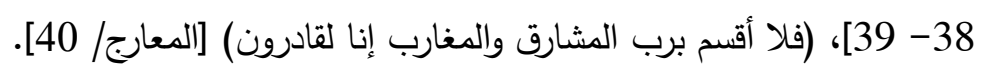

\section{الحلم والرؤيا}

ومن الألفاظ القرآنية التي يظن فيها أكثرهم أنها مترادفة: 》الحلم والرؤياه، ومعجمات اللغة تفسر إحداهما

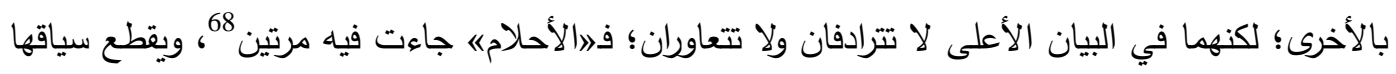

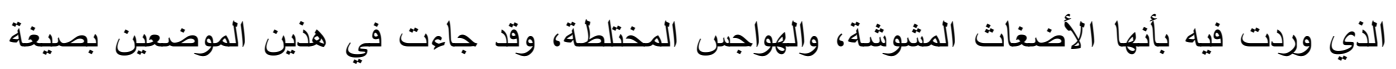

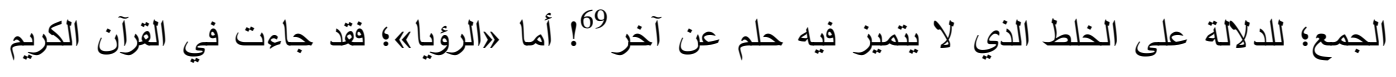

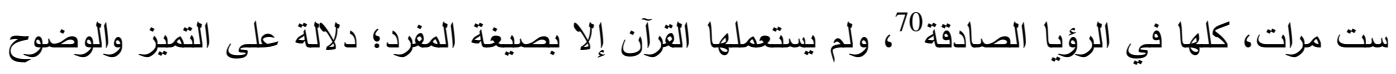
وصفاء المرئي

\section{الثتح والبخل}

ومن ذلك أيضاً: 》الشح والبخله؛ فالشح هو البخل الثديد مع الجشع والطهع؛ وهو أن يبخل الإنسان بما

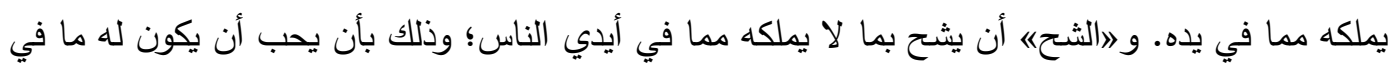
أيديهم بالحل والحرام؛ فلا يقنع بـ وقيل: إن الفرق بينهما هو أن البخل: نفس المنع، والثح: هو الحالة

$$
\begin{aligned}
& 66 \text { الفروق اللغوية (1/ 429). } \\
& 67 \text { التطور الدلالي/ لروف ص514. }
\end{aligned}
$$

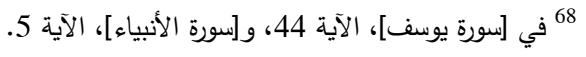

69

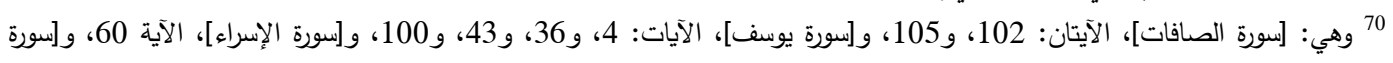

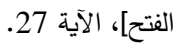

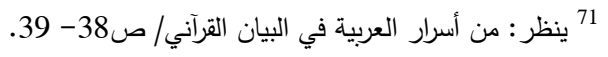
72 يظرر : اللباب في علوم الكتاب (15/ 207 2015).

\section{IJHER}

International Journal of Humanities and Educational Research

Volume 2, Issue 4, December 2020, p.61-93 


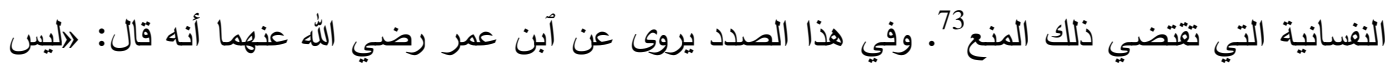

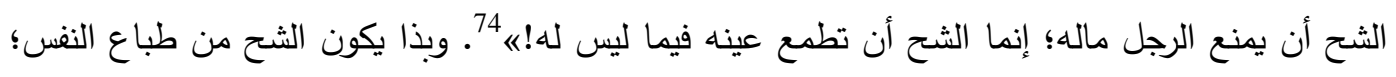
فإن النفوس شحيحة بالأثياء المحببة! ويجوز أن يكون المراد من الثح ما جبلت عليه النفوس من المشاحة

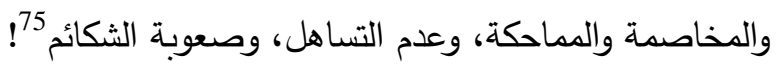

\section{الغضب والأسف}

جاء في تفسير الطبري: (قال أبو الدرداء رضي الله عنه: قول الله عز وجل: (فرجع موسى إلى قومه

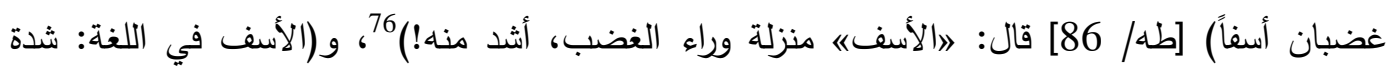
الغضب) المتلهف على الثيء! ثم كثر ذلك؛ حتى جاء في معنى الغضب وحده في قوله هئه: (فلما آسفونا أنتقهنا

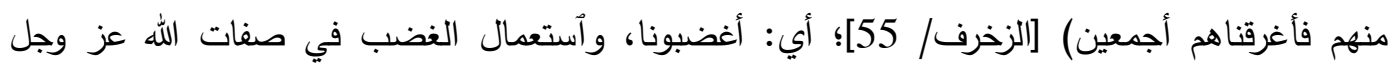

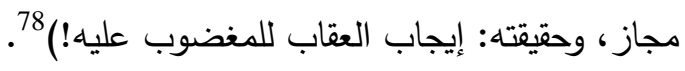

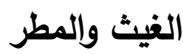

إن أستعمال العرب قبل الإسلام للفظي: 》الغيث والمطر يكاد يكون واحداً بلا فرق بينهما. أما القرآن الكريم؛ فقد جعل بينهما فرقاً واضحاً، وأعطى لكل منهما دلالة تميزه عن أخيه، وجعل كلاً منهما مصطلحاً

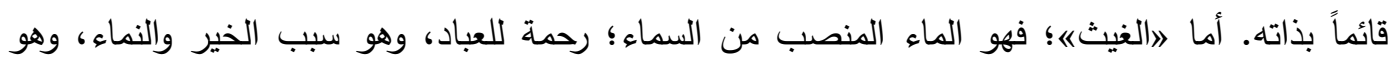

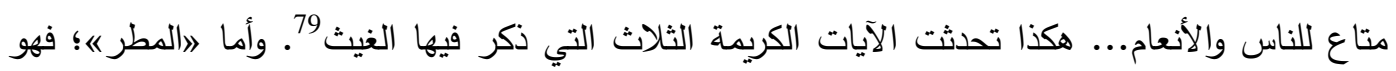

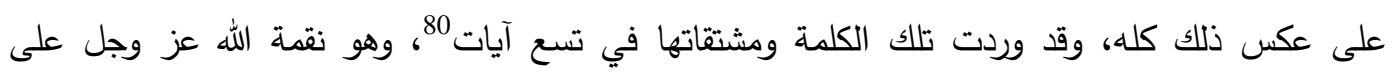

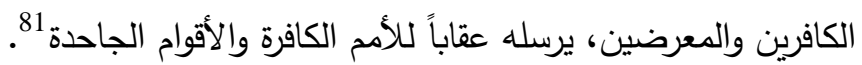

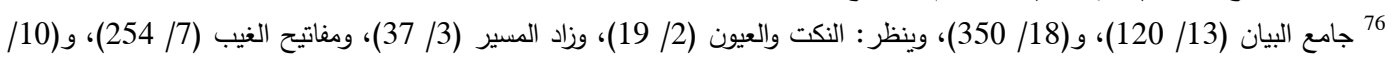

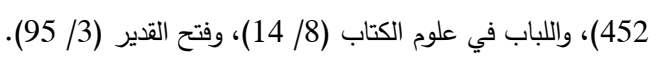

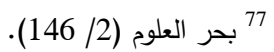
الفروق اللغوية/ ص128 128

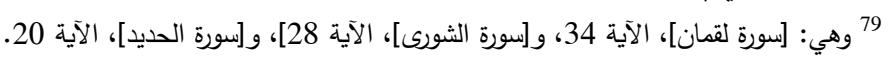

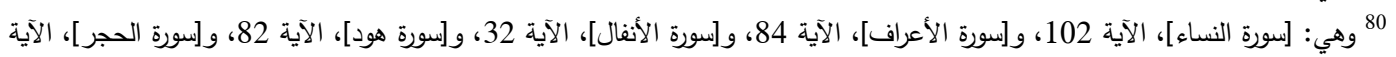

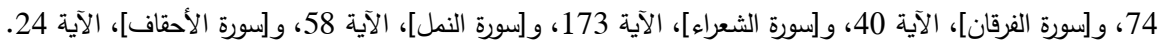

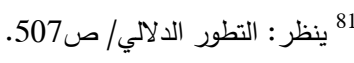

\section{IJHER}

International Journal of Humanities and Educational Research

Volume 2, Issue 4, December 2020, p.61-93 
(إن القرآن الكريم قد أحدث مصطلحات جديدة من خلال السياق القرآني؛ حيث أعطى بعض الكلمات

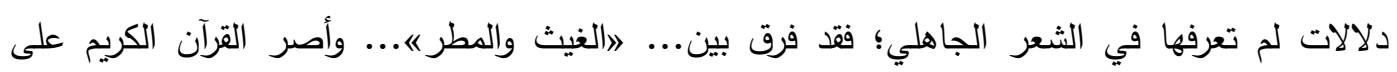
أستعمال 》المطر في حالات العذاب والعقاب في الدنيا، مثلما أصر على أستعمال 》الغيثه في في معاني الخير والنماء... وهذا أسلوب جديد لم يعرفه الشعر الجاهلي الذي لم يفرق بين دلالة هذه الكلمات التي يبدو

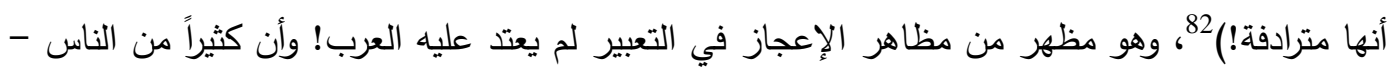

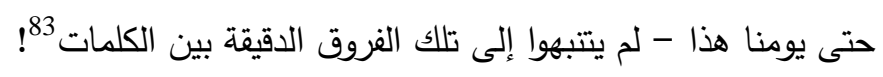

\section{الريح والرياح}

إن لفظي: 》الريح والرياحه تحملان الصورة نفسها والدلالة ذاتها في كلام العرب قبل الإسلام؛ فلم يفرقوا

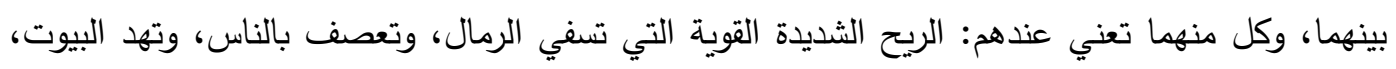

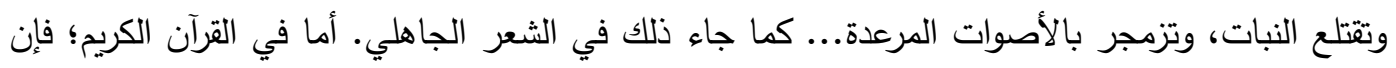

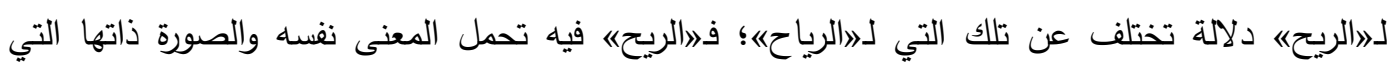
ذكرت في نصوص الشعر الجاهلي: الريح الثديدة العاصفة، قال جلت قدرته: (وأما عاد فأهلكوا بريح صرصر عاتية) [الحاقة/ 6]. أما 》الرياحه في القرآن الكريم؛ فهي على العكس من ذلك: الرياح الهادئة

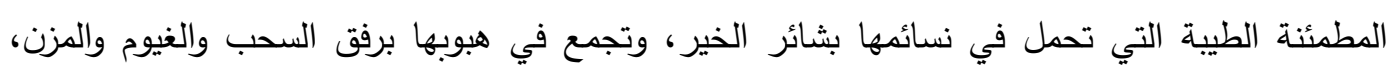

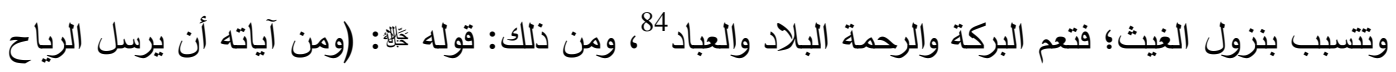

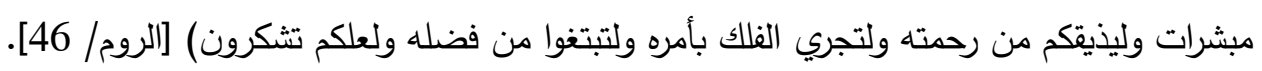

$$
\text { الريب والثك }
$$

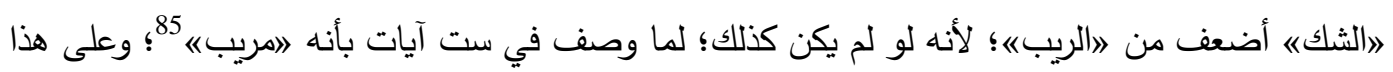

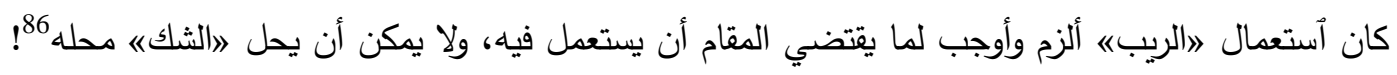

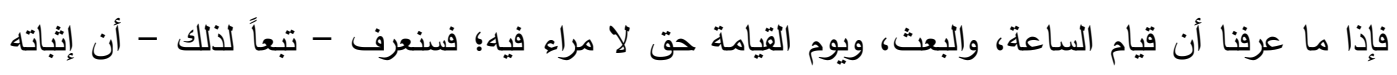

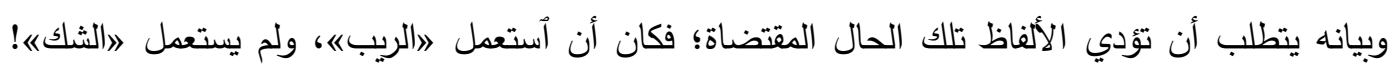

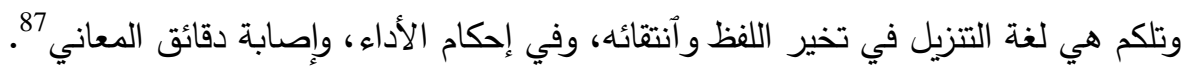

$$
\begin{aligned}
& 82 \\
& 83 \text { ينظر : البيان والتبيين (1/ 26)، والتطور الدلالي/ صل509.509، وصفاء الكلمة/ ص612. } \\
& 84
\end{aligned}
$$

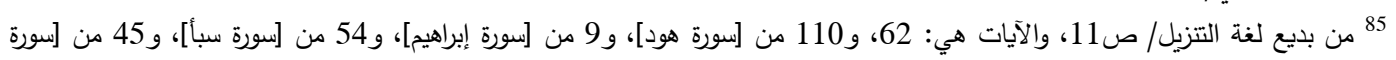

$$
\begin{aligned}
& \text { فصلت]، و14 من [سورة الثورى]. }
\end{aligned}
$$

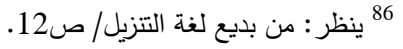

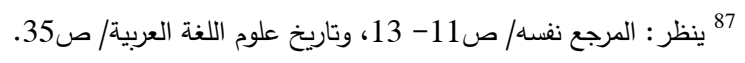

\section{IJHER}

International Journal of Humanities and Educational Research

Volume 2, Issue 4, December 2020, p.61-93 
الأل والصغار

قال أبو هلال: (الفرق بين 》الصغار والذله: أن الصغار هو: الاعتراف بالذل، والإقرار به، وإظهار صغر

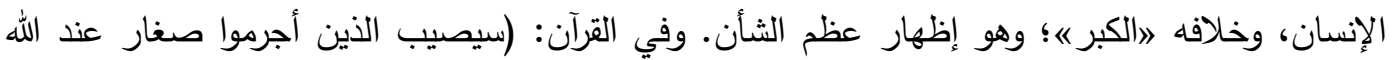
وعذاب شديد بما كانوا يمكرون) [الأنعام/ 124]؛ وذلك أن العصاة بالآخرة مقرون بالذل، معترفون بها

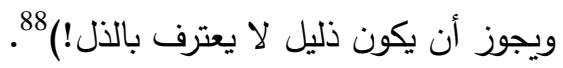

\section{القعود والجلوس}

و 》القعوده يستعمل في كل ما يكون فيه لبث ومكث! بخلاف 》الجلوس《؛ ولهذا يقال لكبار السن من

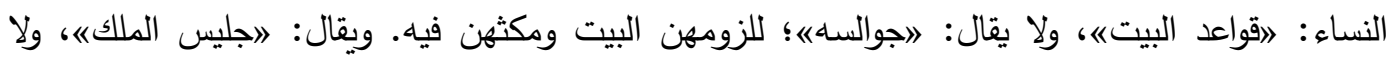
يقال: 》قعيده《؛ لأن مجالس الملوك يستحب فيها التخفيف؛ وعلى هذا جاء قوله جل وعلا: (إن المتقين في جنات ونهر * في مقعد صدق عند مليك مقتدر) [القر/ 54- 55]؛ فجاء التعبير القرآني (في مقعد

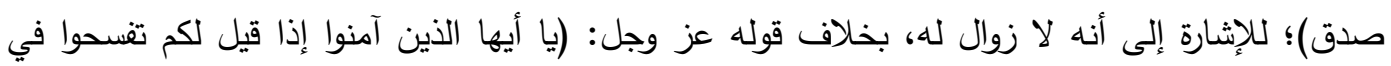

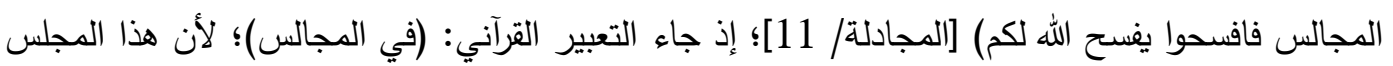
يجلس فيه زمان يسير 89.

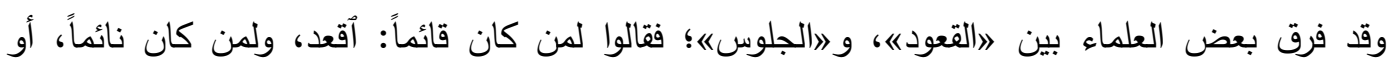

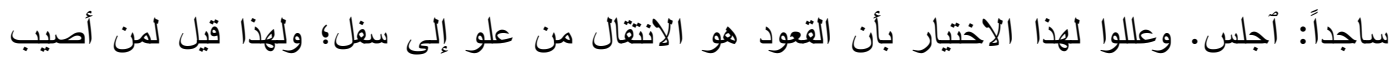

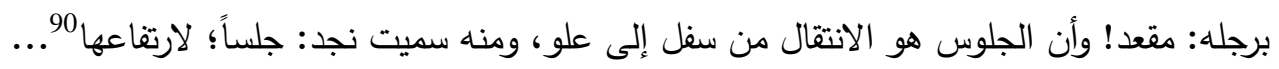

\section{المجيء والإتيان}

ومن ذلك: الفرق بين 》جاء《، و 》أتى《؛ فالفعل 》جاء《 يقال عادة في الجواهر والأعيان والأمور المحسوسة،

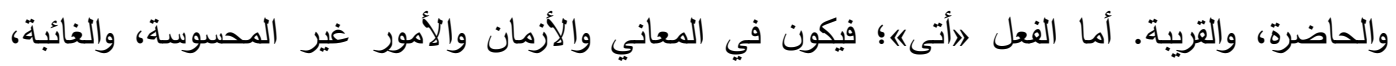
والبعيدة، قال سبحانه: (وجاء ربك والملك صفاً صفاً) [الفجر / 22]؛ أي: أمره؛ والمراد به: أهوال يوم القيامة المشاهدة. وقال تعالى: (ولكل أمة أجل فإذا جاء أجلهم لا يستأخرون ساعة ولا يستقدمون) [الأعراف/ 34]؛ لأن الأجل كالمشاهد؛ ولهذا عبر عنه بالحضور في قوله تعالى: (حتى إذا حضر أحدهم الموت قال إني

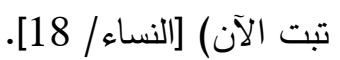

\footnotetext{
88 الفروق اللغوية (1/ 314).

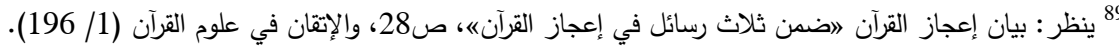

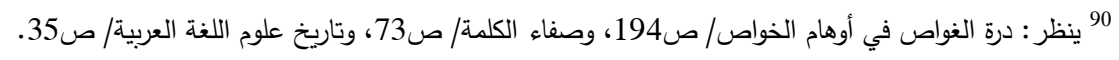


ومن ذلك أيضاً: قوله جلا وعلا: (وقال فرعون أُئتوني بكل ساحر عليم* فلما جاء السحرة قال لهم موسى

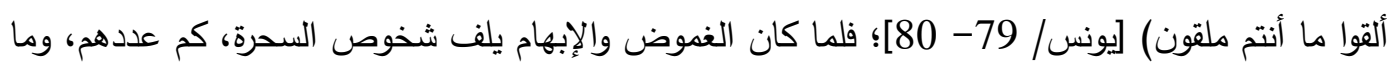
وصفهم، ومن سيأتي منهم ومن سيتخلف؛ جاء التعبير بهالإيتاء أو الإتيانه؛ أما وقد تبين ذلك كله جلياً

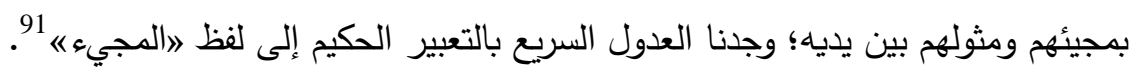

\section{البعث والإرسال}

و(الفرق بين 》البعث«، و االإرساله أنه يجوز أن يبعث الرجل إلى الآخر الحاجة يخصه دونك ودون

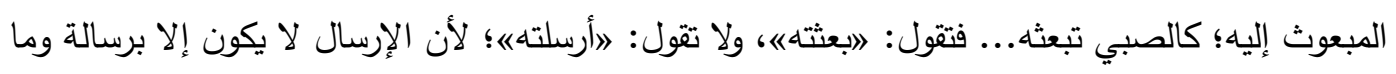
يجري مجراها).92.

\section{التلاوة والقراءة}

ففي الفعل 》تلان معنى أوسع مما في 》قرأه؛ إذ إن التلاوة هي تدبر آيات الله وفهمها والعمل بها. في حين

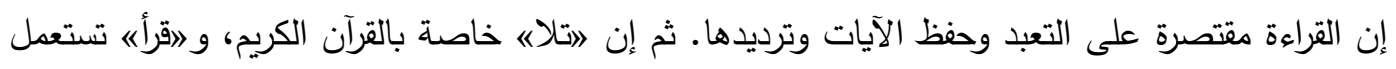
في القرآن وغيره ${ }^{93}$ جاء في لاقواعد التقسير هل للسبت: (إن التلاوة لا تكون في الكلمة الواحدة، والقراءة تكون فيها. تقول: قرأ فلان أسمه، ولا تقول: تلا أسمه؛ وذلك أن أصل التلاوة من قولك: تلاء الثيء الثيء الثيء يتلوه؛

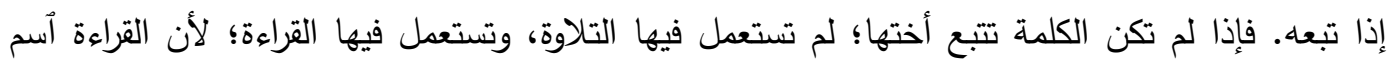
لجنس هذا الفعل)

\section{السغب والمخمصة والجوع}

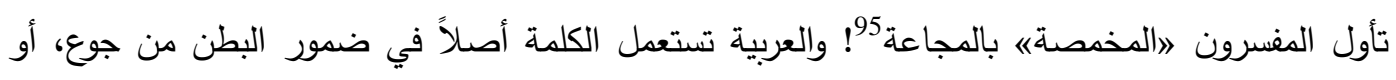

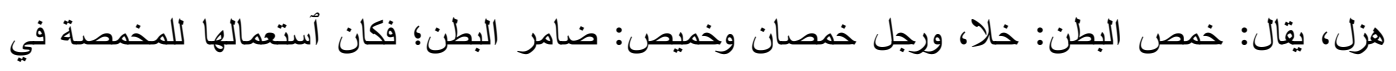

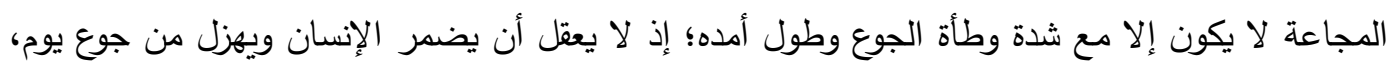

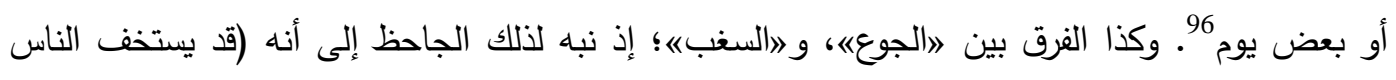

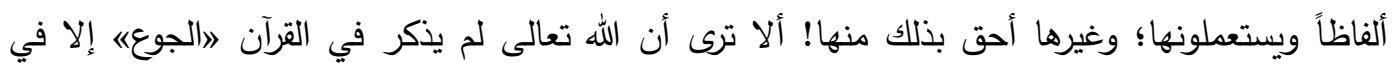

$$
\begin{aligned}
& \text { 291 ينظر : الكثاف (2/2 274). }
\end{aligned}
$$

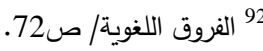

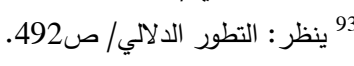

$$
\begin{aligned}
& \text {. } 466-465 / 1)^{94}
\end{aligned}
$$

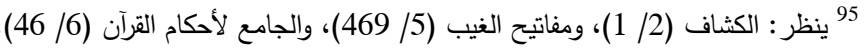

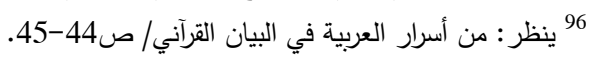

\section{IJHER}

International Journal of Humanities and Educational Research

Volume 2, Issue 4, December 2020, p.61-93 
موضع العقاب، أو في موضع الفقر المدقع والعجز الظاهر؟! والناس لا يذكرون 》السغبه، ويذكرون

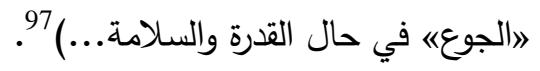

\section{الزوج والمرأة وإلصاحبة}

يستعمل البيان القرآني كلمة: 》زوجه حيثما تحدث عن آدم وزوجه؛ في حين أستعمل كلمة: 》آمرأةه في

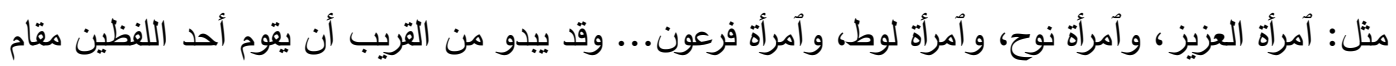

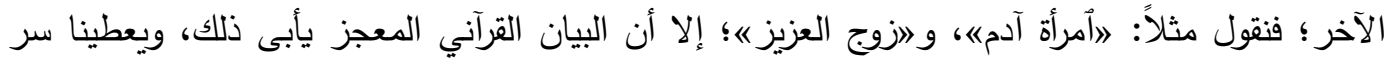

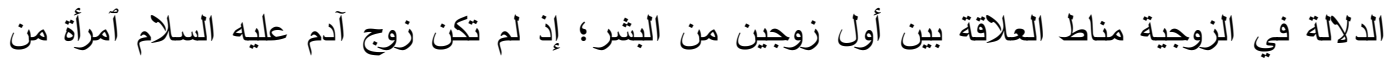

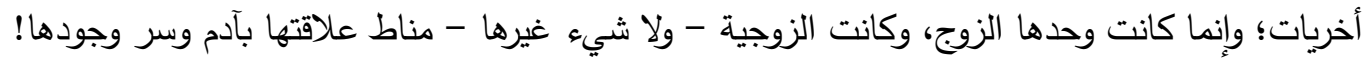

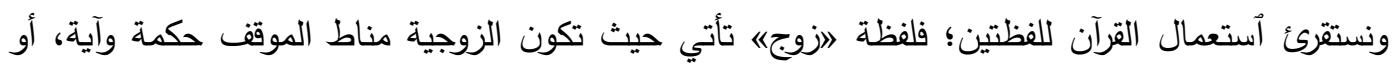

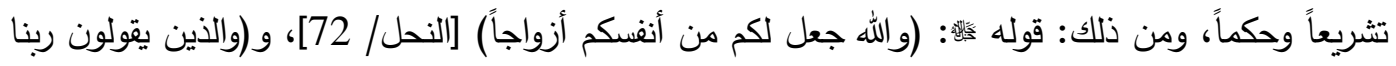

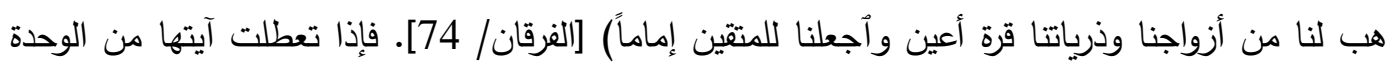

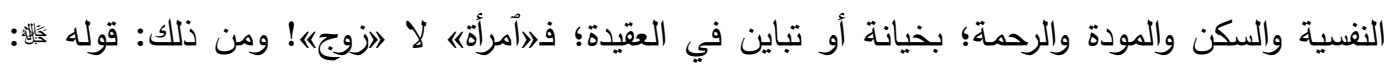

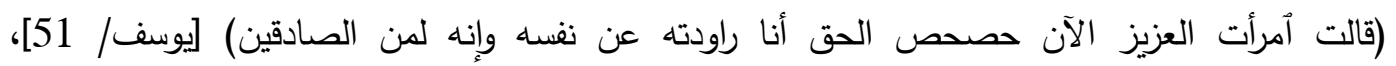
و (ضرب الله مثلاً للذين كفروا أمرأت نوح وأمرأت لوط كانتا تحت عبدين من عبادنا صالحين فخانتاهما...

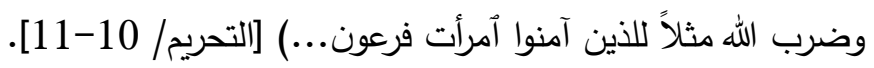
ثم إن حكمة الزوجية في الإنسان وسائر الكائنات الحية من حيوان ونبات، هي آتصال الحياة بالتوالد، وفي

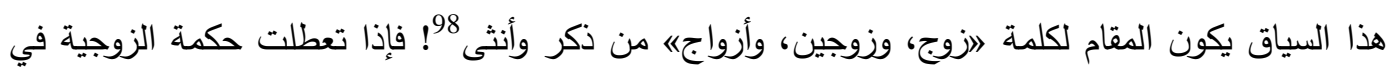

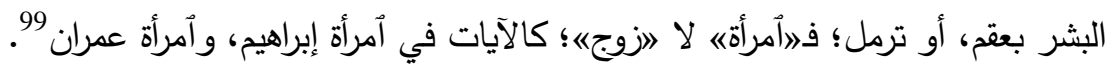

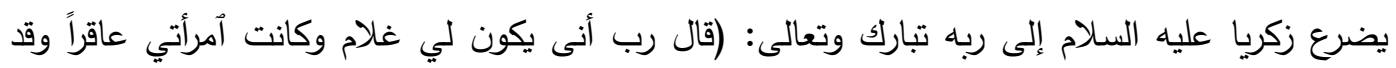

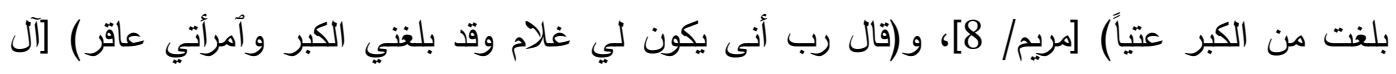

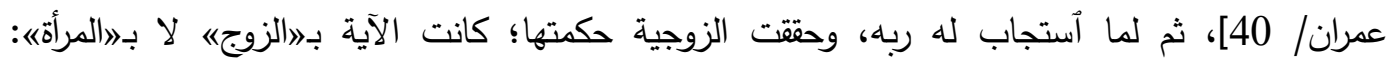

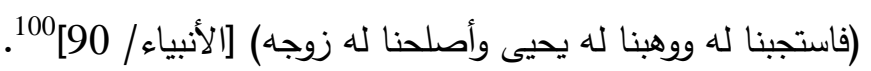

98 تنظر : الآيات: [سورة النساء]، الآية 1، و[سورة الأنعام]، الآية 139، و[ستورة هود]، الآية 40، و[سورة الرعد]، الآية 3، و[سورة طه]، الآية

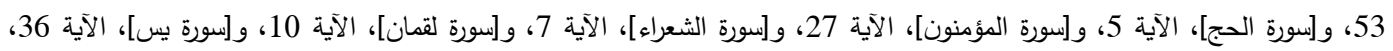

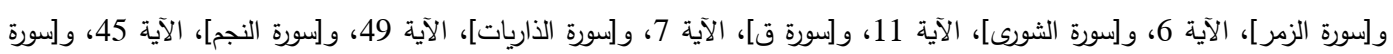

النبأ]، الآية 8.

99 [سورة آل عمران]، الآية 35، و[سورة هود]، الآية 71، ولسورة الذاريات]، الآية 29.

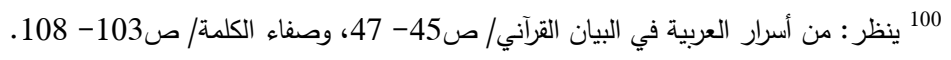

\section{IJHER}

International Journal of Humanities and Educational Research

Volume 2, Issue 4, December 2020, p.61-93 
أما 》الصاحبةه؛ فهي التي تعاشر المرء ولو لساعة واحدة في العمر ؛ ولو كانت العلاقة الرابطة بينهما عابرة أو غير مشروعة! وقياساً بقصر مدتها؛ فقد نفاها الباري عز وجل عن نفسه من باب نفي نفي الأولى، وتنزه عن

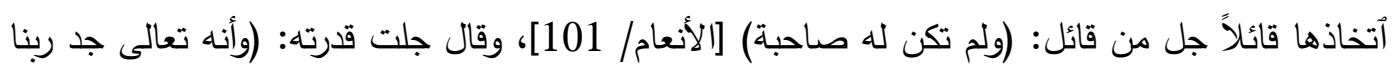

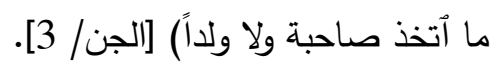

\section{الوفاة والموت}

وقوله سبحانه: (الله يتوفى الأنفس حين موتها والتي لم تمت في منامها فيمسك التي قضى عليها الموت التهاه

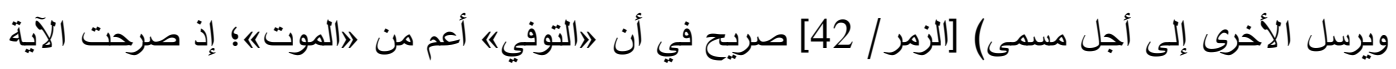

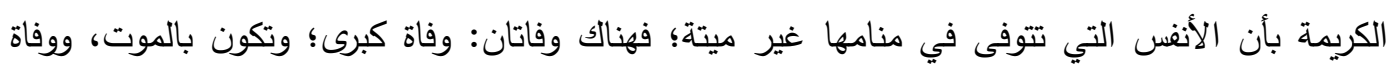
صغرى؛ وتكون بالنوم 101!

\section{الاختلاف والتفاوت}

》التقاوته في القرآن كله مذموم؛ ولهذا نفاه الله عز وجل عن فعله فقال: (الذي خلق سبع سموات طباقاً ما

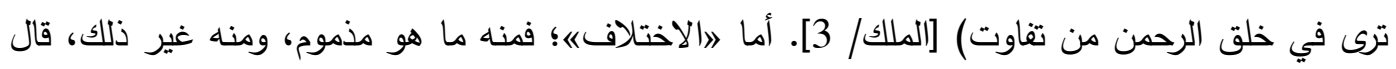
تبارك وتعالى: (وله أختلاف الليل والنهار) [المؤمنون/ 80]؛ فهذا الضرب من من الاختلاف يكون على سنن واحد، وهو دال على علم فاعله. و 》التفاوته هو الاختلاف الواقع على غير سنن، وهو دال على جهل فاعله 102.

\section{أكل وافترس}

״الافتراس" معناه في فعل السبع: القتل فحسب، وأصل الفرس: دق العنق، وإخوة يوسف إنما أدَّعوا على ألى

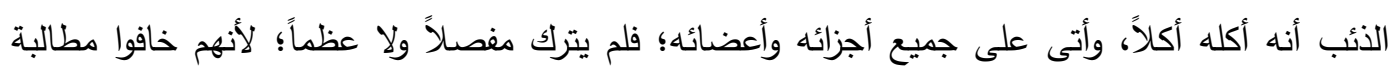
أبيهم إياهم بأثر باق منه يشهر بصحة ما زعموه؛ فادعوا فيه الأكل ليزيلوا عن أنفسهم الإحراج بالمطالبة؛

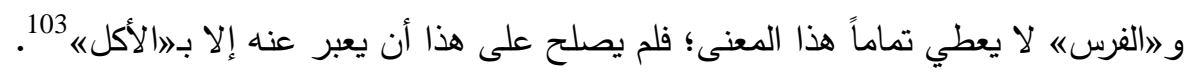

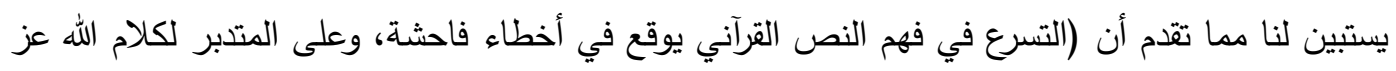

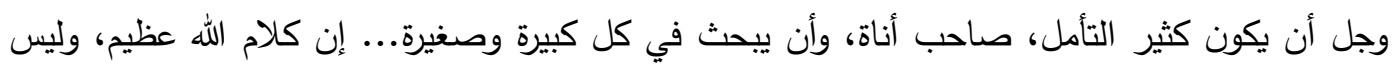

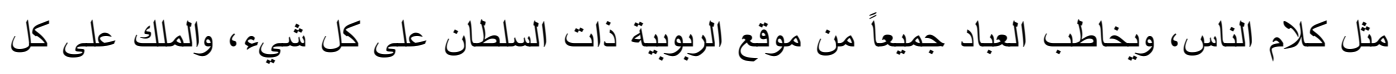
شيء، والقدرة على كل شيء. إن كل حرف، وكل كلمة، وكل فكرة... مختارة فيه بعناية عظيمة، وإتقان بديع، ومن قصر فهمه عن إدراك دلالات كتاب الله سبحانه وتعالى؛ فهو يجازف بقذف تفعيرات تبادرت إلى وكلى

$$
\begin{aligned}
& 101
\end{aligned}
$$

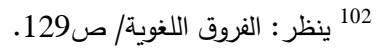

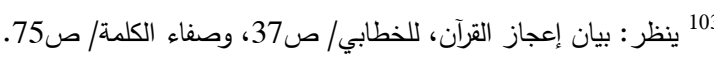

\section{IJHER}

International Journal of Humanities and Educational Research

Volume 2, Issue 4, December 2020, p.61-93 
ذهنه، وإذا طرحها على سبيل الاحتمال؛ فلا يجزم بها! إن كتاب الله عظيم، وذو دلالات ذوات عمق،

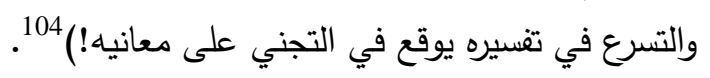

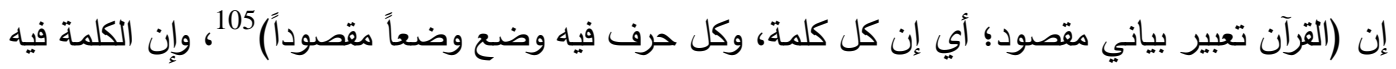
أشبه بالعضو في جسم الإنسان وهو يؤدي وظيفته حين يكون في موضعه، فإذا زايله إلى موضع إنى آخر ؛ تغير حال الجسم، واُعتل، واُختل توازنه! بهذا المقياس الحكيم، والقسطاس المستقيم كانت كلمات التهن القرآن الكريم طبقاً لمعانيه؛ بحيث أسترعت ألفاظه وفصاحته أنظار العلماء

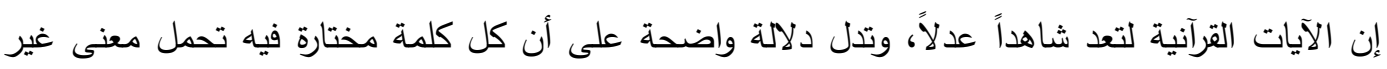

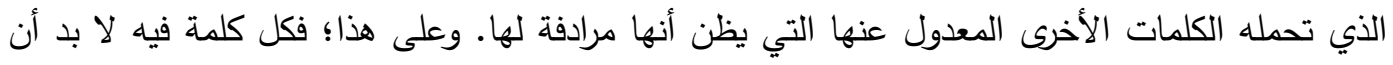

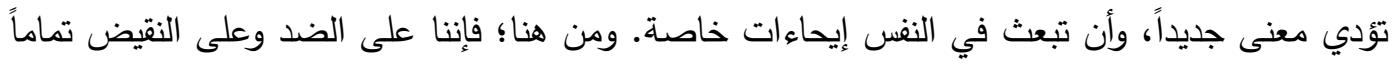
مما جرت به عادة بعض أرباب المعاجم وكثير من أهل اللغة والتفسير من بيان معاني الألفاظ القرآنية

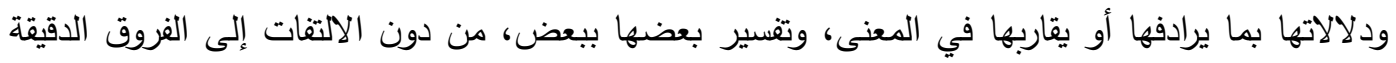

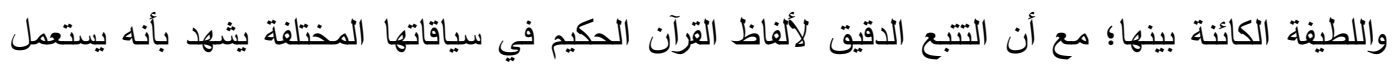

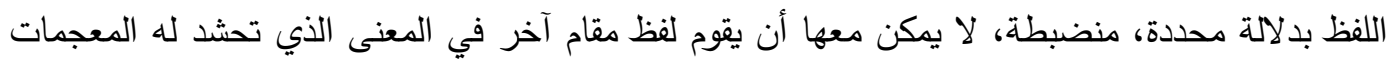

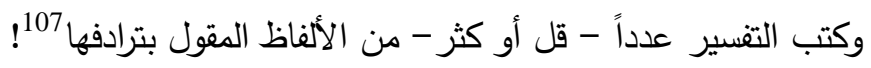

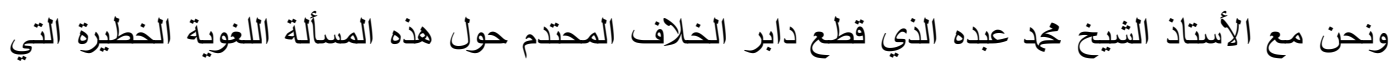
تشعبت فيها آراء العلماء وتداخلت! يقول: (وأنا لا أجيز لمسلم أن يقول في نفساد أو بلسانه: إن في القرآن

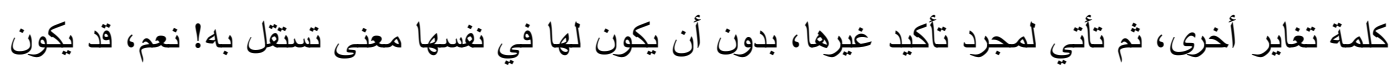

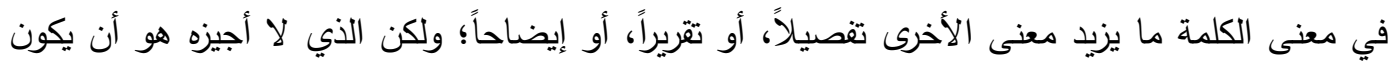

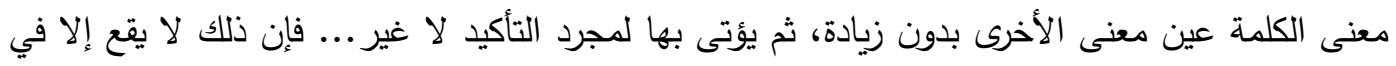

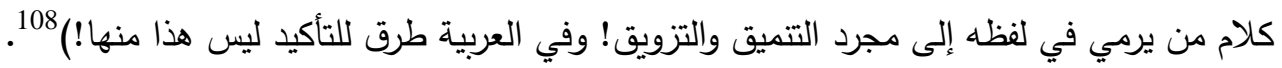
إن ما جرت به عادة بعض أرباب المعاجم وكثير من أهل اللغة والتفسير من بيان معاني الألفاظ القرآنية

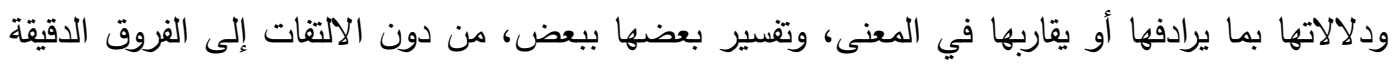

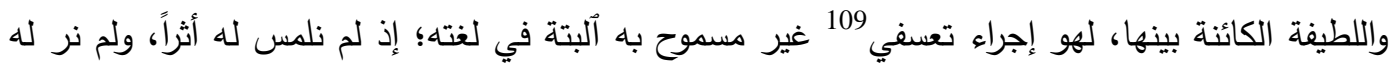

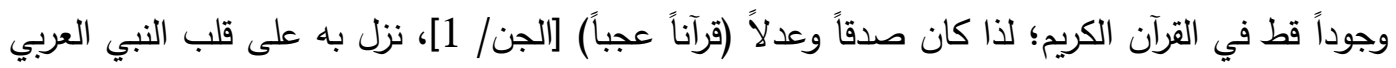

$$
\begin{aligned}
& 104 \text { قواعد التدبر الأمثل لكتاب الله عز وجل/ ص348. }
\end{aligned}
$$

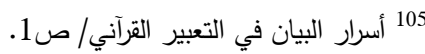

$$
\begin{aligned}
& 106 \text { ينظر : صفاء الكلمة/ ص240. } \\
& 107 \\
& 108 \text { تفسير المنار (107 بنظر : 39)، بتصرف طفيف. }
\end{aligned}
$$

109 يقال: عسف فلان في الأمر؛ بمعنى: فعله من دون روية ولا تدبر ولا سبر لأبعاده. ويقال: تعسف فلان في الكلام؛ إذا حمله على معنى لا

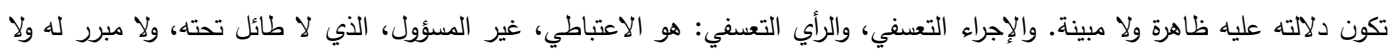

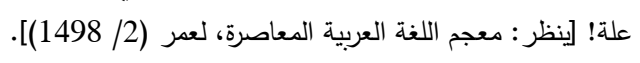

\section{IJHER}

International Journal of Humanities and Educational Research

Volume 2, Issue 4, December 2020, p.61-93 
الأمي الكريم الروحُ الأمينُ (بلسان عربي مبين) [الثعراء/ 195]، وكان - حقاً ويقيناً - (دقيقاً في اُختيار

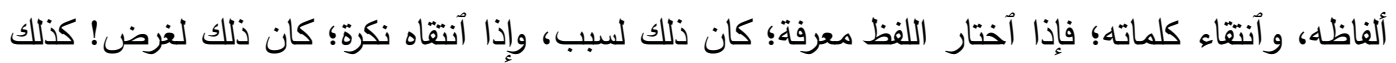
إذا كان اللفظ مفرداً؛ كان ذلك لمقتضيً يطلبه، وإذا كان مجموعاً؛ كان لحال يناسبه! وقد يختار الكلمة ويهمل مرادفها الذي يشترك معها في الدلالة، وقد يفضل كلمة على أخرى والكلمتان بمعنى واحد، وربما ولنان يتخطى في التعبير المسن اللفظي والجمال البديعي - على قدره وحسنه - لغرض أسمى - وهو المحسن

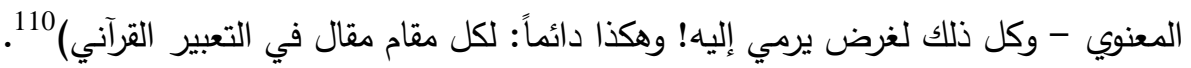

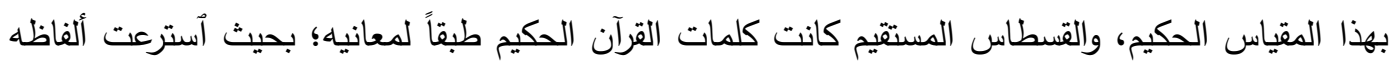

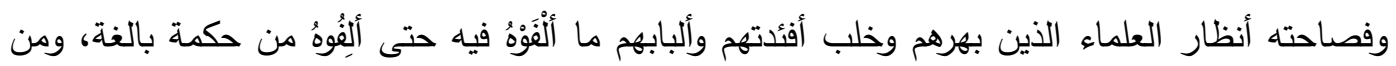
دقة متتاهية، ومن أنه قد تحرى في ألفاظه وتعبيراته كل ما هو أحق بالذكر ، وأولى بالاستعمال، ودعا إلى لى

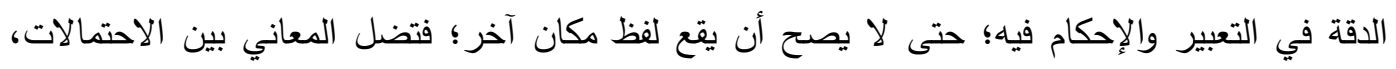

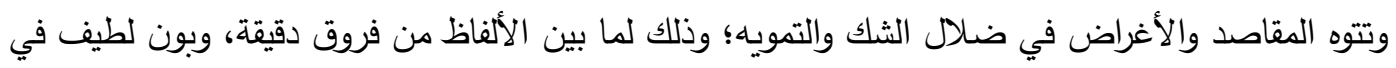

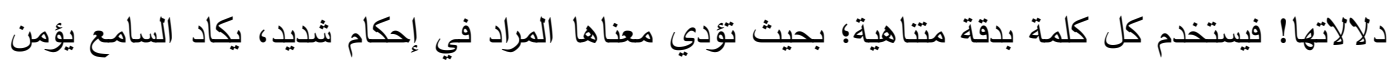

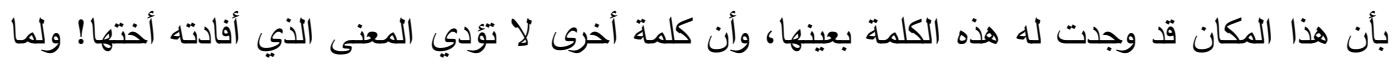

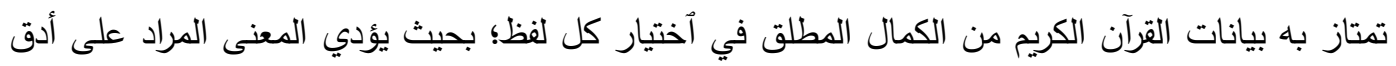

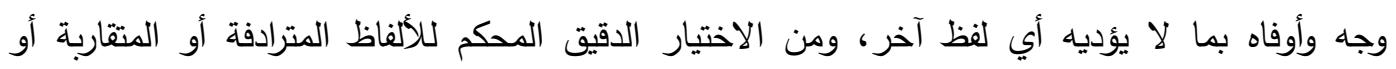

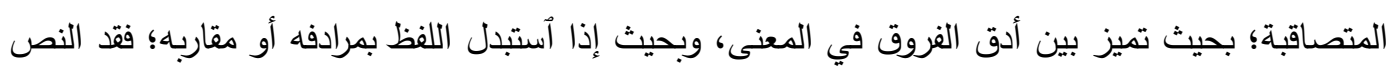

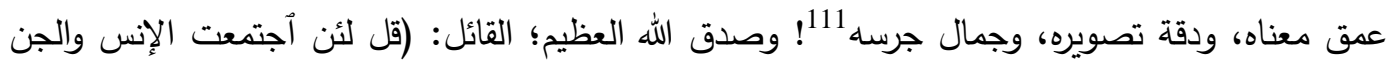

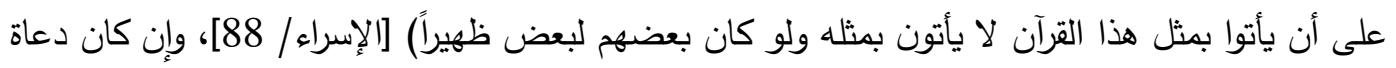

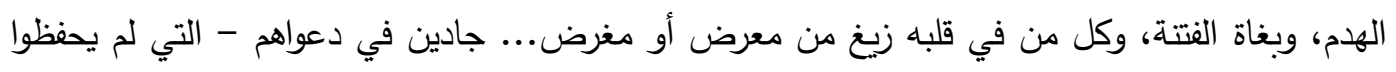

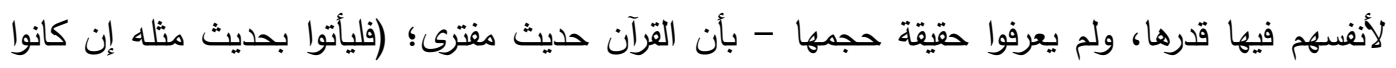

صادقين) [الطور / 34]

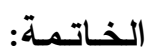

1. من دقائق التركيب وأسس البلاغة في القرآن الكريم: وضع كل نوع من الألفاظ التي تثتمل عليها

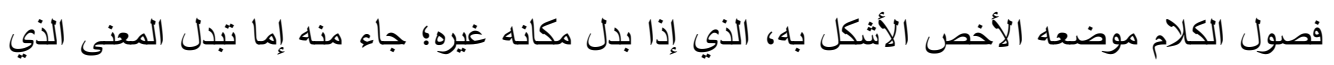
يكون منه فساد الكلام، وإما ذهاب الرونق الذي يكون معه سقوط البلاغة؛ ذلك أن في الكلام ألفاظاً

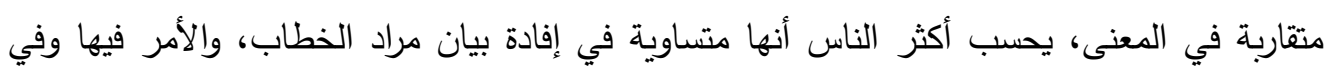

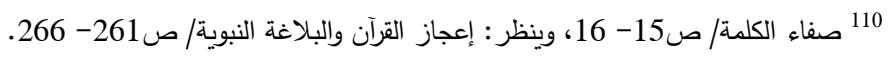

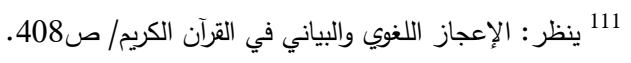

\section{IJHER}

International Journal of Humanities and Educational Research

Volume 2, Issue 4, December 2020, p.61-93 
ترتيبها عند جمع من علماء اللغة بخلاف ذلك؛ لأن لكل لفظة منها خاصية تتميز بها عن صاحبتها في بعض معانيها، وإن كانا قد يشتركان في بعضها الآخر . 2. القرآن تعبير بياني مقصود؛ أي إن كل كلمة، وكل حرف فيه وضع وضعان وضعاً مقصوداً، فإذا ما حاولنا

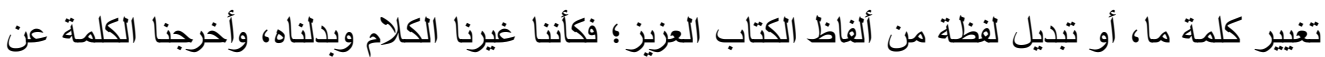
صفة الفصاحة، ودلائل الإعجاز ، وأسرار البلاغة، وجردناها من زينة الأسلوب وأسلوب الزينة، وحجبنا

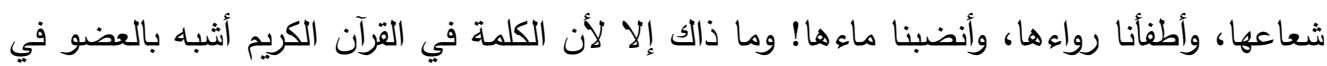

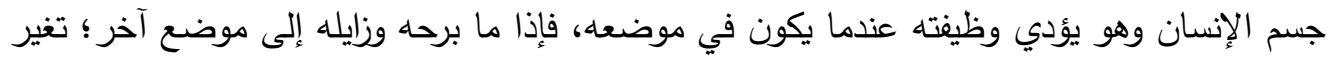
حال الجسم، وأعتل كيانه، واُختل توازنه! 3. تحرى القرآن الحكيم في ألفاظه وتعبيراته كل ما هو أحق بالذكر ، وأولى بالاستعمال، ودعا إلى الدقة

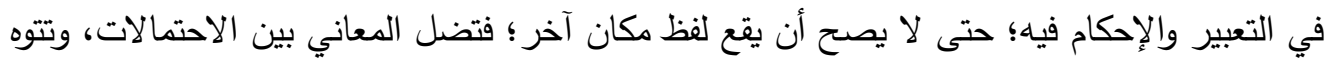
المقاصد والأغراض في ضلال الثك والتمويه؛ فهو ينتقي ألفاظه، ويختار كلماته؛ لما بين الألفاظ من الأن التان

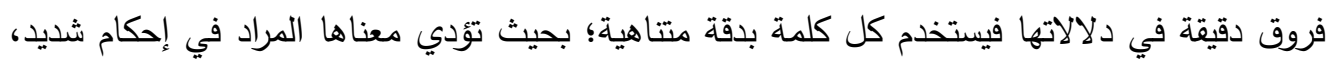

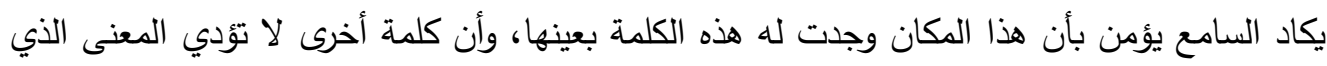

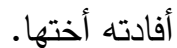

4. أستعمل القرآن الكلمة في موقعها المحدد الذي لا تغني فيه غيرها؛ بحيث لو نزعت كلمة منه أو أزيلت

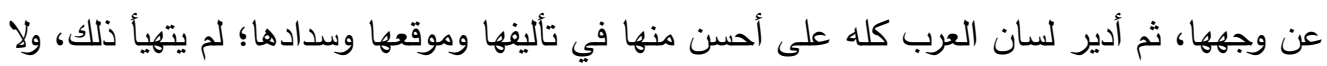
أتسعت له اللغة بكلمة واحدة! 5. كان القرآن دقيقاً في اُختيار ألفاظه، وآنتقاء كلماته؛ فإذا أختار اللفظ معرفة؛ كان ذلك لسبب، وإذا أنتقاه نكرة؛ كان ذلك لغرض! كذلك إذا كان اللفظ مفرداً؛ كان ذلك لمقتضى يطلبه، وإذا كان مجموعاً؛

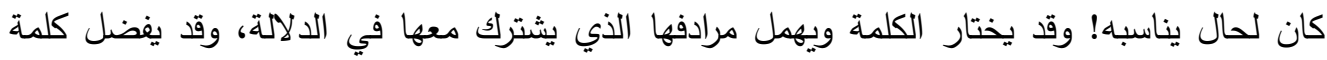

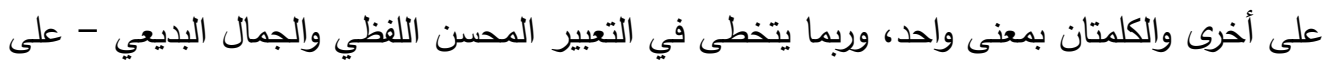
قدره وحسنه - لغرض أسمى - وهو المحسن المعنوي - وكل ذلك لغرض يرمي إليه! وهكذا دائماً: لكل مقام مقال في التعبير القرآني. 6. يختار القرآن الحكيم الكلمة قاصداً لفظها ومعناها معاً، وكل كلمة فيه شاهد على ذلك؛ إذ وضعت كل

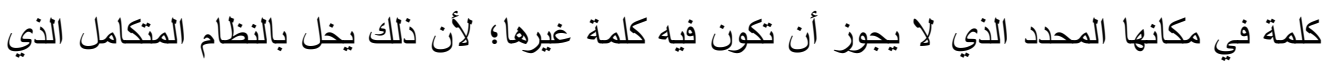

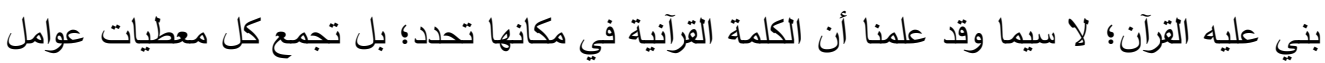
السياق المختلفة في إظهار الدالالة. 7. قد يأتي في القرآن آختيار كلمة في موضع، ثم قد يأتي اُختيار مرادف لها في موضع آخر ، أو أختيار

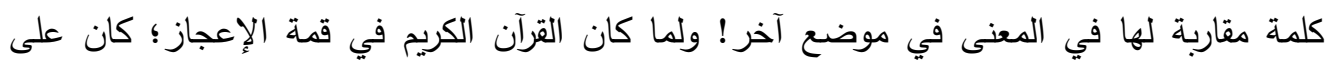

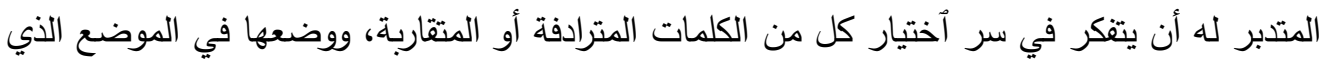

\section{IJHER}

International Journal of Humanities and Educational Research Volume 2, Issue 4, December 2020, p.61-93 
أستعملت فيه دون الأخرى؛ فمن شأن التفكر والبحث أن يهدي بعض المتفكرين الباحثين إلى سر ذلك؛

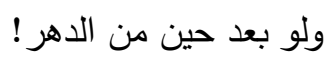

8. مهما أمكن إبعاد فكرة 》الترادف《 عن الكلمات القرآنية؛ فهو الأحق بأن يكون المنهج لدى تدبر القرآن

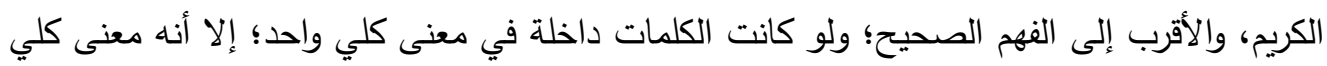
عام صالح لنسب متفاوتة، وبإبعاد فكرة 》الترادف) قد يكثف المتدبر لكتاب الله المستويات النسبية

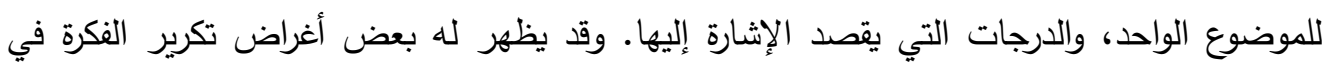
مواضع مختلفة.

9. للتركيب والسياق اللغوي أثر ماض في أستحداث معان جديدة وتخليقها، وتفجير طاقات دلالية كامنة،

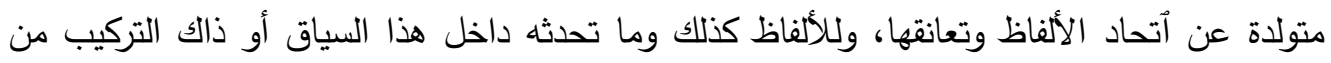

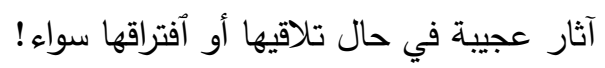
10. المعنى الواحد في القرآن الكريم يؤديه لفظ واحد، فإذا تعددت المعاني؛ كان ذلك مدعاة إلى تعدد الألفاظ إزاءها؛ فقد يتغير في الآية القرآنية لفظ من سياق إلى سياق، ومن سون سورة إلى سورة إذا ما دعت الحاجة

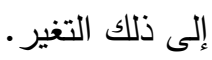
11. كلما آجتمعت الكلمات العربية التوائم في العبارة؛ أفترقت في المعنى، وكلما أفترقت في العبارة؛ أجتمعت أو مالت إلى الاجتماع أو التقارب في المعنى بقدر الإمكان! 12. جرت عادة بعض أرباب المعاجم وكثير من أهل اللغة والتفسير من بيان معاني الألفاظ ودلالاتها بما

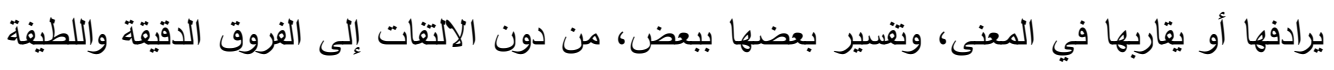

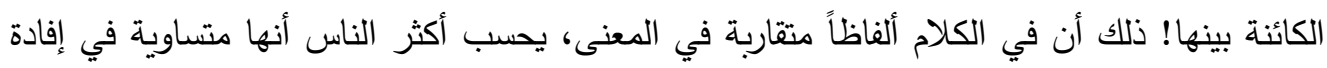
بيان مراد الخطاب. والأمر فيها وفي ترتيبها عند بعض علماء اللغة بخلاف ذلك؛ لأن لكل لفظة منها خاصية تتميز بها عن صاحبتها في بعض معانيها، وإن كانا قد يشتركان في بعضهاء وفي الآخر .

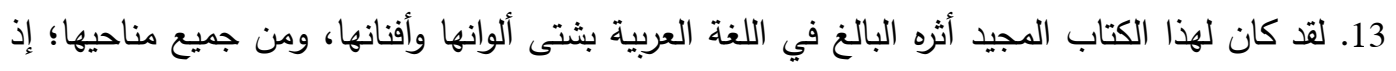
إنه صفى هذه اللغة؛ فأثاع في الاستعمال أصفى ألفاظها جرساً، وأدقها تعبيراً، وأحلاها نغماً، وأورد كل لفظة في مكانها المناسب ببراعة فائقة، وآلتزم الدقة في مراعاة دلالة الألفاظ، وإيرادها مواردها بطريقة تعجز عنها الخلائق. 14. إن كلام الله عظيم، وليس مثل كلام الناس، ويخاطب العباد جميعاً من موقع الربوبية ذات السلطان على كل شيء، والملك على كل شيء، والقدرة على كل شيء. وإن كل حرف، وكل كلمة، وكل فكرة

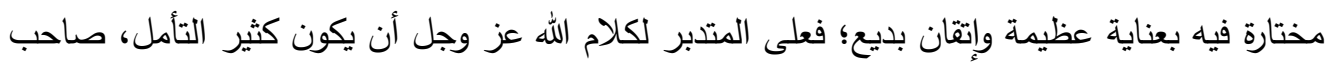

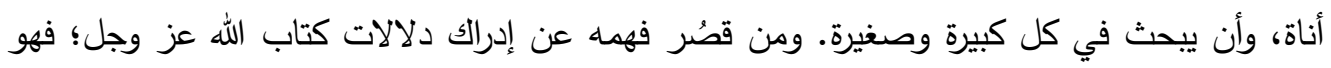

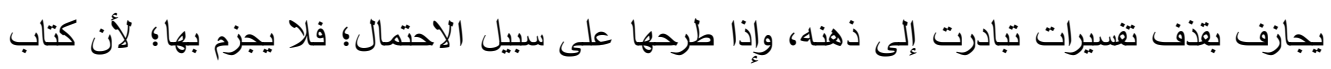

\section{IJHER}


الله عظيم، وذو دلالات ذوات عمق، والتسرع في تفسيره يوقع في التجني على معانيه، ويفضي إلى

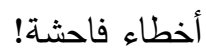

15. من أخطر وسائل التجهيل المعار: تعدد الغموض في المعاني، وفي دلالات الألفاظ المستخدمة في

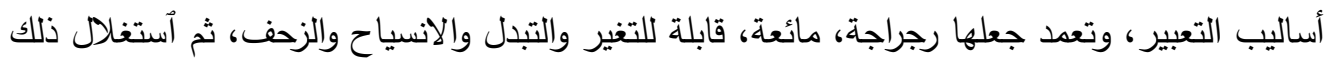
بمكر عند الرغبة بالتضليل! بخلاف منهج الإسلام القائم على تحديد المعاني، وتحديد دلالات

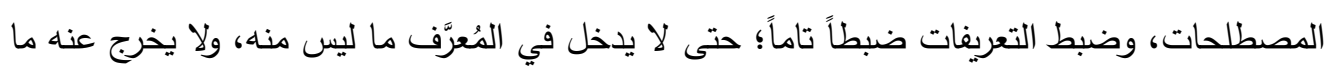

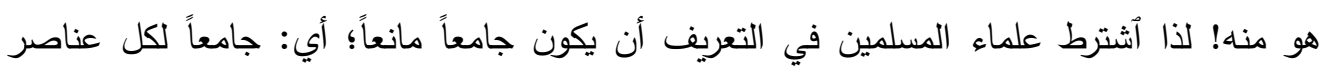
المُعرَّف داخل التعريف، مانعاً من دخول ما ليس منه فيه. يستغل المضللون - عن طريق لعبة ذكاء

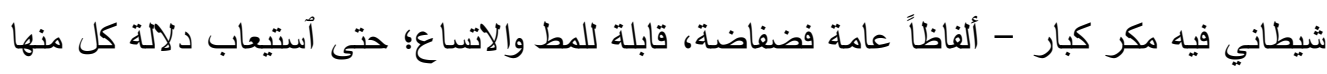
لأمور متخالفة ومتضادة، ومتتاقضة أحياناً!.

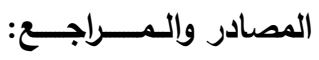

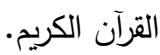

أبحاث ونصوص في فقه اللغة العربية: أ.د.رشيد عبدالرحمن العبيدي (تربنه 1428هـ/ 2007م)، مطابع التعليم

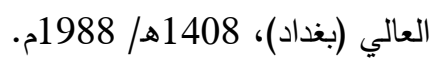

الإتقان في علوم القرآن: أبو الفضل جلال الدين عبدالرحمن بن أبي بكر السيوطي (ت911هـ)، دار الإيمان

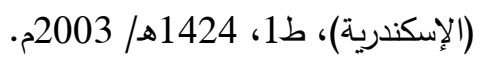

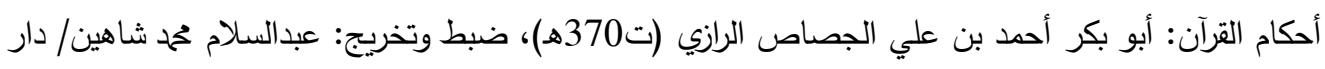

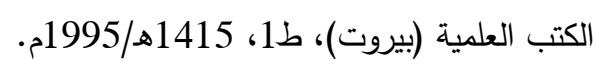

الأسئلة والأجوبة المفيدة في لطائف بعض الآبرو، طآيات القرآنية: أ.د.فاضل صالح السامرائي/ موقع المكتبة الثاملة على شبكة الإنترنت.

أسرار البيان في التعبير القرآني: أ.د.فاضل صالح السامرائي/ موقع الدكتبة الثاملة على شبكة الإنترنت.

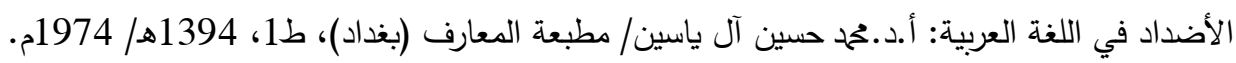

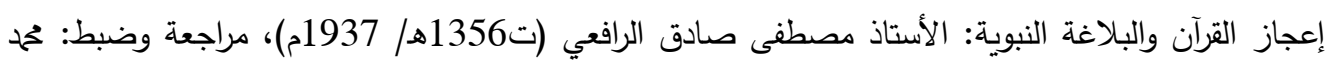

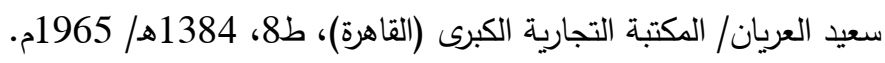
الإعجاز اللغوي في القصة القرآنية: د.محمود السيد حسن مصطفى (أصل هذا الكتاب رسالة ماجستير، بإشراف التهاف

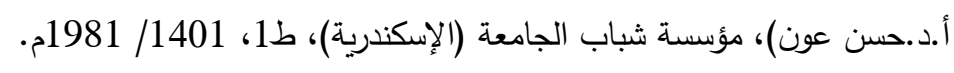

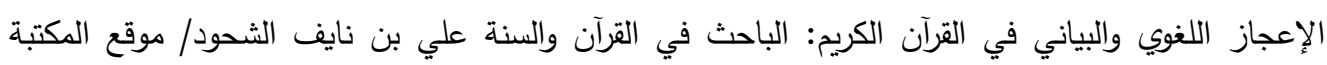
الشاملة على شبكة الإنترنت.

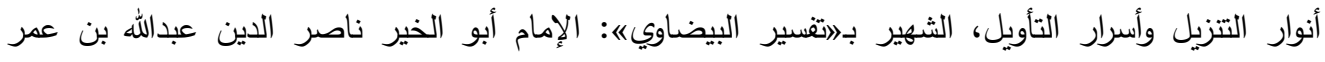

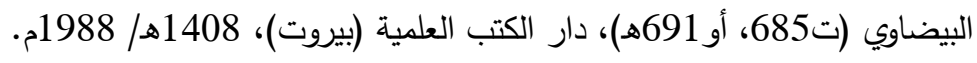

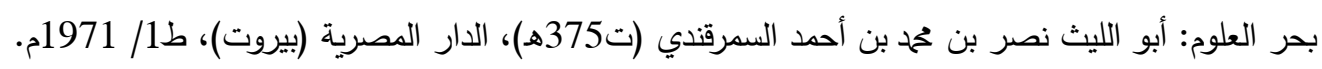

\section{IJHER}

International Journal of Humanities and Educational Research

Volume 2, Issue 4, December 2020, p.61-93 
بحوث في المعمية العربية - المعجم اللغوي: أ.د.عبدالله الجبوري/ الهجع العلمي العراقي، 1425هـ/ 2004 البرهان في علوم القرآن: أبو عبدالله بدر الدين تحمح بن محمد بن بهادر بن عبدالله الزركثي (ت794هـ)، تقديم

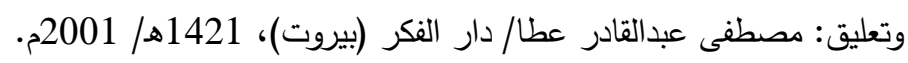

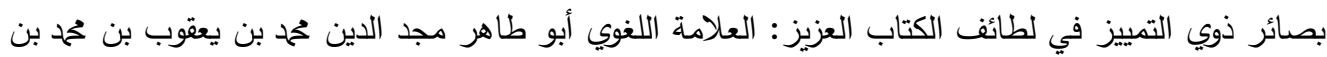

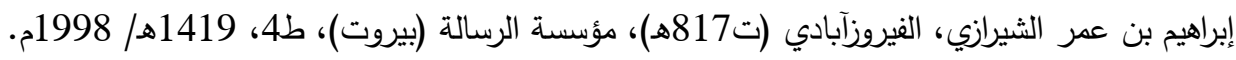

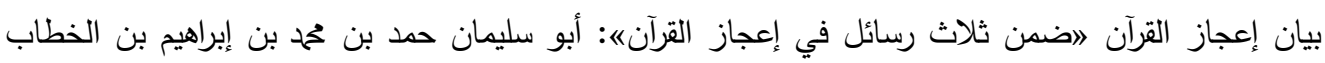

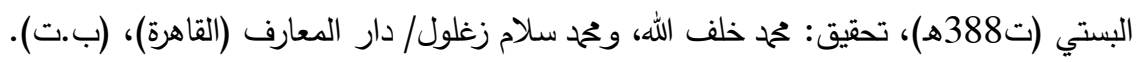

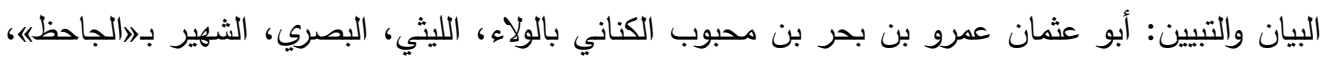

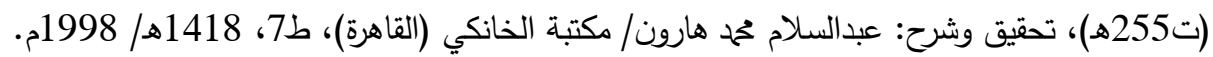
تاريخ علوم اللغة العربية: الأستاذ طه بن صالح الفضيل الراوي (ت1365هـ 1365ه 1946م)، مطبعة الرشيد (بغداد)،

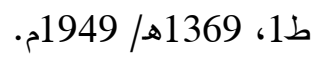
التطور الدلالي بين لغة الثعر الجاهلي ولغة القرآن الكريم - دراسة دلالية مقارنة: عودة خليل أبو عودة/ مكتبة

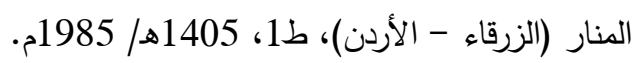

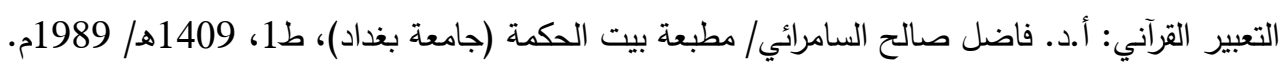

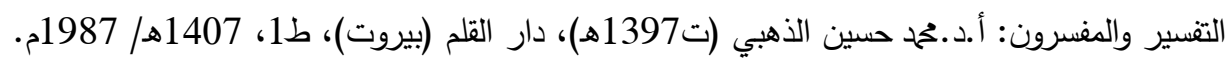

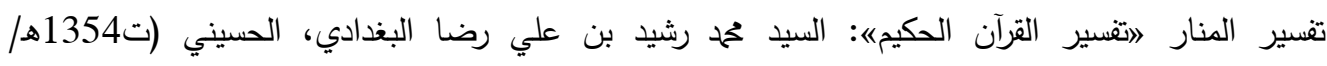

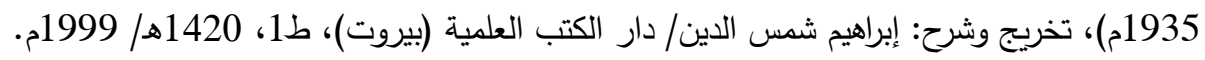

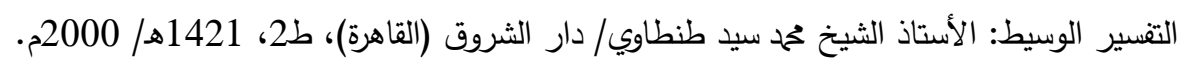

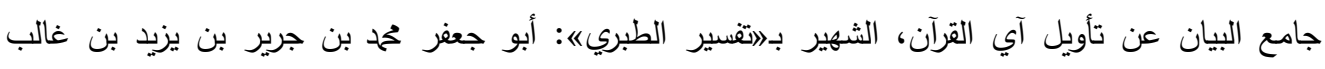

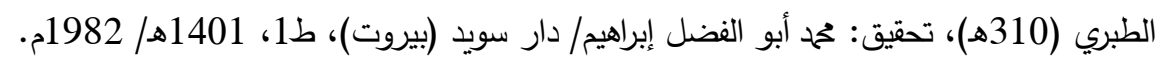

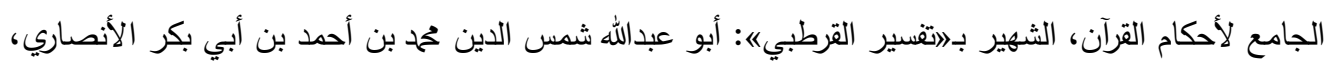

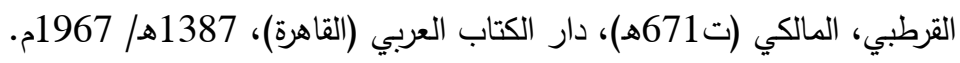
جرس الألفاظ ودلالتها في البحث البلاغي والنقدي عند العرب: أ.د.ماهر مهدي هلال/ دار الحرية (بغداد)،

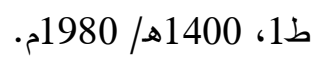

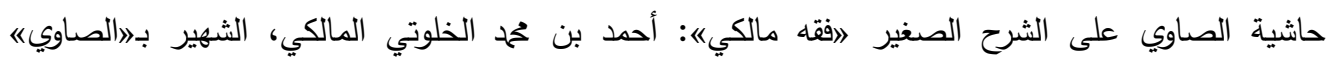
(ت1241هـ)، موقع الإسلام على شبكة الإنترنت. الخصائص: أبو الفتح عثمان بن جني الموصلي، النحوي (ت3924هـ)، تحقيق: الثيخ حمح علي النجار / دار

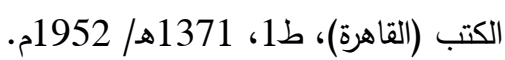

دراسات في فقه اللغة: أ.د.صبحي الصالح (ت1407هـ/ 1407 1987م)، دار العلم للملايين (بيروت)، ط137 ال،

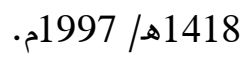
درَّة الغوَّاص في أوهام الخواصِّ: أبو محمد القاسم بن علي بن محمد بن عثمان الحريري، البصري (ت516هـ)،

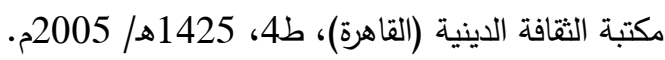

\section{IJHER}

International Journal of Humanities and Educational Research

Volume 2, Issue 4, December 2020, p.61-93 
دلالة الألفاظ: أ.د.إبراهيم أنيس/ مطبعة أبناء وهبة حسان (القاهرة)، ط1، 1397هـ/ 1977م.

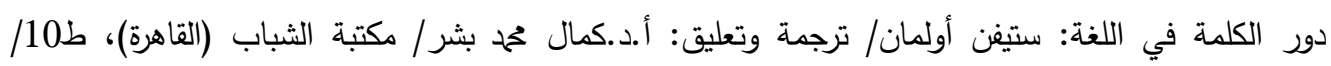
1986 الرسالة: الإمام أبو عبدالله محمد بن إدريس بن العباس بن عثمان بن شافع القرشي (ت204هـ)، تحقيق: الأستاذ

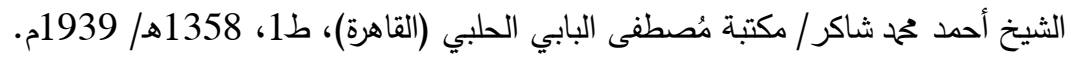

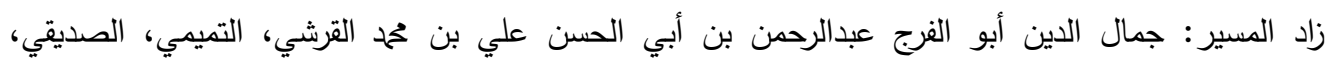

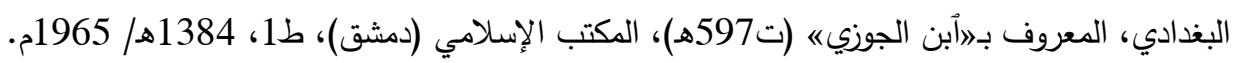

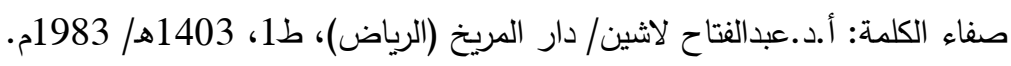

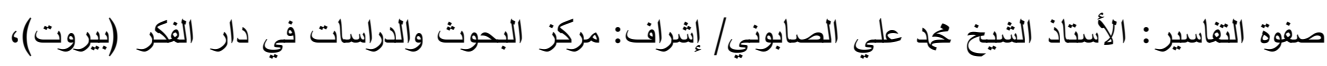

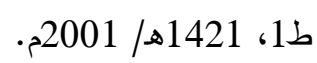
العربية والبحث اللغوي المعاصر : أ.د.رشيد عبدالرحمن العبيدي (ت1428هـ/ 2007م)، مطبعة المجمع العلمي

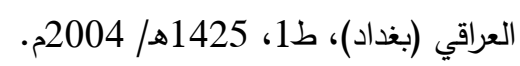
علم أصول الفقه: الشيخ عبدالوهاب بن عبدالواحد خلاف (ت1325)، 1375هـ/1956م)، دار الإيمان (الإسكندرية)، ط1، 1424هـ/ 2003م. علم اللغة: أ.د.حاتم صالح الضامن/ كلية الآداب - جامعة بغداد (قسم اللغة العربية)، ط1، 1409هـ/ 1989م.

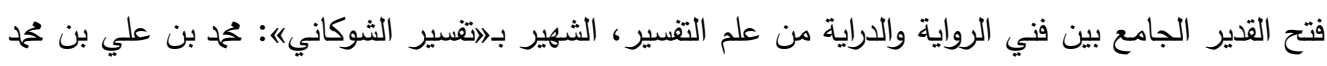

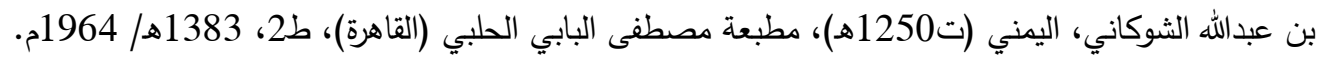
الفروق اللغوية: أبو هلال الحسن بن عبدالله بن سهل بن سعيد بن يحيى بن مهران اللغوي، العسكري

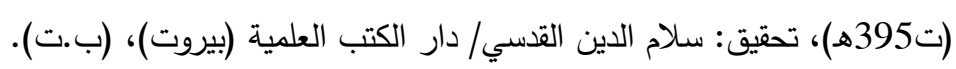
الفروق اللغوية وأثرها في تفسير القرآن الكريم: أ.د.محم بن عبدالرحمن الثايع/ مكتبة العبيكان (الرياض)، ط1، الفين، 1414هـ/ 1993م الفرونة فصول في فقه العربية: أ.د.رمضان عبدالتواب/ دار الجيل (القاهرة)، ط2، 1400هـ/ الدها 1410 1980م.

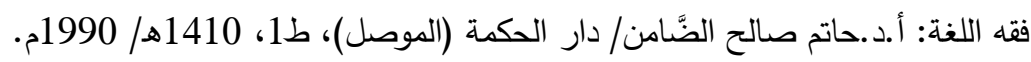

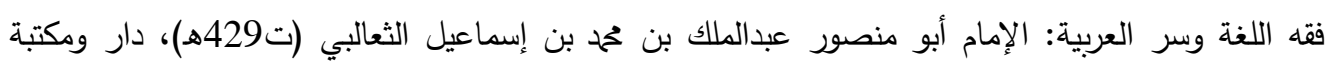

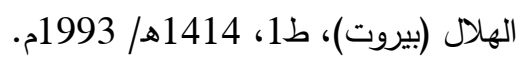
في اللهجات العربية: أ. د. إبراهيم أنيس/ المطبعة الفنية الحديثة (القاهرة)، ط4، 1493 1393ه/ 1973م.

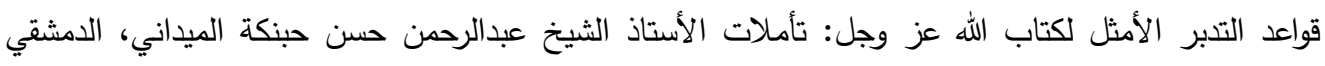

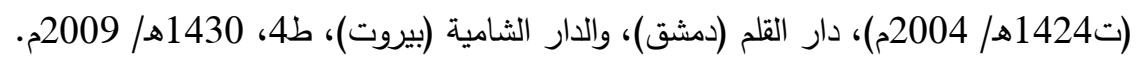

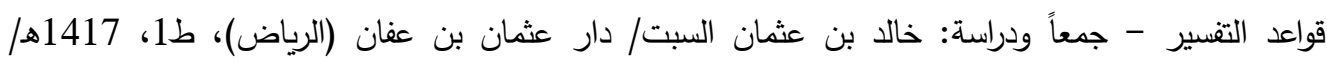
1997 كتاب العربية الأكبر: أ.د.عائشة محم علي عبدالرحمن، المعروفة بابنت الشاطئه (ت1419هـ/ 1999م)،

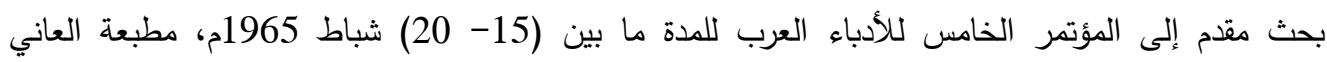

\section{IJHER}

International Journal of Humanities and Educational Research

Volume 2, Issue 4, December 2020, p.61-93 
الكثاف عن حقائق التنزيل وعيون الأقاويل في وجوه التأويل، الثهير بهاتقسير الزمخشريه: أبو القاسم جار الله

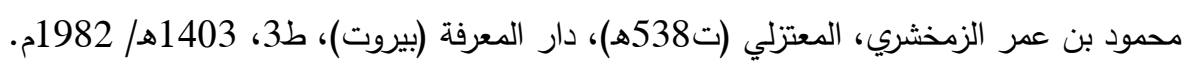

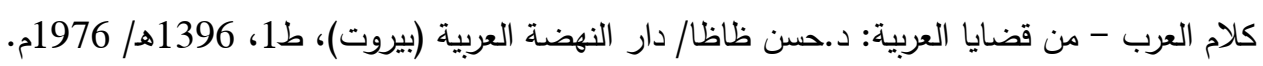

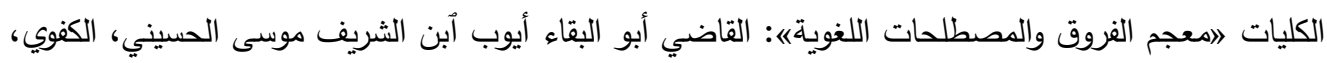

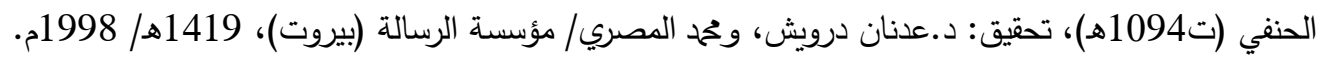
كواشف زيوف في المذاهب الفكرية المعاصرة: الأستاذ الثيخ عبدالرحمن حسن دينان دبنكة الميداني، الدمشقي

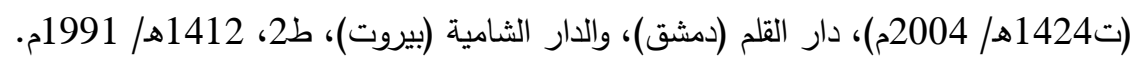

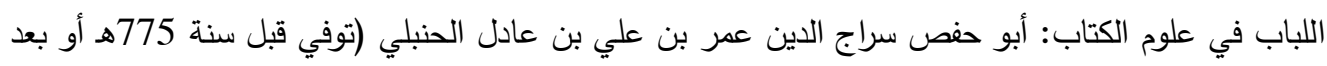

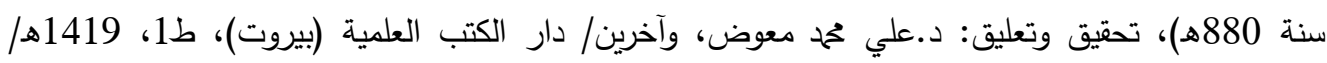
1998 م. لسان العرب: أبو الفضل جمال الدين محم بن مكرم بن علي بن منظور الأنصاري، الإفريقي، المصري

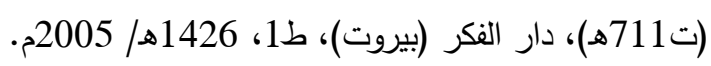

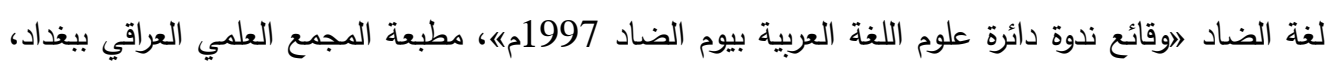
1418هـ/ 1998م.

اللغة العربية ومكانتها بين اللغات: أ.د.فرحان السليم/ موقع المكتبة الثاملة على شبكة الإنترنت.

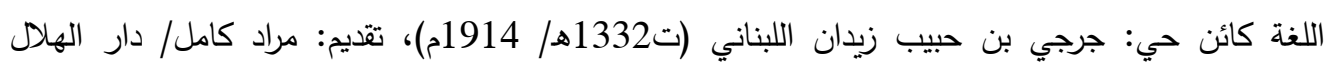

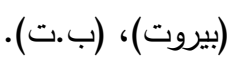

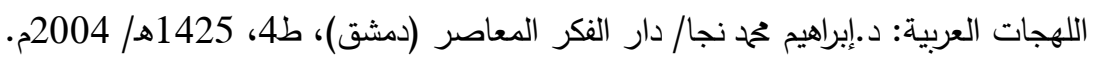

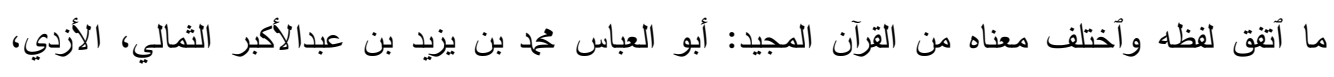

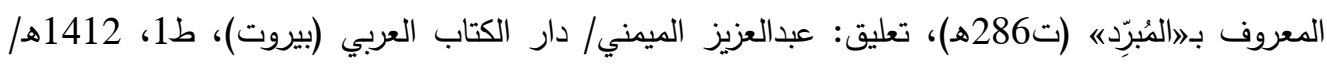
1991

مباحث في علوم القرآن: الدكتور الثيخ مناع بن خليل القطان/ مكتبة المعارف (بيروت)، ط3، 1421هـ/ 2000 المزهر في علوم اللغة وأنواعها: أبو الفضل جلال الدين عبدالرحمن بن أبي بكر السيوطي، الثافعي، الدصري

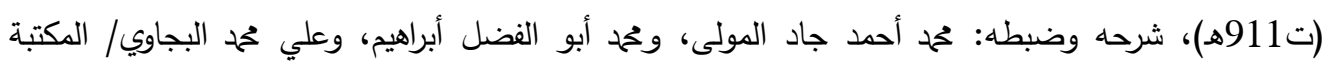

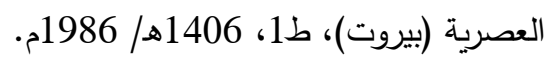

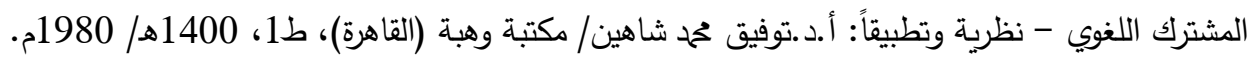

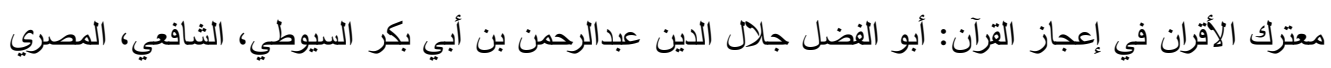

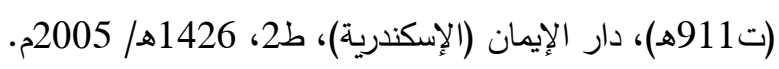

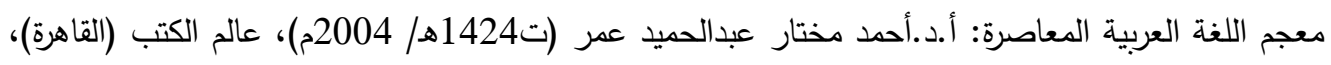
ط1، 1429هـ/ 2008م.

\section{IJHER}

International Journal of Humanities and Educational Research

Volume 2, Issue 4, December 2020, p.61-93 


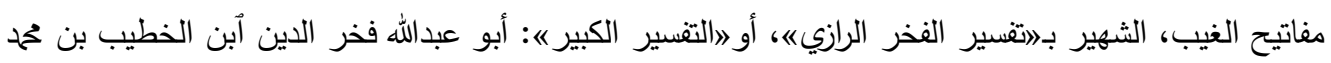

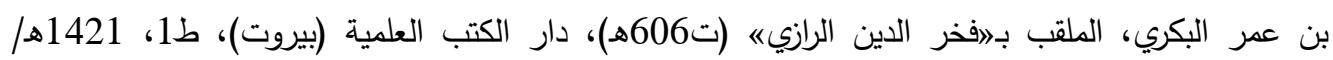
2000

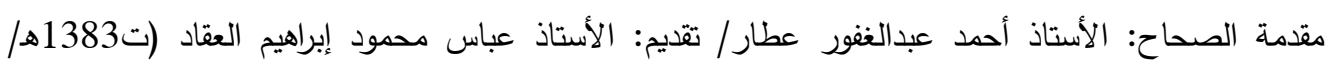

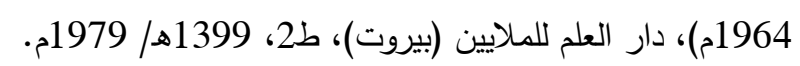

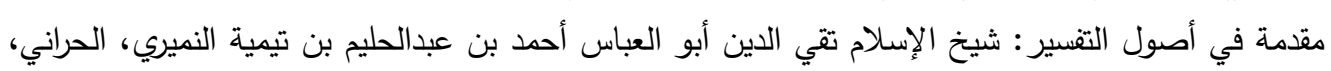

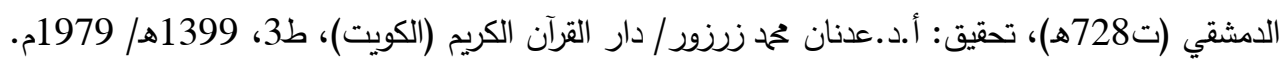

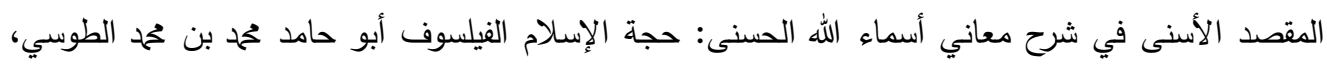

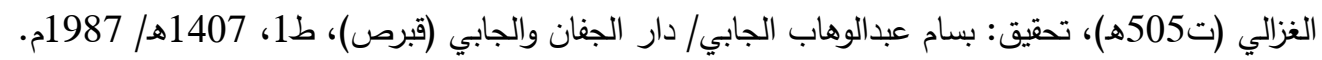

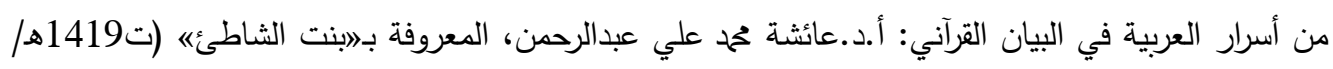

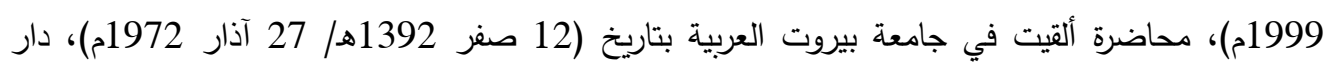
الأحد البحتري إخوان (بيروت)، (ب.ت).

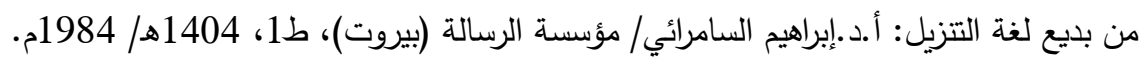

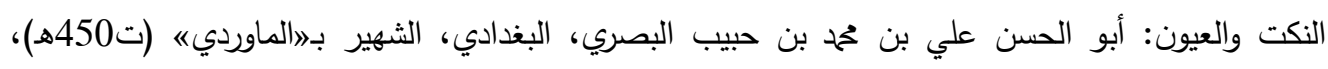

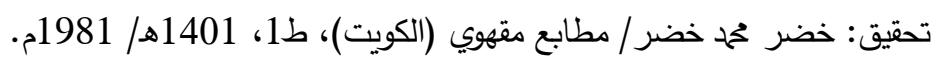

